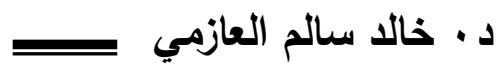

\title{
اجتماع المال الحلال بالحرام والتحلل منه وفق القواعد الفقهية
}

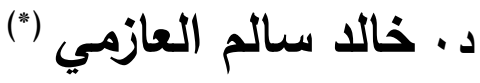

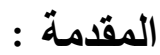

إنَّ الحمد لله نحمده، ونستعينه، ونستغفره، ونستهديه، ونعوذ باله من شرور

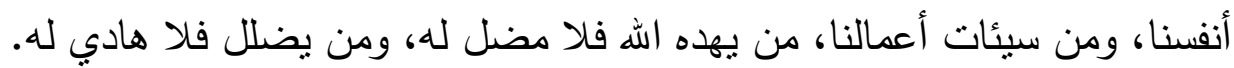

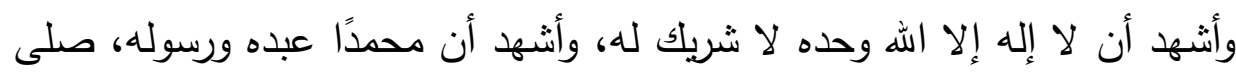
اله عليه وعلى آله وصحبه أجمعين. أمَّا بعد:

فحب المال فطرة فطر الله الناس عليها، وهو إحدى ضروريات الحياة؛ لذا شرع اللهُ وسائل مباحة لكسبه وتحصيله، وحرم وسائل أخرى في كسبه وتحصيله،

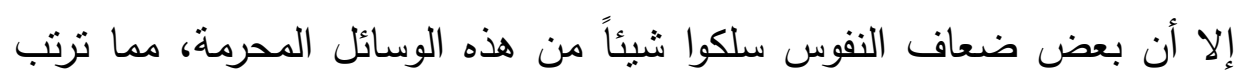
عليه كسب شيء من الأموال المحرمة، ثم يمنّ الله عليهم بالتوبة والإنابة إليه، فيسعون إلى البحث عن الوسائل التي يتحللون بها من هذا المال الحرام، وكيف بلف التهال يكون هذا التحلل، لا سيما في هذا العصر الذي تنتوعت فيه لئل وسائل كسب المال

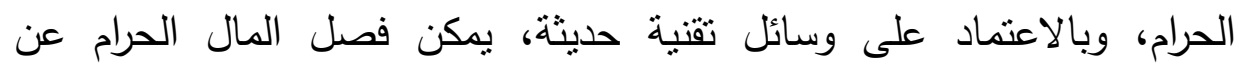
الحلال، فجاءت فكرة هذه الدراسة بعنوان (اجتماع المال الحلال بالحرام والتحلل منه وفق القواعد الفقهية). ذللك أن علم القواعد الفقهية له مكانة راسخة بين العلوم الثرعية، ولا شك ولا ريب بأن تنزيل الحوادث المستجدة إنما يكون على القواعد الفقهية ومقاصد الثريعة، إذ التأمل في هذين الأمرين يعين ويرشد الفقيه إلى الحكم الثرعي الثيان 


\section{اجتماع المال الحلال بالحرام}

للحادثة. قال الإمام الثافعي: اهليس نتزل بأحد من أهل دين الله نازلة إلا وفي

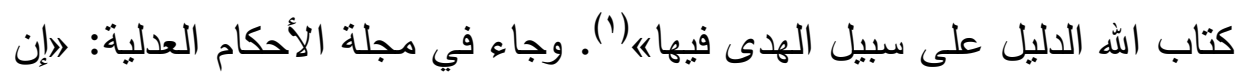

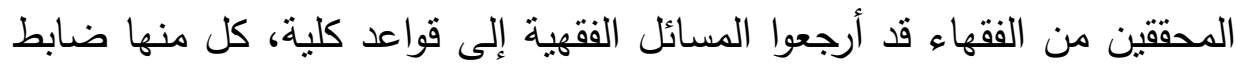

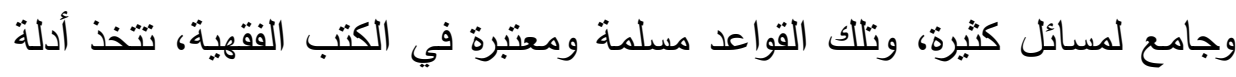
لإثبات المسائل وتفههها في بادي الأمر ، فذكرها يوجب الاستئناس، ويكون وسيلة

$$
\text { أولاً: مشكلة البحث: في الأذهانه (؟). }
$$

يمكن تحديد مشكلة الدراسة فيما يلي: لئه

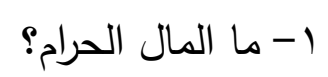

r- ما مفهوم قاعدة (إذا اجتمع الحلال والحرام غلب الحرام)؟ r- كيف يتم التحلل من المال الحرام في ضوء التعاء القاعدة الفقهية السابقة؟ ثانياً: أهمية البحث:

$$
\text { تتبع أهمية البحث من النقاط الآتية: البح: }
$$

1- انتشار المال الحارم وتعدد وسائل كسبه، مما جعله ظاهرة في المجتمعات الهات

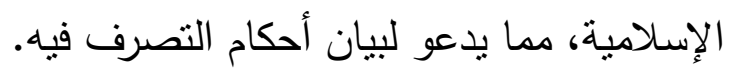

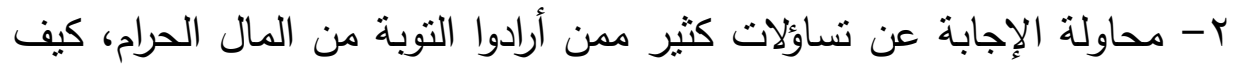

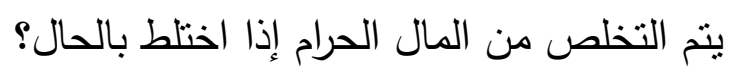

r- بيان الدور الكبير للقواعد الفقهية في استتباط الأحكام الثرعية لا سيما ما لألمال

$$
\text { ثالثاً: أهداف البحث: بالمستدات منها. }
$$

$$
\text { يهذف هذا البحث إلى ما يلي: }
$$

1- بيان معنى المال الحرام، وتوضيح بعض وسائل كسبه.

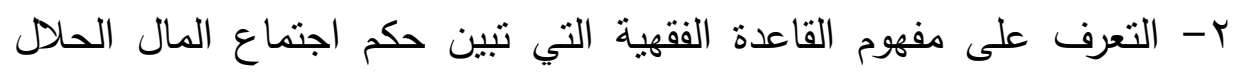

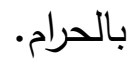


د. · خالا سالم العازمي

r- بيان أثز القواعد الفقهية في التحلل من المال الحرام إذا اجتمع بالحلا، وكيفية ذللك.

رابعاً: الدراسات السابقة:

وجدت عددًا من الدراسات السابقة التي خدمت جوانب من هذا الموضوع، وقد تتوعت هذه الدراسات ما بين رسائل علمية وكتب شرعية ومن أهم الدراسات والكتب التي لها صلة بالموضوع ما بأتي: 1 - دراسة يحيى موسى حمد بني عبدالله، بعنوان: "القواعد الفقهية في اجتماع الحلال والحرام وتطبيقاتها المعاصرة"، رسالة دكتوراه في الفقه وأصوله، الجامعة الأردنية،

$$
\text { كلية الدراسات العليا، آيار ع ـ . . rم. }
$$

r-دراسة أحمد محمد السراج، بعنوان: "قاعدة: إذا اجتمع الحلال والحرام غلب

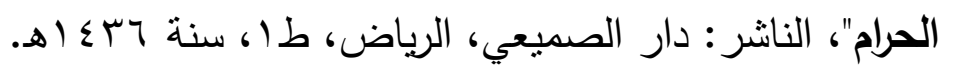
r-دراسة صالح اليوسف، بعنوان: "قاعدة: إذا اجتمع الحلال والحرام غلب الحرام"، الناشر : مركز البحوث في كلية الثربعة والدراسات الإسلامية، جامعة القصيم، السعودية. ع - عباس أحمد الباز ، بعنوان: "المال المحرم وضوابط الاتتقاع والتصرف به في الفقه الإسدلامي"، رسالة ماجستير، الجامعة الأردنية، عمان، سنة 7 إع (اه. وطبعت الرسالة باسم: أحكام المال الحرام وضوابط الاثتفاع والتصرف به في الفقه

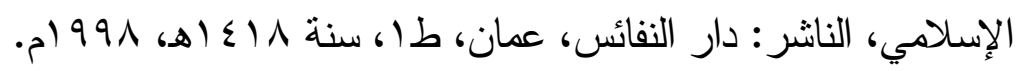
ه- دراسة طارق بن محمد الخويطر ، بعنوان: "المال المأخوذ ظلماً وما يجب فيه

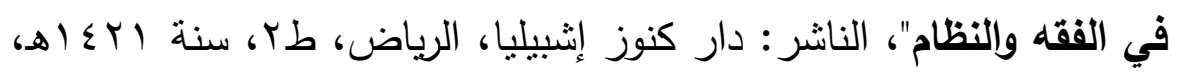
$\cdot r^{r} \cdot 1 \cdot$

خامساً: منهج البحث: سلك الباحث في دراسة (اجتماع المال الحلال بالحرام والتحلل منه وفق القواعد الققهية) منهجين: 


$$
\text { = }
$$

1- المنهج الوصفي: القائم على تحديد طبيعة هذه الظاهرة وبيان خصائصها.

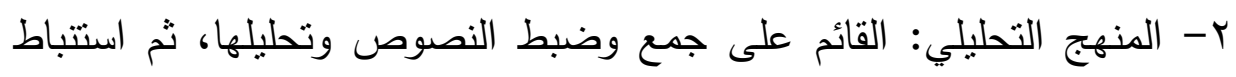

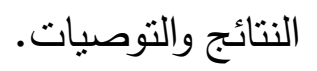
سادساً: خطة البحث: جاء هذا البحث في مقدمة، وتميز ومبحثني، وخاتمة، على

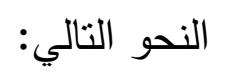

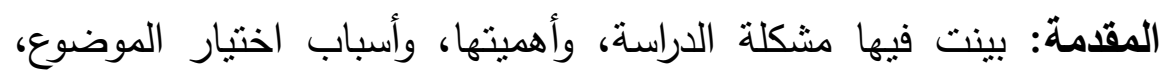
وأهدافه، والدراسات السابقة حول الموضوع، ومنهج البحث وخطة البحث. التمهيد: ذكرت فيه أمر الله بالتحلل من المال الحرام. المبحث الأول: القاعدة الفقهية: مفهومها وتطبيقاتها. المبحث الثاني: أثز القاعدة الفقهية في التحلل من المال الحرام. الخاتمة: ذكرت فيها أهم النتائج والتوصيات. 
د. · خالا سالم العازمي

\section{تمهيد}

\section{التحلل من المال الحرام}

المال الحرام كما عرفه الإمام الغزالي هو: لاما كان مكتسبًا بطريق محرم؛

كالربا والرشوة والقمار والاحتكاره(")؛ لذا أمر الله عز وجل أنبياءه كما أمر عباده

بتحرِي الكسب الحلال عبر وسائل مشروعة، فحَنْ أَبِي هُرَبْرَةَ رضيَ اللهُ عنهُ فَالَ:

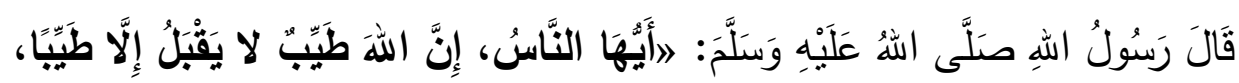

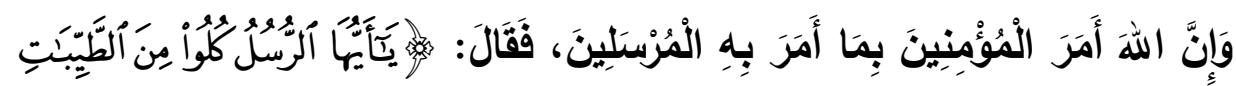

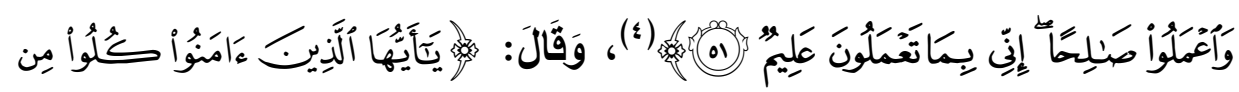

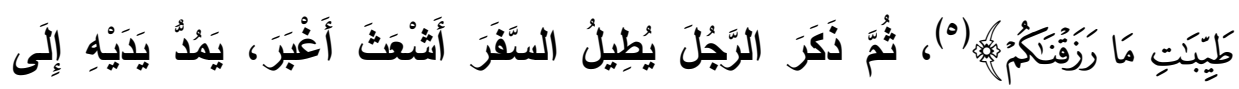

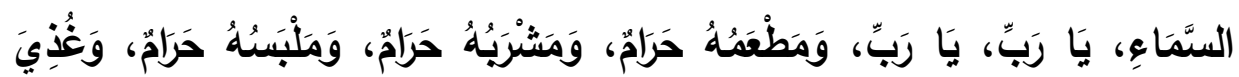

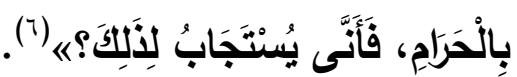

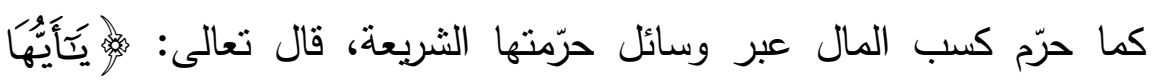

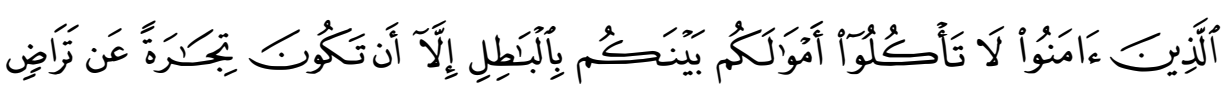
مِّنكمَّ هُ (V)؛ لذا وجب على كل مسلم اكتسب ماله بوسائل محرمة أن يسارع بالتوبة إلى الله أولا، والتحلل من هذا المال الحرام ثانيا، وهذا مصداق قول الله سبحانه

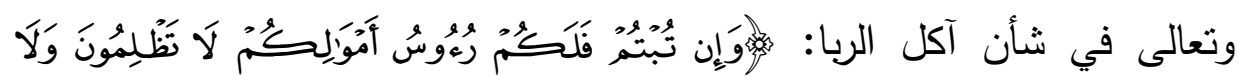

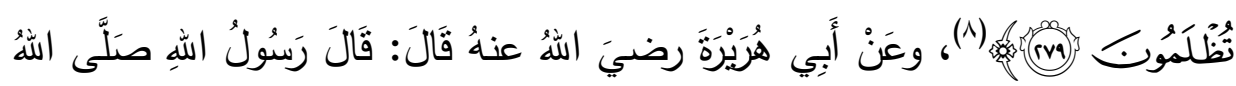

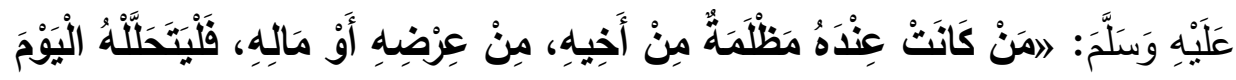

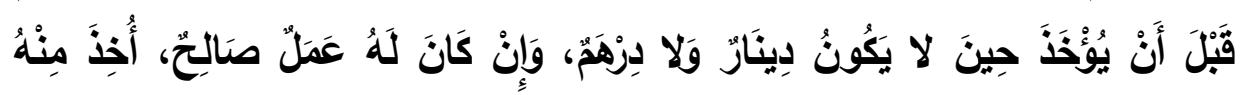

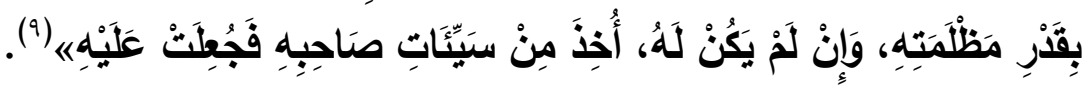
وسنتاول هذا البحث التحلل من المال الحرام في ضوء القاعدة الفقهية: (إذا اجتمع الحلال والحرام غلب الحرام)، معرجين عن مفهوم هذه القاعدة، وأدلتها من هن 
=

الكتاب والسنة دون إسهاب، وتطبيقاتها قديمًا وحديثًا، مع بيان اختلاف الفقهاء في بادي

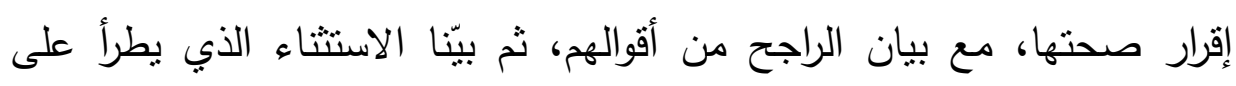
القاعدة، وأسبابه، وتتاولنا أمتلة تتعلق بالأموال، وذلك كله في مبحثني: الأول: القاعدة الفقهية: مفهومها وتطبيقاتها. الثاني: أثر القاعدة الفقهية في التحلل من المال الحرام. 


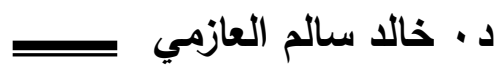

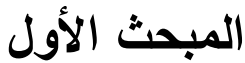

\section{القاعدة الفقهية: مفهومها وتطبيقاتها}

القاعدة: هي الأمر الكلي المنطبق على جميع جزئياته(·').

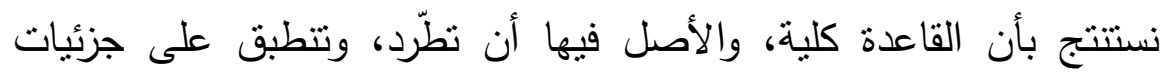

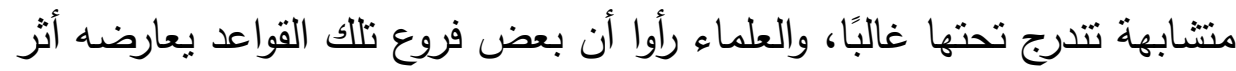

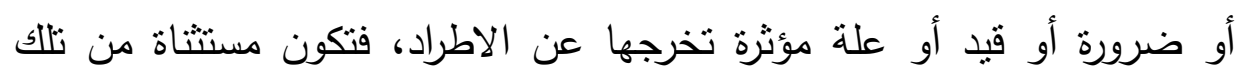

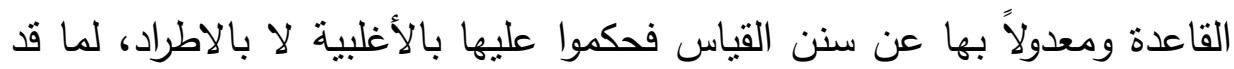
يصييها من استثناء) يقول الثاطبي: (الأمر الكلي إذا ثبت كليَّا، فتخلف بعض الجزئيات عن مقتضى الكلي لا يخرجه عن كونه كليًّا)(ז'ا").

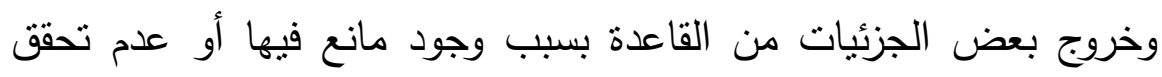
شرط من شروطها، أو هي مندرجة تحت حكم قاعدة أخرى من باب نتازع المسألة

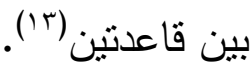

المطلب الأول: نص القاعدة وألفاظها ومعناها وشروط تطبيقها:

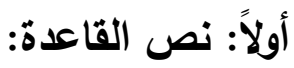
نص هذه القاعدة هو : "إذا اجتمع الحلال والحرام غلب الحرامه|؛ (1). ثانياً: ألفاظ القاعدة: وردت هذه القاعدة بألفاظ متعددة عند العلماء، وهي:

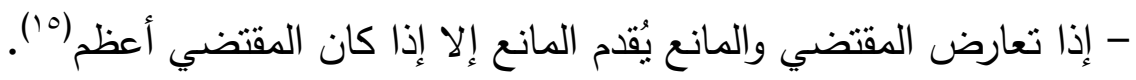

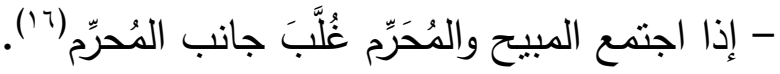

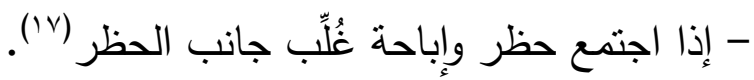

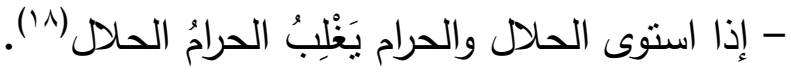

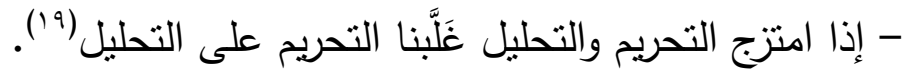




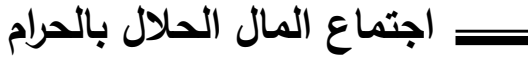

هذه قاعدة فقهية مشتقة من حديث يُنسب إلى رسول الله صلى الله عليه وسلم

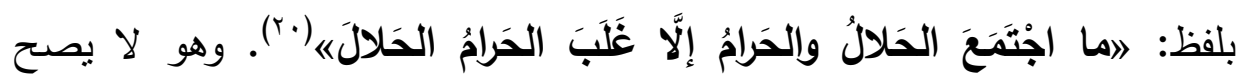

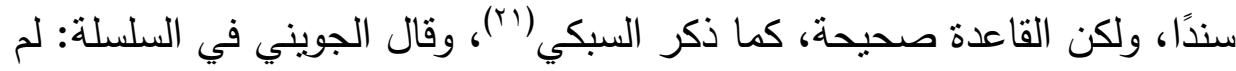

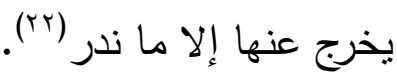
ثالثاً: مفهوم القاعدة ومعناها: مفهوم القاعدة هو : إذا اجتمع في المسألة الحكمية - سواء اجتماعاً حقيقياً أو أو أولاء

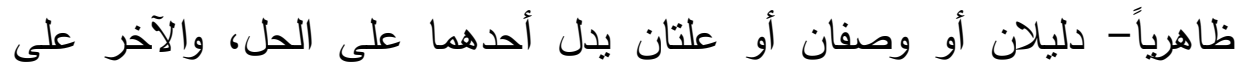

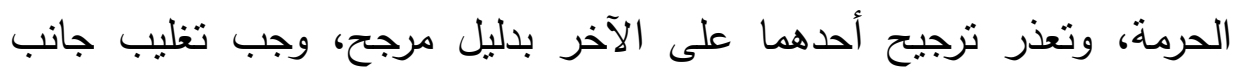
الحرمة على الحل، من باب العمل بالتقوى، والاحتياط بالبعد عن الثبهات التي ولثي

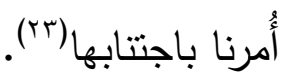

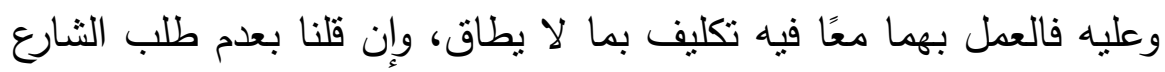

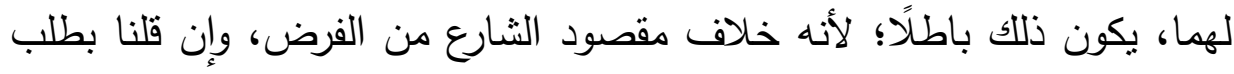

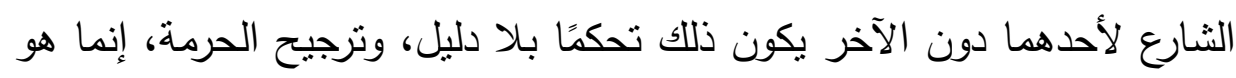

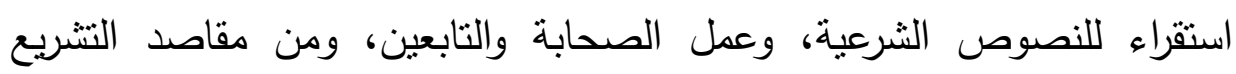

$$
\text { الإسلامي والاجتهادات الفقهية في الفروع (rأ). }
$$

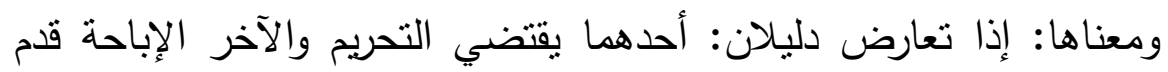

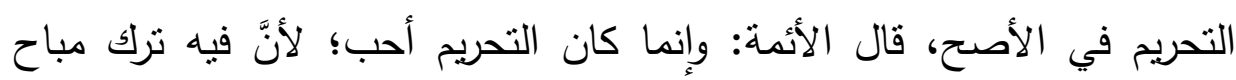
لاجتتاب محرم، وذلك أولى من عكسه (ro). رابعاً: شروط تطبيق القاعدة:

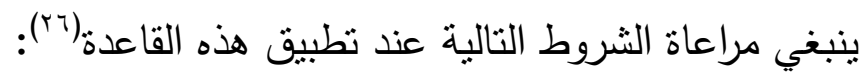

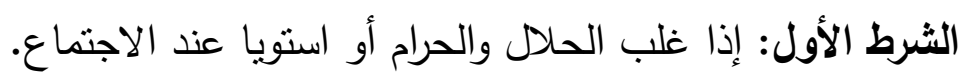

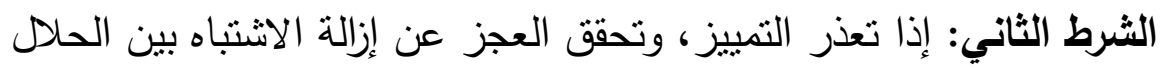
والحرام عند الاجتماع. 


\section{د د خ الاد سالم العازمي}

الثرط الثالث: أن يكون الحال متعلقًا بالمباحات وليس بالواجبات. الشرط الرابع: أن يكون للمكلف ضرورة في هذه الصور . المطلب الثاني: أدلة القاعدة: أولاً: من الكتاب الكريم: يستدل على القاعدة من القرآن الكريم بقول اله

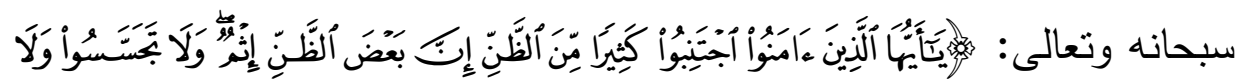

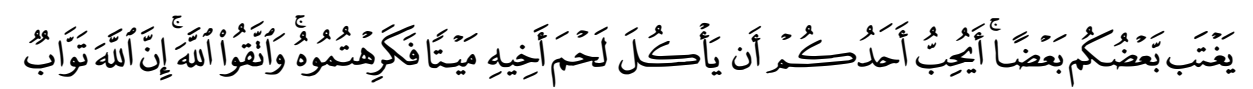

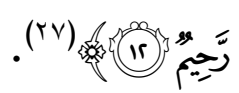

وجه الالالة: قال السبكي: الفلا يخفى أنه أمر باجنتاب بعض ما ليس بإثم

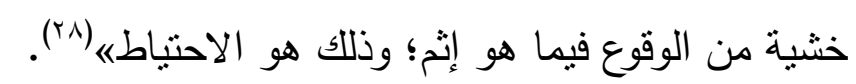

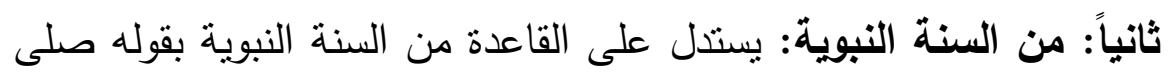

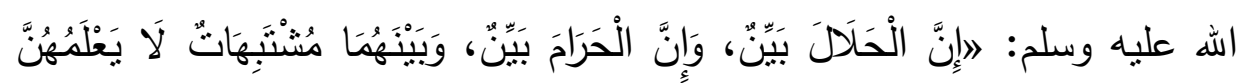

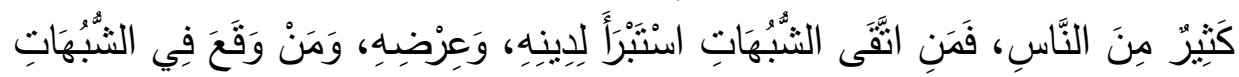

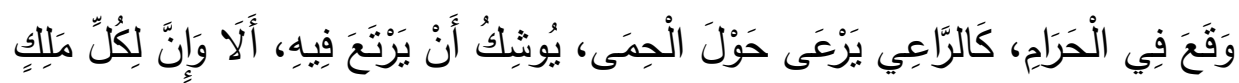

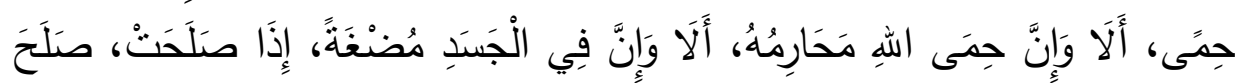

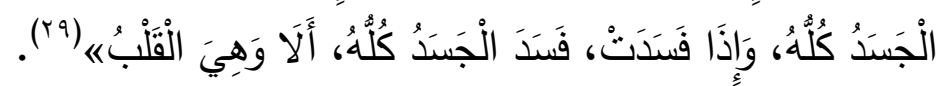
وجه الدلالة: الاستبراء من الحرام يكون بالبعد عن المشتبه، فلا يُدْرى أحلال هو أم حرام، ولذلك يجب اجتتابه؛ فإن كان حرامًا فقد برئ من التبعة، وإن كان حلالا فقد

$$
\text { استحق الأجر على الترك(·r). }
$$

المطلب الثالث: تطبيقات القاعدة في السنة والآثار وأقوال العلماء(باء):

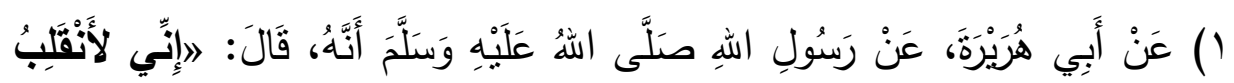

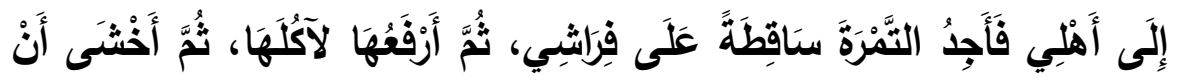

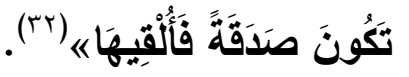


=

ووجه الدلالة: اجتمع الحلال وهي التمرة في بيته صلى اله عليه وسلم

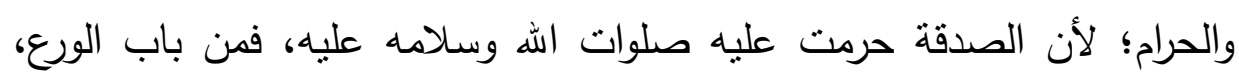

$$
\text { وتنغليب الاحتباط تركها. }
$$

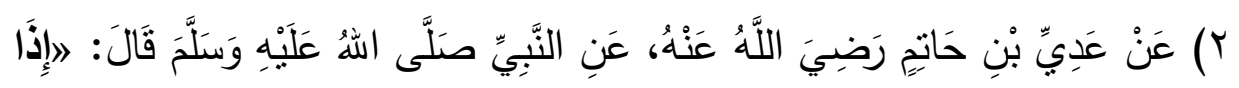

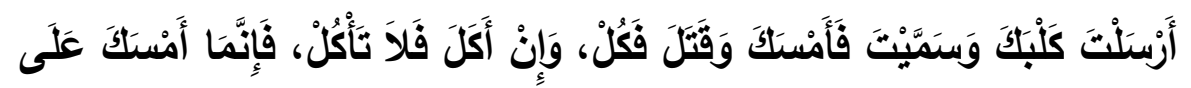

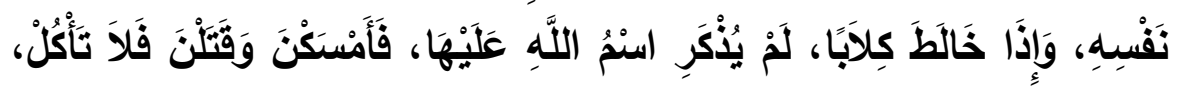

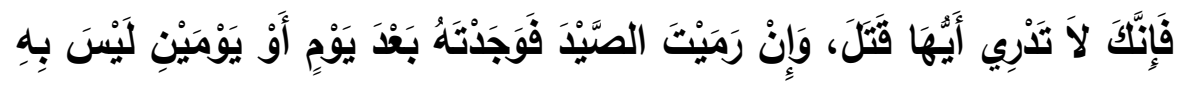

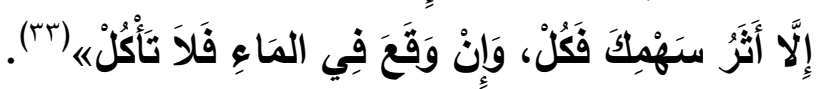
ووجه الدلالة: اجتمع الحال وهو أثز السهم في الفريسة والحرام، وهو

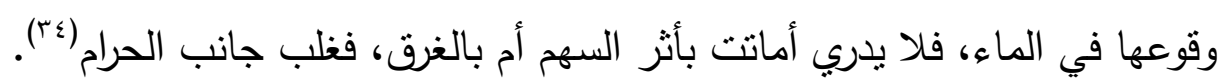

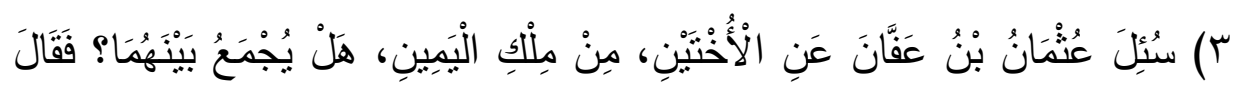

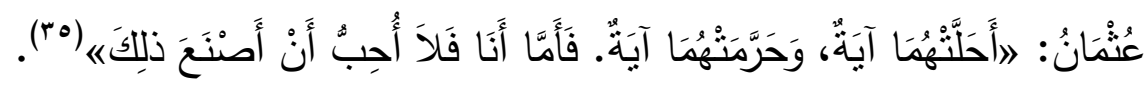
§) ومنها تعارض حديث 》الك من الحائض ما فوق الإزاره، وحديث 》اصنعوا كل شيء إلا النكاحه، فإنَّ الأوّل: يقتضي تحريم ما بين السرة والركبة، والثناني: بقتضي إباحة ما عدا الوطء، فيرجح التحريم احتباطًا.

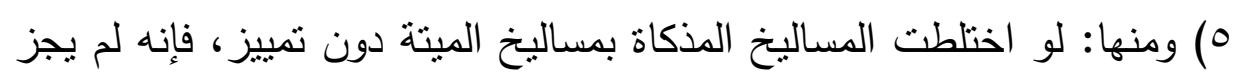

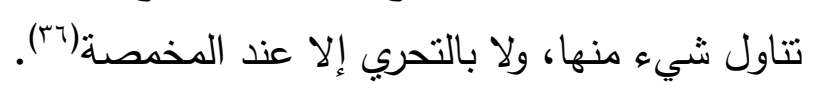

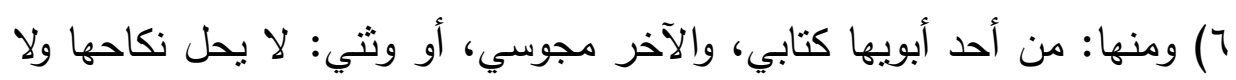

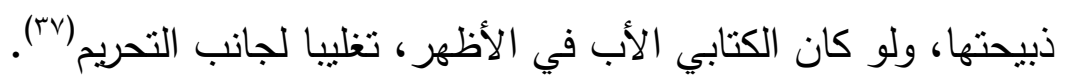

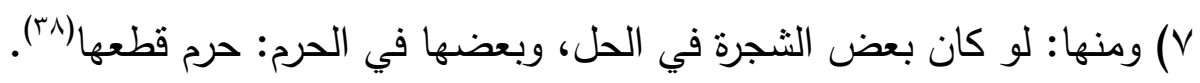

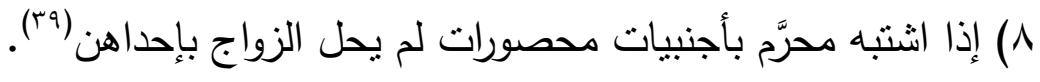




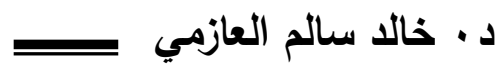

\section{ومن تطبيقاتها المعاصرة:}

() حكم الأسهم المختلطة والشركات المساهمة، التي تتوعت تعاملاتها باختلاط المباح منها بالحرام، بناء على نصوص الثربعة الدالة على وجوب الابتعاد

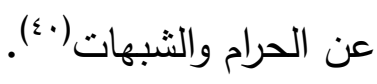

r) الدواء المشتمل على مادة محرمة، وأخرى مباحة، فيغلب جانب التحريج( (ء). r) رفع أجهزة الإنعاش عمن مات دماغه(r؟).

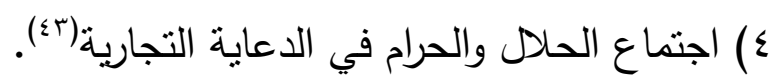

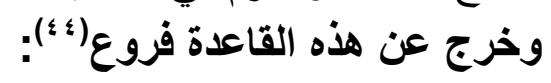

() منها: الاجتهاد في الأواني والثياب، والثوب المنسوج من حربر وغيره يحل إن فرأ كان الحرير أقل وزنا، وكذا إن استويا في الأصـح، بخلاف ما إذا زاد وزنًا. r) ونظيره: التفسير ، يجوز مسه للمُحْدِث إن كان أكثر من القرآن، وكذا إن استويا في الأصح، إلا إن كان القرآن أكثر.

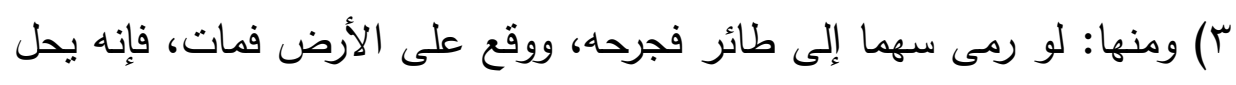
وإن أمكن إحالة الموت على الوقوع على الأرض ؛ لأن ذلك لا بد منه، فعفي عنه. ع) ومنها: لو اعتلفت الثاة علفا حرامًا لم يحرم لبنها ولحمها، ولكن تركه أورع. نقله في شرح المهذب عن الغزالي (ه؛). المطلب الرابع: أقوال العلماء في حكم اجتماع الحرام مع المباح: اختلف الأصوليون والفقهاء في حكم اجتماع الحرام مع المباح على ثلاثنة

القول الأول: إنه يترجح ما دلّ على التحريم، وإليه ذهب جمهور

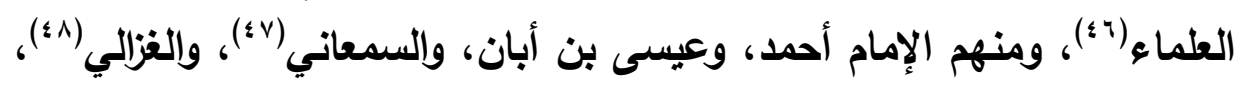

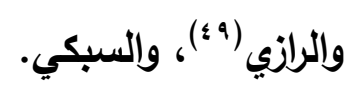


=

أدلتهم:

1- أنّ في ترجيح ما يفيد التحريم أخذًا بالاحتياط، لقوله صلى اله عليه وسلم: (إن الحلا بين والحرام بين وبينهما أمور مشتبهات...الحديث)، وقد دلت فئل

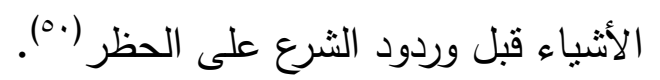

r- إن ترجيح التحريم تأسيس لحكم جديد، وهو بخلاف الأصل، والقاعدة تقول:

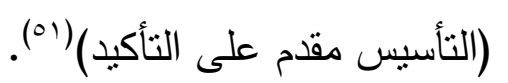

r- ترك هذه الأثياء نرك للاحتباط، وتعريض النفس للغرر، بينما الإباحة لا إثم

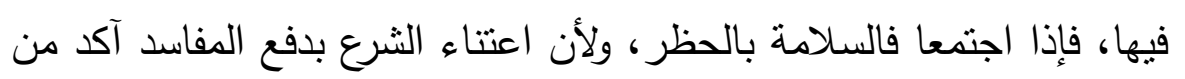

$$
\text { اعتنائه بجلب المصالح (بr). }
$$

القول الثاني: إنه يترجح ما دلّ على الإباحة، وهو قول الآلمدي وإين

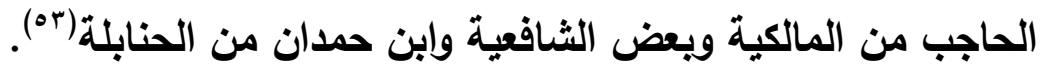
أدلتهز: 1- أنّ ترجيح الإباحة تقوى بترجيح الأصل، وهو أن الأصل في الأثياء الإباحة،

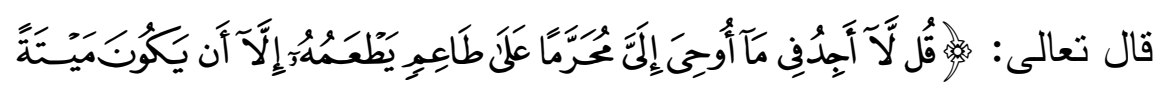

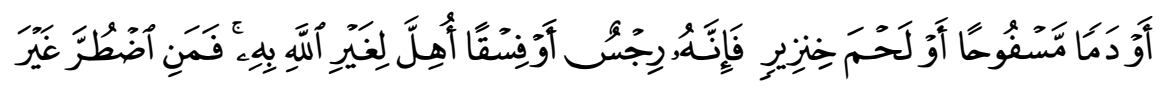

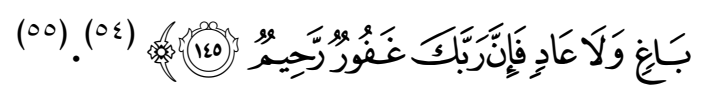

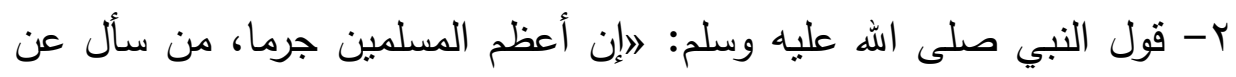

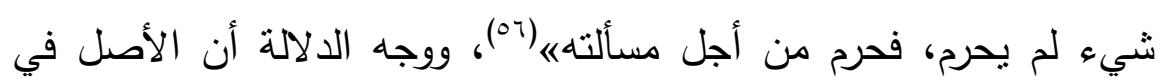

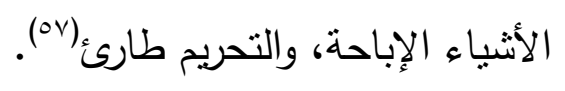

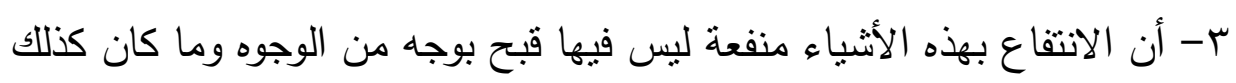

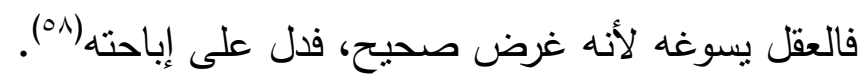

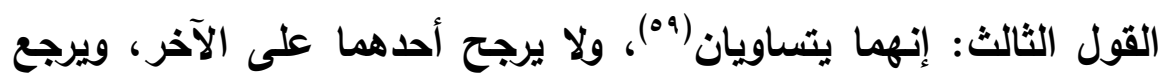
في حمم الحادثة إلى غيرهما، وإليه ذهب الجويني والغزالي والثشيرازي (·"). 
د · · خالا سالم العازمي

أدلتهم: - 20 - 20

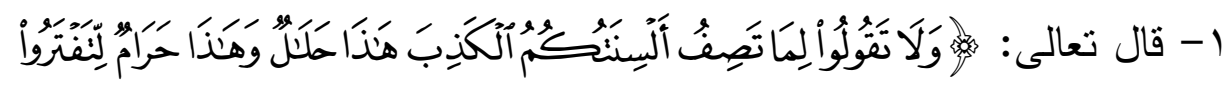

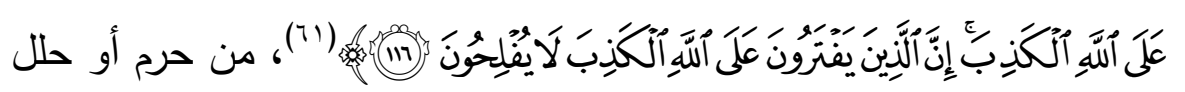
بغير نص فقد شمله حكم هذه الآية، فوجب التوقف (rآ). r- إن الإباحة تقوت بحكم الأصل، والحرمة تقوت بالاحتياط فهما متساويان، وعند التساوي يتساقط الاليلان، والعمل بأحدهما دون الآخر تحكم بلا دليل، وفي إعمالهما معًا جمع بين النقيضين (rآ). الثرجيح:

هذه المسألة لها علاقة وثيقة بمسألة حكم الأشياء قبل ورود الثرع، فمن حكم بأن الأشياء قبل ورود الثرع على الحظر، فعند تعارض الحظر والإباحة رجح

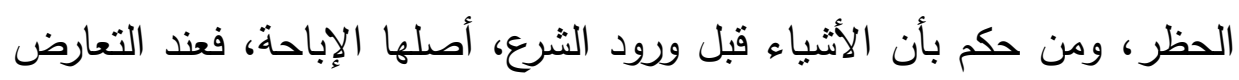
رجح الإباحة، ومن حكم بأن الأشياء قبل ورود الثرع، أصلها التوقف، فعند التعارض، قال بالتساوي، ورجع إلى أدلة ومرجحات أخرى. والراجح والله تعالى أعلم هو القول الأول، قول الجمهور القائل بتغليب الحظر على الإباحة، وذلك لما يلي: - أن تقديم الحظر على الإباحة فيه اتقاء للشبهات التي أرشدت إلبه الأدلة. - من باب سد الذرائع تقديم الحظر أحوط في دفع المفاسد. - كثرة تطبيق العلماء قديمًا وحديثًا لهذه القاعدة في ترجيحاتهم الفقهية.

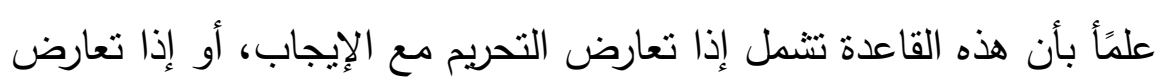
المحرم مع المندوب والمكروه، وكذا إذا تعارض قياسان الأول يقتضي الحظر، والآخر الإباحة، يقدم قياس الحظر ، أما إذا تعارض الوجوب مع المندوب والمكروه والمباح فيرجح الوجوب احتياطًا (ء؟). 
=

والحاصل، بين الحلال والحرام مراتب، لاوضابطها أن الكراهة تشتن بكثرة

الحرام وتخف بكثرة الحلال، فاشتباه أحد الدينارين بآخر سبب تحريم بين، وانشان الشتباه

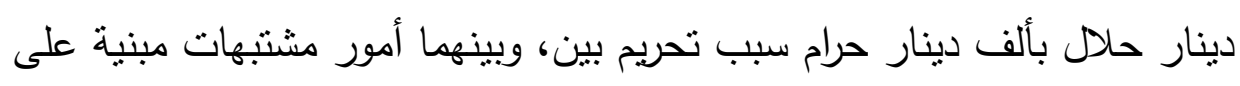

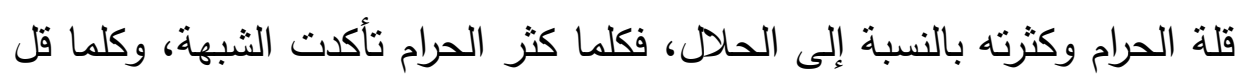
خفت الثبهة إلى أن يساوي الحلد الحرام فتستوي الثبهاته (70). 
د. د خالا سالم العازمي

\section{المبحث الثاني}

\section{أثز القاعدة الفقهية في التحلل من المال الحرام}

في هذا المبحث سنعرج على بعض المسائل المتعلقة بالأموال عامة، والتحلل من المال الحرام خاصة، ولكن ينبخي أن يعلم بأن الفقهاء ذكروا أن المال الحرام بجميع أثكاله إذا كان باقيًا بيد المعتدي، ولم يستهلكه أو بيتل، فيجب ردّه إلى بـ بـاء صاحبه عامَّا كان أم خاصنًا، وسواء عوقب المعتدي على اعتدائه أم لم يُعاقب،

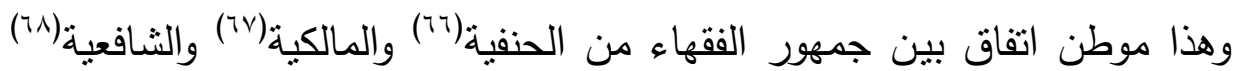

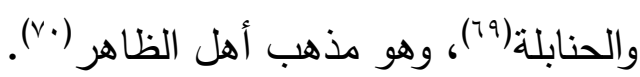

وقد دل على وجوب رد المال المغصوب إلى مالكه الحقيقي الكتاب والسنة

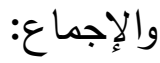

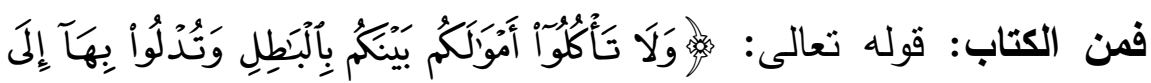

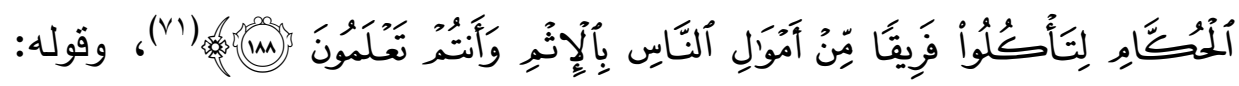

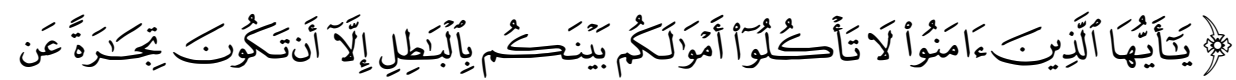

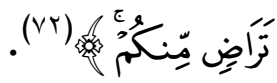

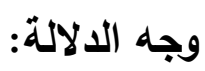

حرم الله في الآيتين السابقتين على عباده المؤمنين أن يأكل بعضهم مال بعض بالباطل، وقد اتفق أهل السنة على أن من أكل مالا حراما قلَّ أو كثر أنه الهن

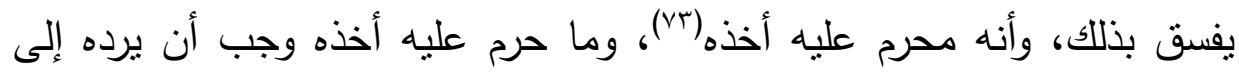

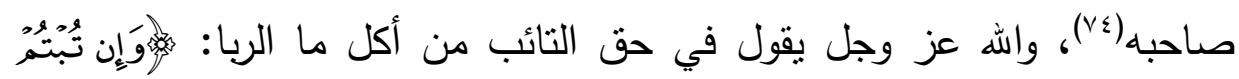

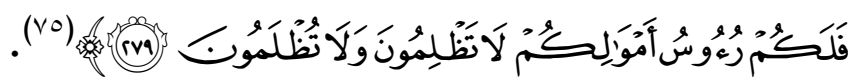

ومن السنة: قول رسول الهه صلى اله عليه وسلم: 》الا يَأْخُذْ أَحَدُكُمْ عَصَا

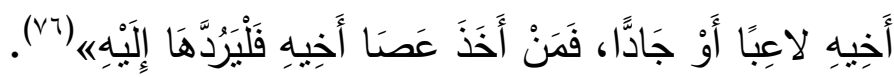


=

أما الإجماع: - أنماع المال

فقال ابن القطان الفاسي: الواتفق الجميع أن على الغاصب رد ما في يده

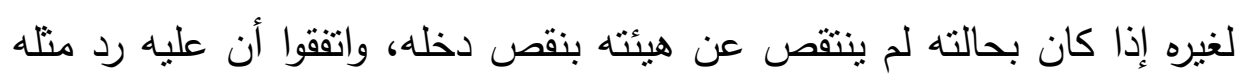

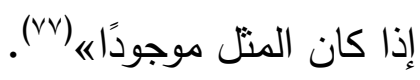

وأما المسائل المالية التي تتاولها العلماء ولها تعلق بالقاعدة الفقهية، فهي تنتاولها المطالب الآتية: المطلب الأول: في الشراء مما في ماله حرام وحلال:

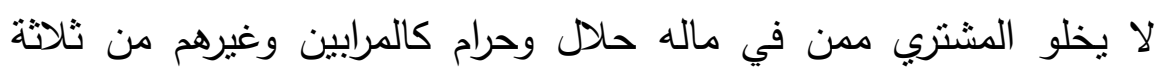
أحوال:

الأول: أن يكون المبيع من حلال أموالهه، فالثراء حلال(V^).

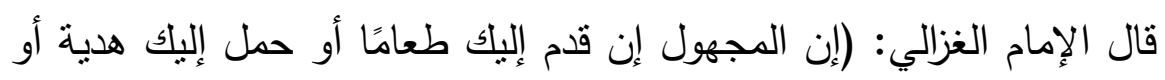

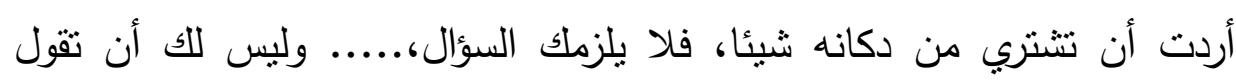

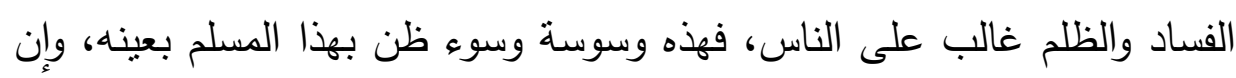

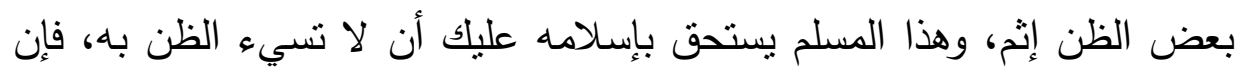

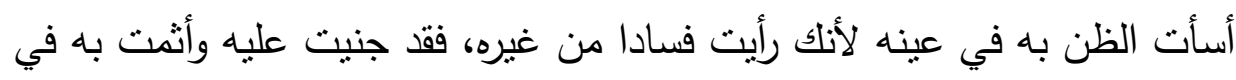

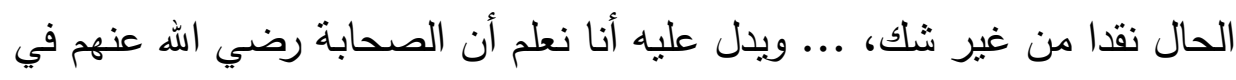

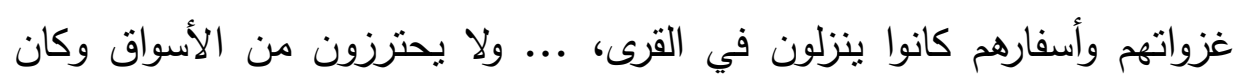

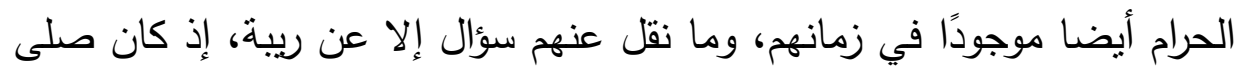
اله عليه وسلم لا يسأل عن كل ما يحمل إليه، بل سأل في أول قدومه إلى الى المدينة

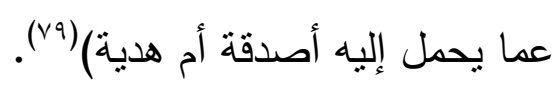

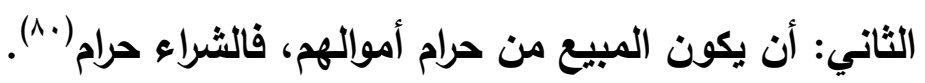

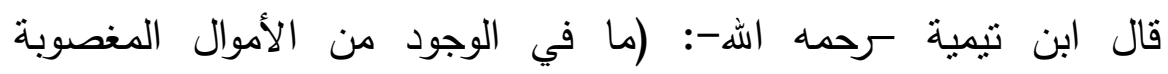

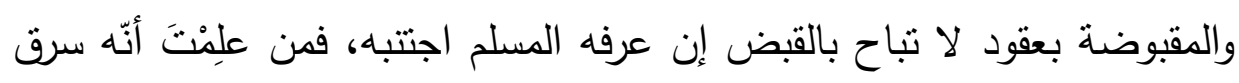


د. د خالا سالم العازمي

مالًا أو خانه في أمانته أو غصبه، فأخذه من المغصوب قهرًا بغير حق لم يجز لي أن آخذه منه؛ لا بطريق الهبة ولا بطريق المعاوضة، ولا وفاء عن أجرة، ولا ثمن مبيع، ولا وفاء عن قرض، فإن هذا عين مال ذلك المظلوم)('^). ويقول الشوكاني: (كان صلى الله عليه وآله وسلم وأصحابه بعاملون اليهود من أهل المدينة وممن حولها، وهم مستحلون لكثيرِ ما حرمه شرعنا، ..... ولم يسمع على كثرة هذه المعاملة وتطأول مدتها أنه صلى الله عليه وسلم، قال: هذا كافر لا تحل معاملته، ولا قال أحد من الصحابة كذلك، وإذا كان هذا في معاملة الكفار الذين هذا حالهم وملكهم، فكيف لا تجوز معاملة من هو من المسلمين مع تلبسه بشيء من الظلم، فإن مجرد كونه مسلما يردعه عن بعض ما حرمه الله عليه، وإن وقع في بعض المحرمات تتزه عن بعضها، فغاية الأمر ما في يده قد يكون مما هو حرام، وقد يكون مما هو حلال، ولا يحرم على الإنسان إلا ما هو نفس الحرام وعينه)(זن). الثالث: أن يكون المبيع غير معلوم الحال.

فهرنا يكره المبيع لاحتمال أن يكون المبيع من الحرام، لكن الييع غير باطل، لاحتمال أن يكون المبيع من الحال، وكلما قل الحرام قلت الثبهة، والعكس صحيح(r^)، قال أبو القاسم الصفار : الأشياء على ظاهر ما جرت به العادة؛ فإن كان الغالب الحلد في الأسواق لا يجب السؤال، وإن كان الغالب الحرام في وقت أو كان الرجل يأخذ المال من حيث وجده، ولا يتأمل في الحلال والحرام فالسؤال عنه حسن (ع^). وهذه المعاملة تتطبق عليها القاعدة إذ اختلط الحرام بالحلال، فغلب الحرام. ومن تطبيقاتها المعاصرة، شعور الأولاد والزوجات بالحرج من كسب آبائهم وأزواجهم حيث إنهم خلطوا هذا الكسب بالحرام، فإن كان هذا الحرام يسيرًا فالحكم للغالب، ومدار الأمر على الثبهة، وأما إن كان الحرام غالبًا، فقي هذه الحالة لا بأس لمن هم تحت ولايته أن يأخذوا قدر حاجتهم دون توسع أو إسراف(^هـ. 


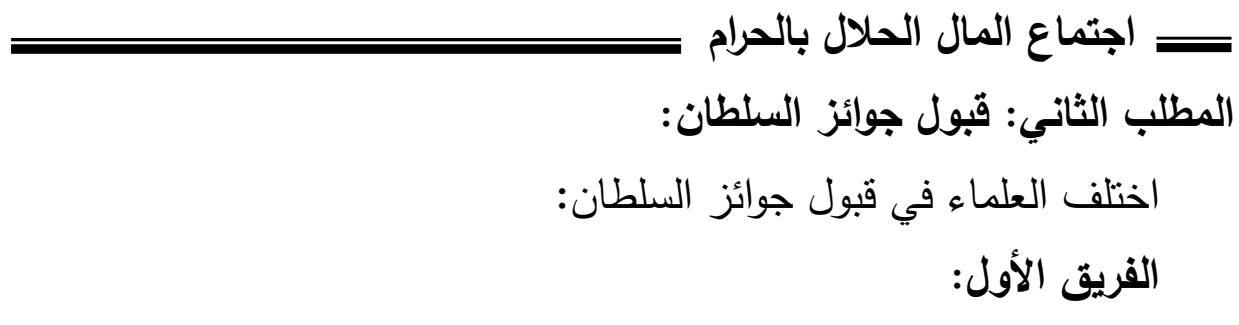

كرهها على سبيل الورع والاحتياط، منهم سعيد بن المسيب والثثري وابن

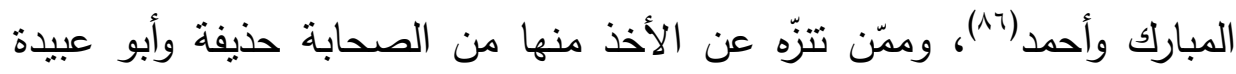
ومعاذ وأبو هريرة وابن عمر وغيرهم.

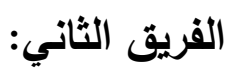

قبول جوائز السلطان وهو قول ابن عمرو وابن عباس وعائشة وغيرهم من

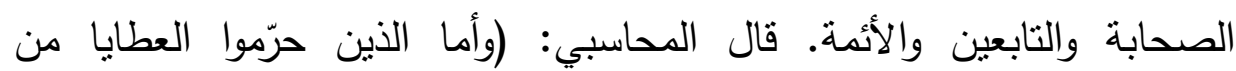
السلاطين فقد غلطوا، لعلة أنه ليس بحرام كله، فكيف يجوز أن يقال حرام وفيه

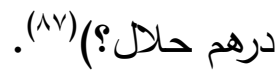

وخلاصة القول، هدايا الإمام لغيره إن كانت من ماله الخاص فلا يختلف

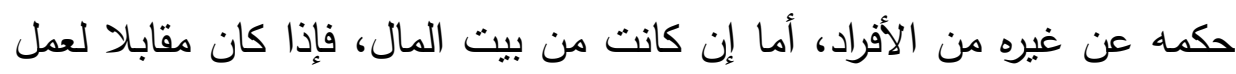

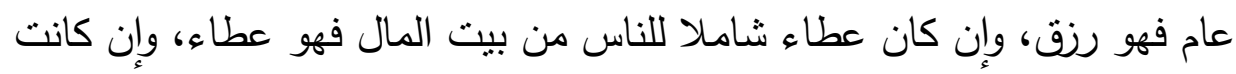

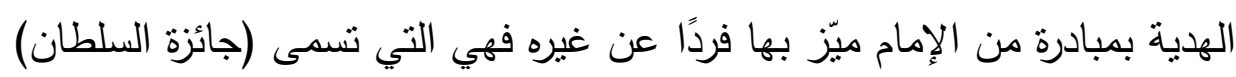
وقد اختلف فيها أهل العلم على أساس أن بيت مال المسلمين قد اختلط فئ فيها فئا أموال

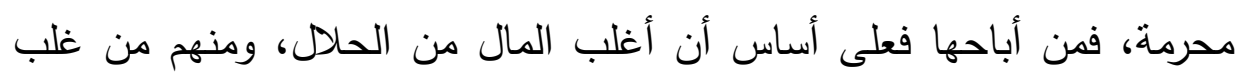

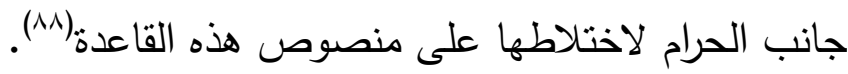

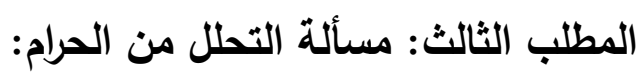
وعليه، هل يستثنى من اختلط ماله بالحرام قلّ منه أو كثر من هذه القاعدة؟ القُ

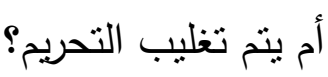
يرى شيخ الإسلام ابن تيمية أن المحرم على نوعين؛ محرم لعينه كالمينة، ومحرم لغيره كالنهب والسرقة، فأما الأول وهو المحرم لعينه، إذا اختلط بما لا لال 


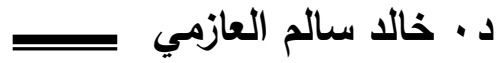

ينحصر كالميتة، فلا يحرم، وإذا اختلط بما ينحصر كالأخت من الرضاعة بأجنبية حرّت، وأما الآخر كالمحرم لغيرهن كالربا، إذا اختلط لم يحرم جميعه، بل يستخرج منه الحرام، والباقي يطيب لصاحبه، والمسألة الأخيرة هي الثاهد من هذا البحث، أن اختلاط المال لا يحرمه كله، وهو قول جماهير العلماء. يقول ابن تيمية رحمه الله: (المحرمات نوعان: محرم لوصفه وعينه كالدم والميتة ولحم الخنزير، فهذا إذا اختلط بالمائع وظهر فيه طعم الخبث أو لونه أو وعنه ريحه حرم. ومحرم لكسبه كالنقدين والحبوب والثمار وأمثال ذلك، فهذه لا تحرم أعيانها تحريما مطلقا بحال ولكن تحرم على من أخذها ظلما أو بوجه محرم، فإذا أخذ الرجل منها شيئا وخلطه بماله فالواجب أن يخرج من ذلك القدر المحرم وقدر

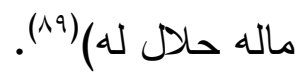
أقوال جمهور العلماء تقضي بذلك، منهم: - ففي فتاوى ابن الصلاح: لو اختلط درهم حلال بدراهم حرام، ولم يتميز فطريقه: أن يعزل قدر الحرام بنية القسمة، ويتصرف في الباقي، والذي عزله إن إن علم صاحبه سلمه إليه، وإلا تصدق به عنه، وذكر مثله النووي وقال: اتقق أصحابنا، ونصوص الثافعي على منله فيما إذا غصب زيتا أو حنطة، وخلط بمثله، قالوا: يدفع إلبه من المختلط قدر حقه، ويحل الباقي للغاصب، قال: فأما ما

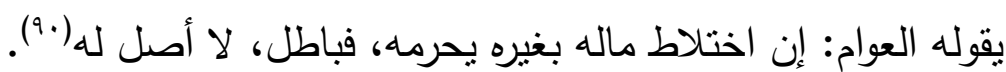
- وقال الإمام أحمد في المال المشتبه حلاله بحرامه: إن كان المال كثيرا أخرج منه قدر الحرام((9)، وتصرف في الباقي، وإن كان المال قليلا، اجتتبه كله، وهذا لأن القليل إذا تتاول منه شيئا، فإنه تبعد معه السلامة من الحرام بخلاف

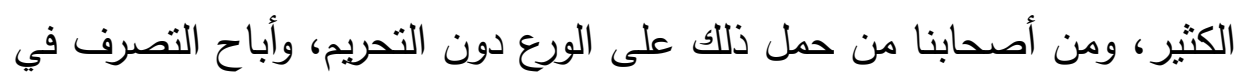
القليل والكثير بعد إخراج قدر الحرام منه، وهو قول الحنفية وغيرهم، وأخذ به قوم من أهل الورع منهم بشر الحافي( بهون. 
- وقد ذكر ابن القيم رحمه اله قاعدة عظيمة في اختلاط المباح بالمحظور

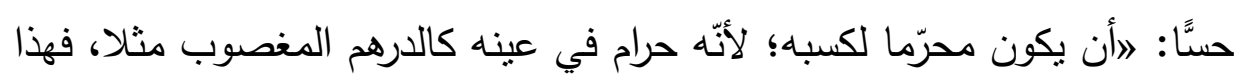

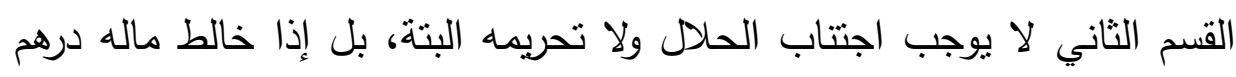
حرام أو أكثر منه أخرج مقدار الحرام وحل له الباقي بلا كراهة سواء كان المخرج

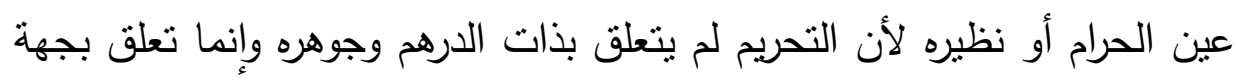

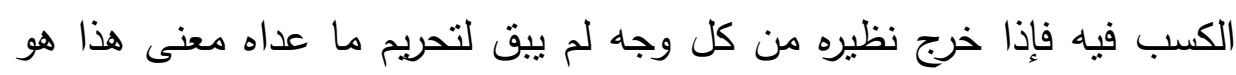

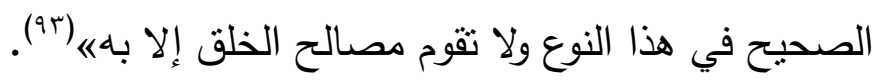

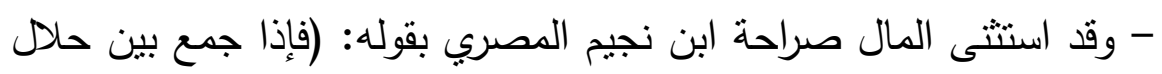

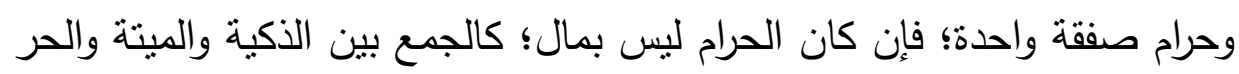

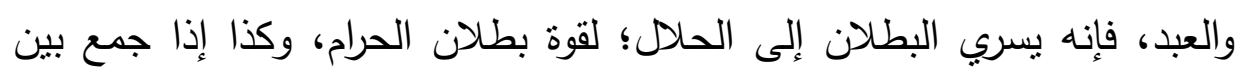
خل وخمر . وإن كان الحرام ضعيفا كأن يكون مالاً في الجملة، كما إذا جمع بين المدبر

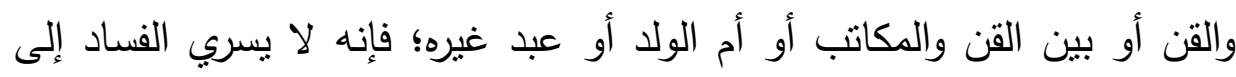

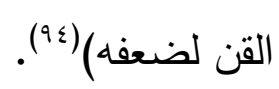

ورأى بعض أهل الورع حرمة المال كله، يقول ابن العربي: (ذهب بعض الغلاة

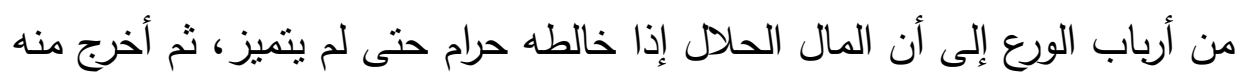

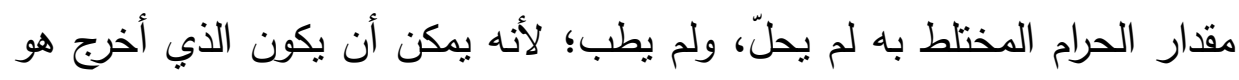

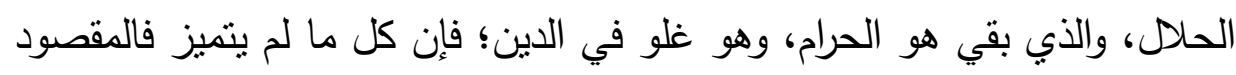

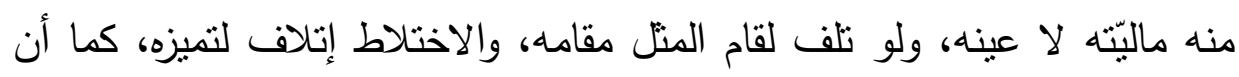

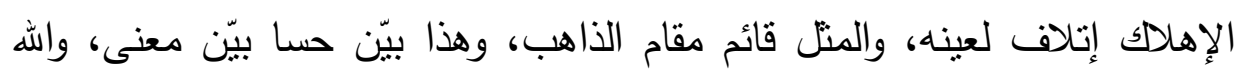
أعلم)(90).

ويؤكد الإمام الغزالي هذا المعنى بقوله: (أن يقترن بنالك العين علامة تدل

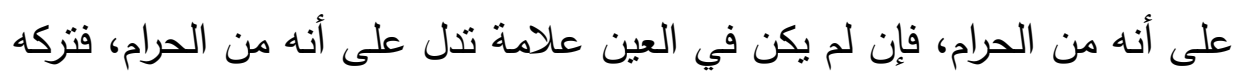

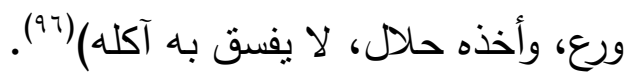




\section{د. د خالا سالم العازمي}

وعليه، فإنّ اختلاط المال الحرام بالمال الحلال لا يحرمه كله، ولا تتطبق عليه القاعدة الفقهية، فهو مستثىى منها، وذلك للأسباب التالية: 1- عدم تطبيق كثير من العلماء لهذه القاعدة على المتحلل من المال الحرام، يدل على استثنائها. ץ- القاعدة تخالف نصَّا شرعيًّا يعد حجة في مسألة التطهر من المال الحرام،

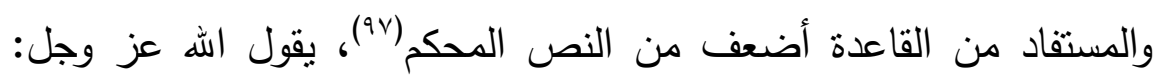

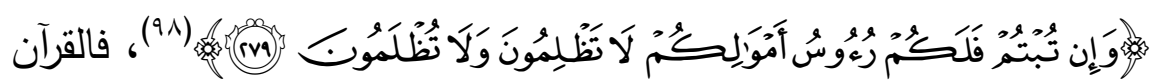
أرشد المتحلّل من ماله الحرام بإمساك ماله الحلال، ولم يأمره بالتخلص منه، يقول ابن رشد القرطبي الجد في شأن من كان في ماله شيء من الحرام: الالواجب عليه في خاصة نفسه: أن يستغفر الله تعالى، ويتوب إلبه، برد ما عليه من الحرام لأربابه إن عرفهم، أو التصدق به عنهم إن لم يعرفهم ... وما كان من ذلك من ربا، أربي فيه في عرض، أو دين، لزمه أن يتصدق أن لأن إنه بالزائد على رأس ماله من الدين أو العرضيه(99). ץ- أنّ هذه المسألة نتتازعها قاعدتان فقهينان، الأولى: إذا اجتمع الحلال والحرام غلب الحرام، والقاعدة الثانية: يقول السيوطي: ولهم قاعدة عكس هذه القاعدة، وهي »الحرام لا يحرم الحلاله(·.")، والقاعدة الثانية أقرب لمن أراد أن يتطهر من المال الحرام، فكيف يحكم عليه بحرمة ماله الحلال؟ ع- للقاعدة تطبيقات، تجعلها مرنة، فيها طواعية للنصوص الصريحة؛ فمنهم من يرى؛ إذا تردّد الأمر بين الحرام أو المكروه والحله غَلَب الحرامُ الحلال فكان فئه ترك الفعل أولى، لكن إذا تردّد الأمر بين الحرام والفرض أو الواجب فردّ إنّ الفعل هنا أولى من التّلك إلا إذا كانت مفسدة الحرام أعظم. ومن أمتلة هذه القواعد: سفر المرأة المسلمة من بلاد الكفّار واجب - ولو وحدها - إذا خثيث الفتنة في دينها، مع أنّ سفرها وحدها بدون محرم حرام وبدعة(1 +()، وهذا ما يمكن 
تطبيقه على مسألة التحلل من المال الحرام، فتحريم مال المتحلل كله، فيه

$$
\text { بخس لحقه، وظلم ظاهر لا يخفى. }
$$

0- من قال بالتحريم من العلماء، قاله من باب الورع والتقوى، والأخذ بالاحتياط.

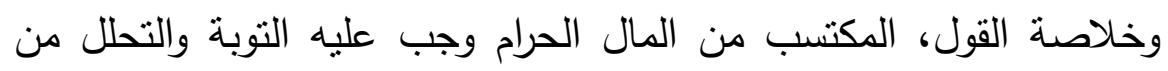

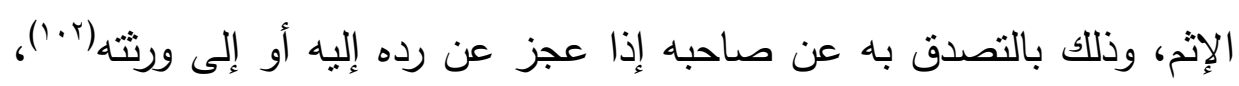
ولا تطبق القاعدة الأصولية عليه وهي: (إذا اجتمع الحلال والحرام غلب الحرام)،

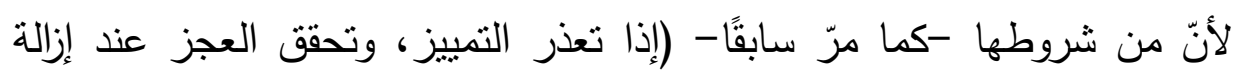

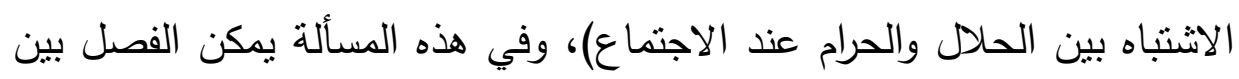

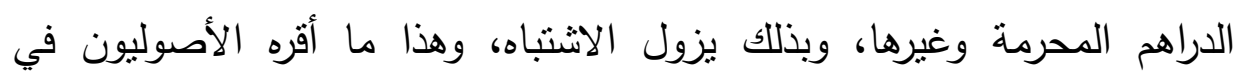

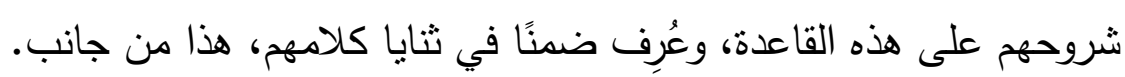

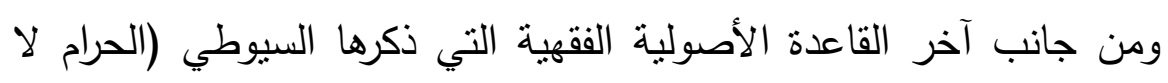

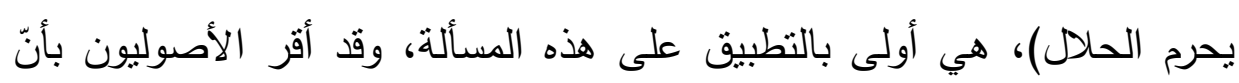

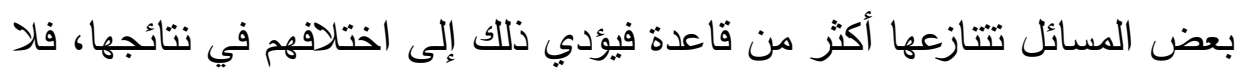

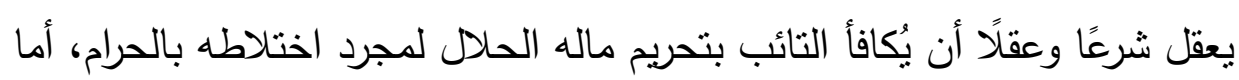

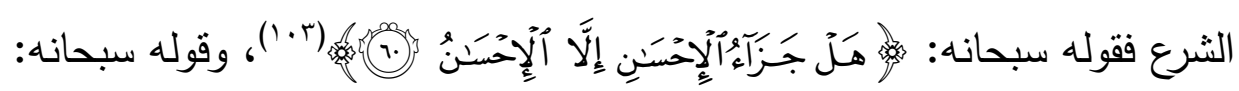

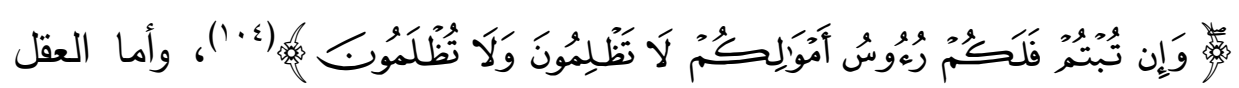
يقضي بأخذ كل ذي حق حقه، وهو ما ذكره وأقره كثثر من العلماء، ومن خالف

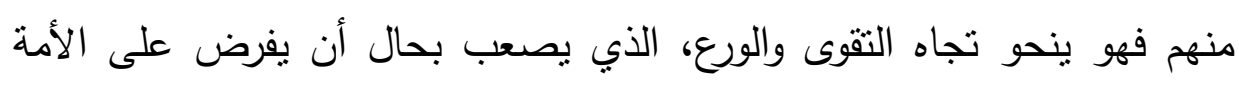

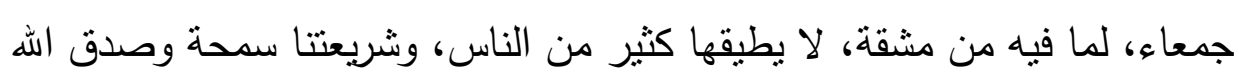

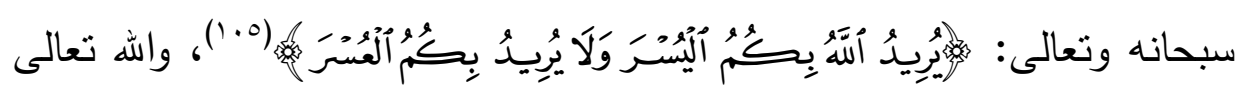

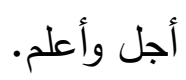


د · خالد سالم العازمي

\section{الخاتمــة}

بعد الانتهاء من البحث خرجت بمجموعة من النتائج وأخرى من التوصيات،

$$
\text { على النحو الآتي: }
$$

1- المال الحرام هو (ما كان مكتسبًا بطريق محرم؛ كالربا والرشوة والقمار

$$
\text { والاحتكار ). }
$$

r- مفهوم قاعدة (إذا اجتمع الحلا والحرام غلب الحرام) هو: إذا تعارض دليلان: أحدهما يقتضي التحريم والآخر الإباحة قدم التحريم في الأصح.

r- يوجد معاملات تجارية يختلط فيها الحلال بالحرام ويغلب عليها الحرام، مثل: مبيع اختلط فيه الحلال والحرام، فيحكم بتحريم هذه المعاملة تتزيلا على هذه

$$
\text { القاعدة. }
$$

ع - اختلاط المال الحرام بالمال الحلال ويمكن فصل أحدهما عن الآخر لا يحرمه كله، ولا تتطبق عليه القاعدة الفقهية، فهو مستثتى منها. ثانيًا: التوصيات:

1- دعوة الباحثين وطلبة الدراسات العليا إلى البحث في القواعد الفقهية وتتزيل القضايا المعاصرة عليها، مما يُظهر أثز هذه القواعد في استتباط الأحكام

$$
\text { الثرعية. }
$$

ץ- دعوة المجامع الفقهية والمؤسسات العلمية لجمع القضايا المستجدة مما له علاقة بالأموال المحرمة، وبيان كيفية التحلل منها وفق القواعد الفقهية. 


\section{=}

\section{قائمة المراجع والمصادر}

1- أحمد بن حنبل الثيباني (ت اع آه). المسند، تحقيق: شعيب الأرناؤوط،

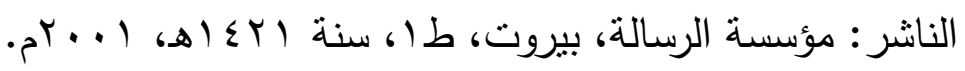

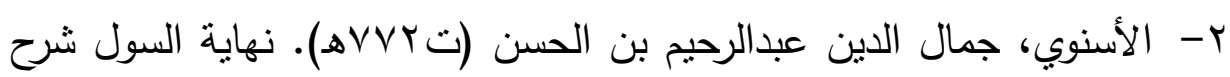

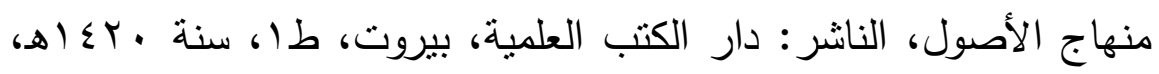
. 1999

r- آل بورنو الغزي، محمد. موسوعة القواعد الفقهية، الناشر : مؤسسة الرسالة،

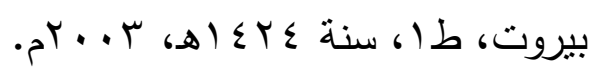

ع- الآمدي، أبو الحسن علي (ت ابآهـ). الإحكام في أصول الأحكام، تحقيق:

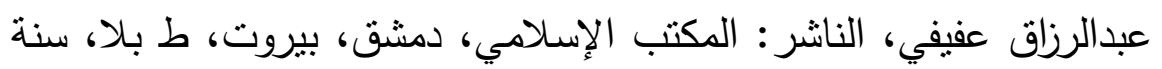

$$
\text { بلا. }
$$

0- ابن أمير الحاج، أبو عبداله شمس الدين محمد، ويعرف بابن الموقت

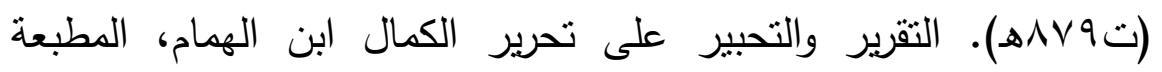

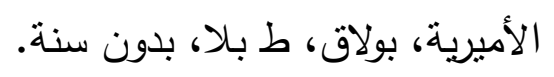

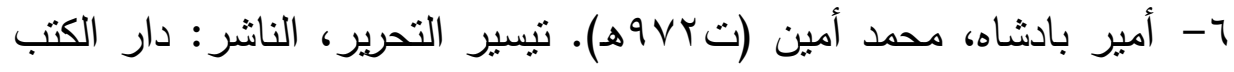

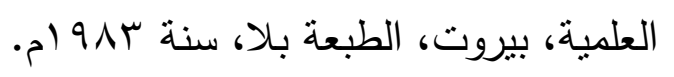

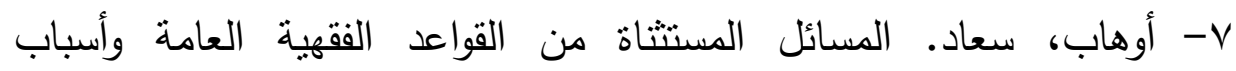

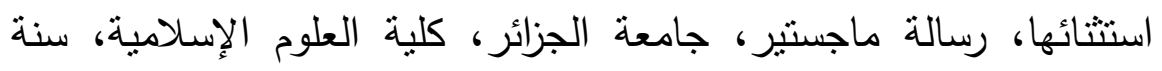

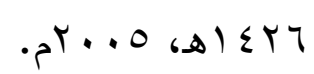

1- الباز، عباس أحمد. المال المحرم وضوابط الانتفاع والتصرف به في الفقه

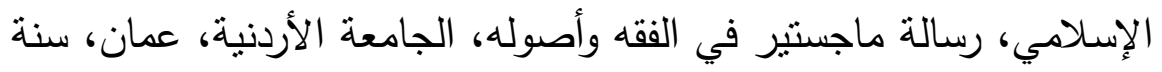

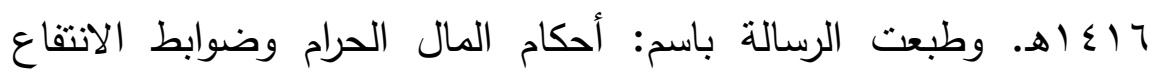

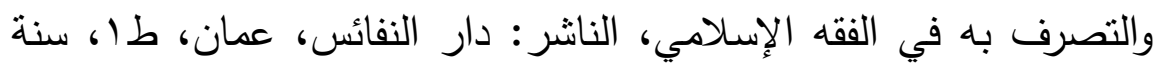

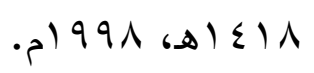




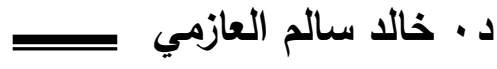

9- البخاري، علاء الدين عبدالعزيز (ت. • هـ). كثف الأسرار عن أصول فخر الإسلام البزدوي، تحقيق: عبداله محمود محمد عمر، الناشر: دار

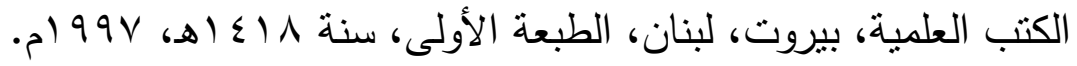
• 1- البخاري، محمد بن إسماعيل (ت بـهـ). المسند الصحيح المختصر من أمور رسول الله صلى الله عليه وسلم وسننه وأيامه، وهو صحيحه، ويُعرف باسم: الجامع الصحيح، تحقيق: محمد زهير الناصر، الناشر: دار طوق

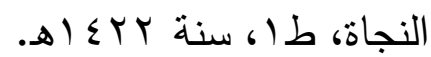
1ا - البغوي، أبو محمد الحسين بن مسعود (ت آ 0 هـ). معالم التنزيل في تفسير القرآن، تحقيق: خالد عبدالرحمن العك، دار المعرفة، بيروت، لبنان، الطبعة الأولى، سنة الطبع بلا.

r ا - البلدحي، عبداله (تrمجه). الاختيار لتعليل المختار، تحقيق: محمود أبو دقيقة، الناشر: مطبعة الحلبي، القاهرة، دار الكتب العلمية، بيروت،

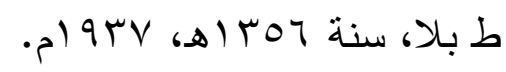
ب ا - البهوتي، منصور بن يونس (ت إه ـ (هـ)، كثاف القناع عن منن الإقناع،

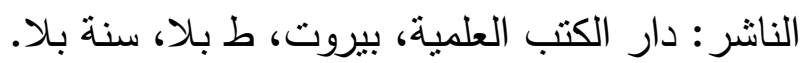
ع ا- البيهقي، أبو بكر أحمد بن الحسين (ت^هـهـ). السنن الكبرى، تحقيق: محمد عبدالقادر عطا، الناشر: دار الكتب العلمية، بيروت، طس، سنة

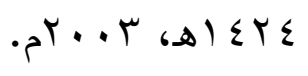

1 - الترمذي، محمد بن عيسى (ت rV9ه). السنن، تحقيق: أحمد محمد شاكر ومحمد فؤاد عبدالباقي وإبراهيم عطوة عوض. الناشر: شركة ومكتبة

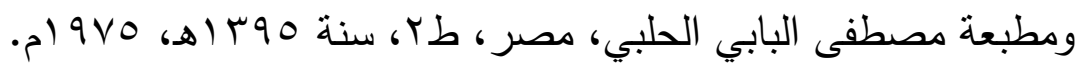

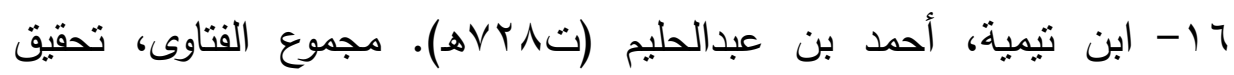

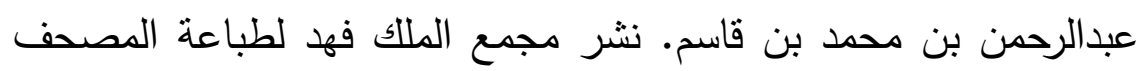

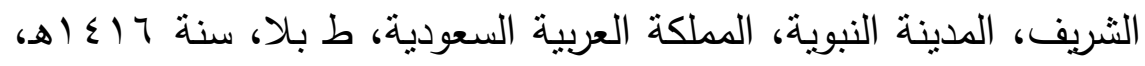


=

IV

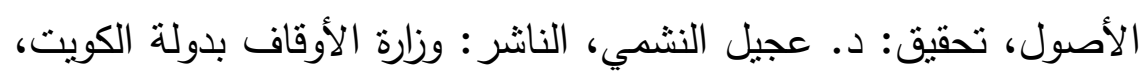

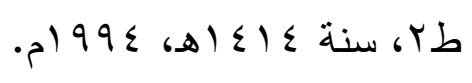

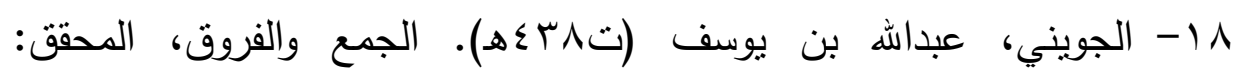

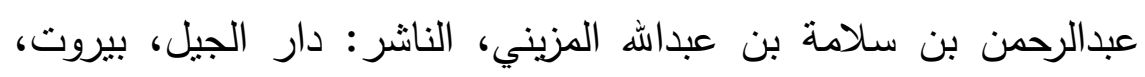

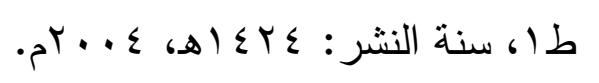

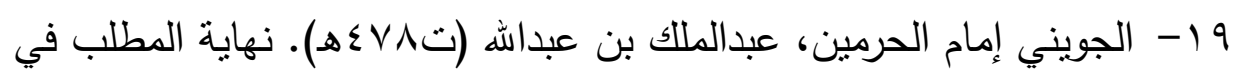

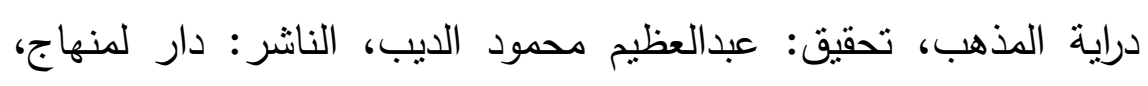

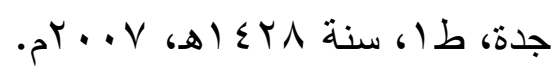
• .

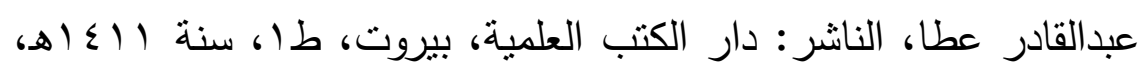
.0199 . اب- ابن حجر الهيتمي، أحمد بن محمد (ت \& وهـ). تحفة المحتاج في شرح

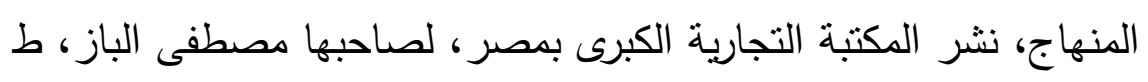

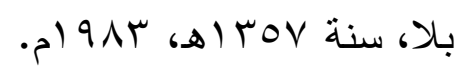

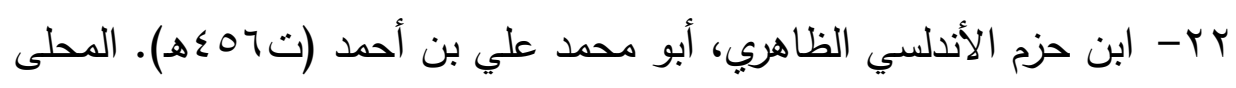

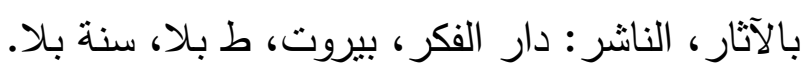

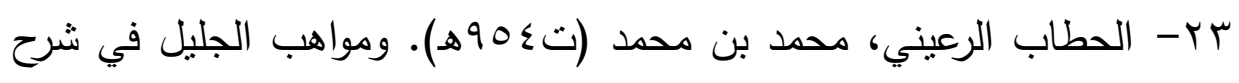

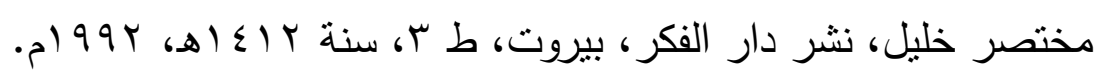

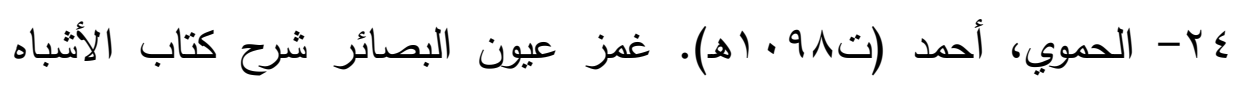

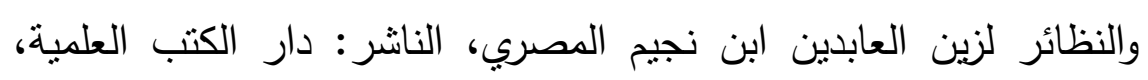

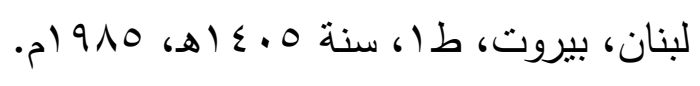




\section{د. • • خالا سـالم العازمي}

هץ- حيدر، علي. شرح مجلة الأحكام العدلية، تعريب: فهمي الحسيني، نشر:

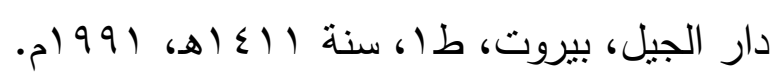

דr- الدارقطني، علي بن عمر (تهمبه). السنن، تحقيق: شعيب الأرنؤوط

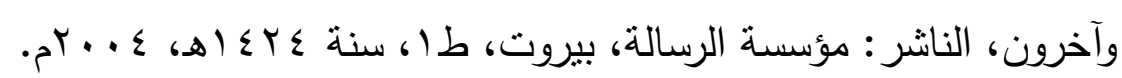

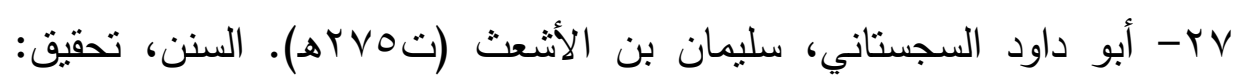
محمد محي الدين عبدالحميد، الناشر: المكتبة لعصرية، صبدا، بيروت، بدون طبعة، بدون تاريخ.

^ץ- الرازي، أبو عبداله محمد بن عمر (7 • דه). المحصول، تحقيق: طه جابر

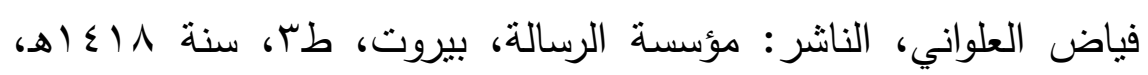

$$
\text { . }(\leqslant \tau \Lambda / r) \cdot(5) 99 \vee
$$

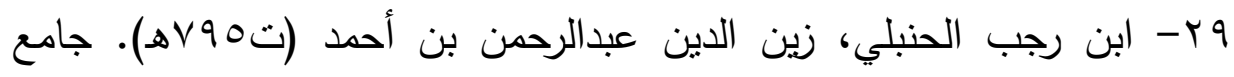
العلوم والحكم في شرح خمسين حديثا من جوامع الكلم، المحقق: شعيب الأرناؤوط وإبراهيم باجس، الناشر: مؤسسة الرسالة، بيروت، الطبعة:

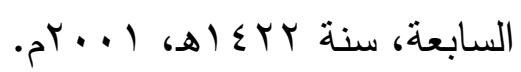

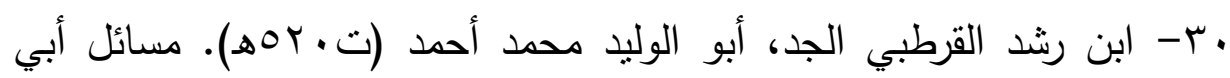
الوليد ابن رشد، تحقيق: محمد الحبيب التجكاني، الناشر: دار الجيل،

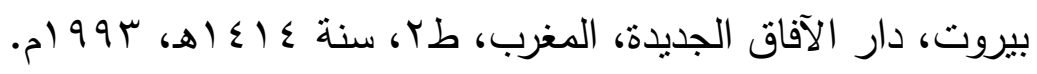
اب- ابن رشد القرطبي الجد، محمد بن أحمد (ت . . بهـ). المقدمات الممهدات، تحقيق: محمد حجي، الناشر: دار الغرب الإسلامي، بيروت، طا، سنة

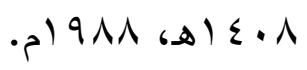

rس- ابن رشد القرطبي الحفيد، محمد بن أحمد (ت900هـ). بداية المجتهد ونهاية المقتصد، الناشر: دار الحديث، القاهرة، ط بلا، سنة هبء اهـ،

$$
\cdot r^{2} \cdot \ldots
$$




\section{اجتماع المال الحلال بالحرام}

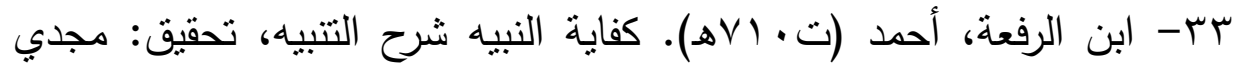

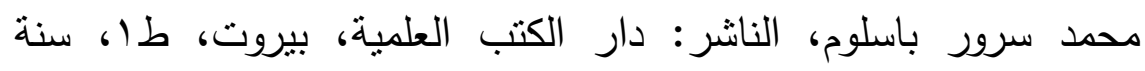

$$
\text { . }
$$

ع ب- الرملي الثهير بالثافعي الصغير، محمد بن أحمد (ع ...1ه). نهاية

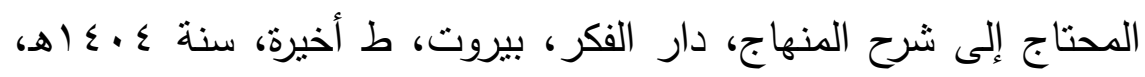

$$
\text { . }
$$

هr- الزحيلي، محمد. القواعد الفقهية وتطبيقاتها في الدذاهب الأربعة، الناشر:

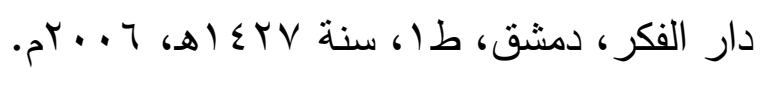

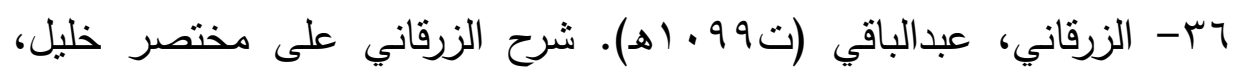

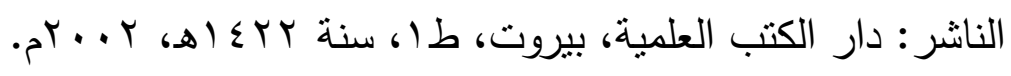

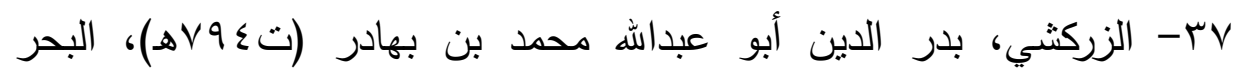

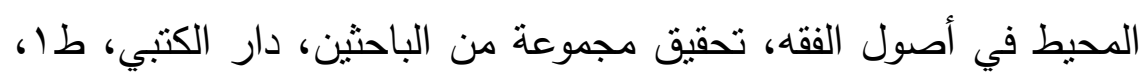

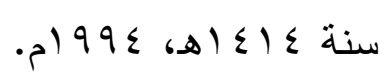

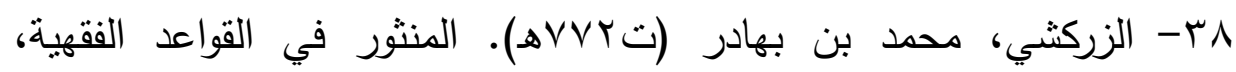

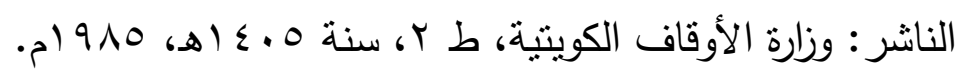

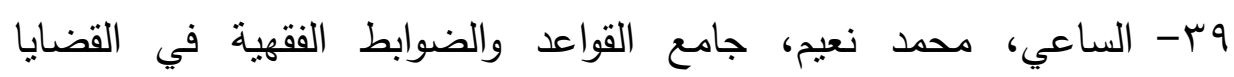

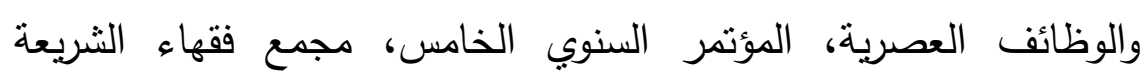
بأمريكيا، البحرين، تحت عنوان ويحل لهم الطيبات ويحرم عليهم الخبائث،

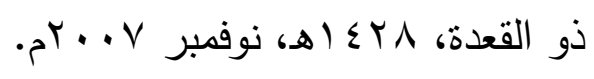

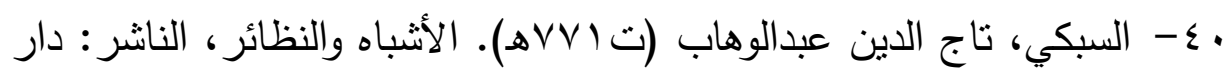

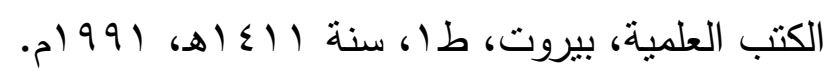

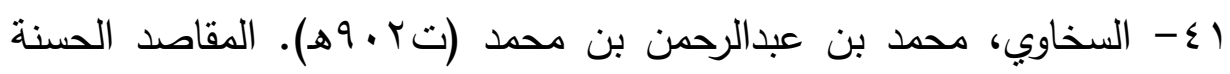

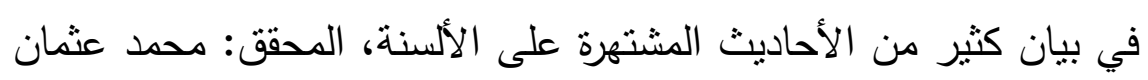




\section{د. د خالا سالم العازمي}

الخشت، الناشر: دار الكتاب العربي، بيروت، طا، سنة 0.ـ اهـ،

$$
\text { . ) } 910
$$

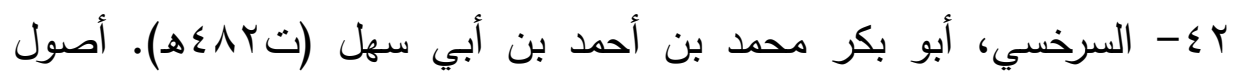
السرخسي، تحقيق: أبي الوفا الأفغاني، الناشر : دار المعرفة، بيروت، لبنان،

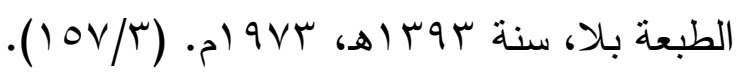

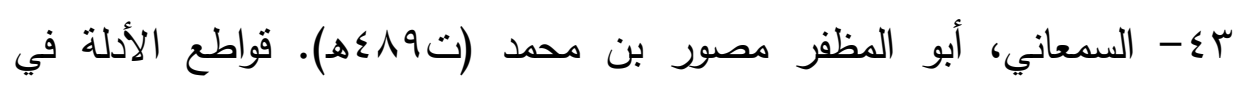
الأصول، تحقيق: محمد حسن محمد حسن الثافعي، الناشر: دار الكتب

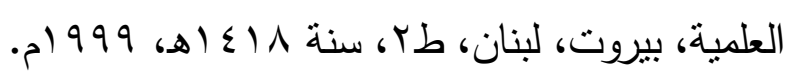

§ - السيوطي، جلال الدين عبدالرحمن بن أبي بكر (ت (19هـ)، الدرر المنتثرة في الأحاديث المشتهرة، تحقيق: الدكتور محمد بن لطفي الصباغ، الناشر: عمادة شؤون المكتبات، جامعة الملك سعود، الرباض. 0ـ- السيوطي، جلال الدين عبدالرحمن بن أبي بكر (ت الو9ه)، الأشباه والنظائر في قواعد وفروع فقه الثافعي، الناشر: دار الكتب العلمية،

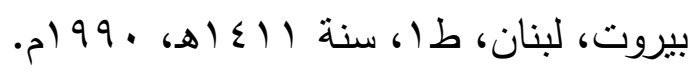

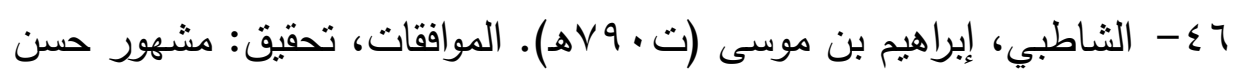

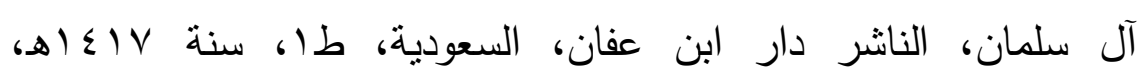

$$
\text { - ) } 99 \mathrm{~V}
$$

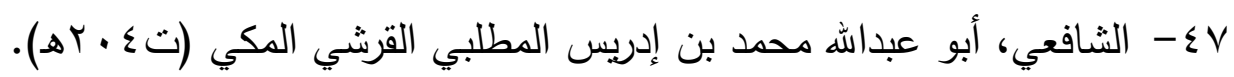

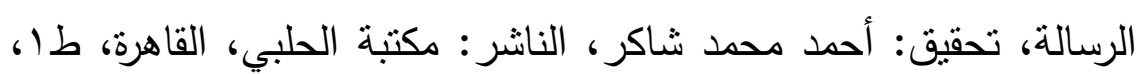

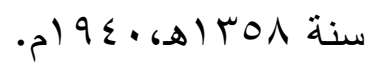

^乏 - الثربيني الخطيب، محمد بن أحمد (ت وVVه). مغني المحتاج إلى معرفة

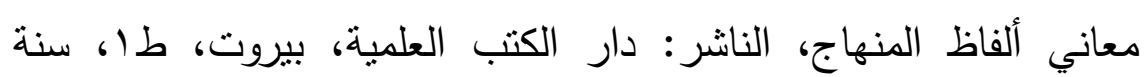




\section{اجتماع المال الحلال بالحرام}

9ะ- الشعلان، عبدالرحمن. المستثنيات من القواعد الفقهية أنواعها والقياس عليها، بحث منشور في مجلة جامعة أم القرى لعلوم الثريعة واللغة العربية

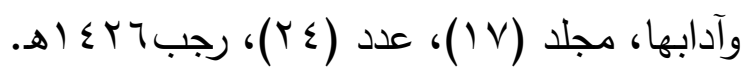

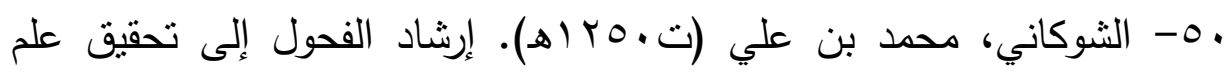

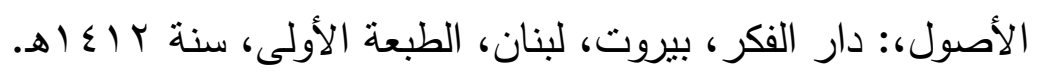

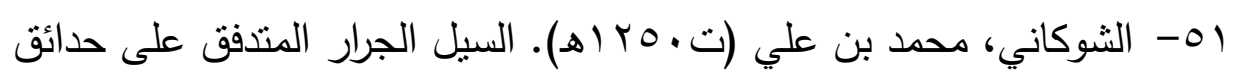

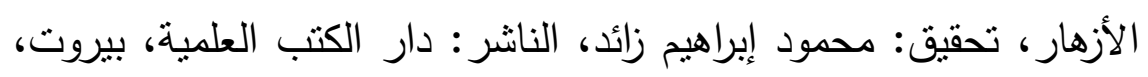

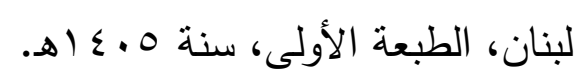

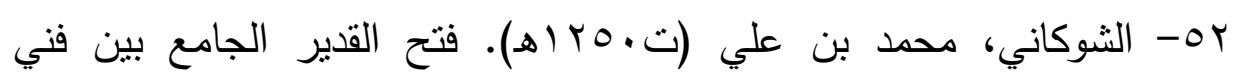

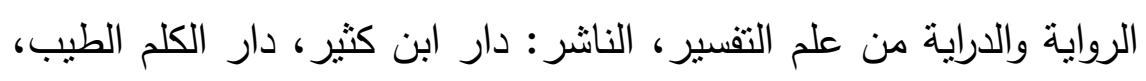

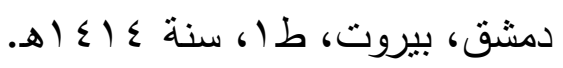

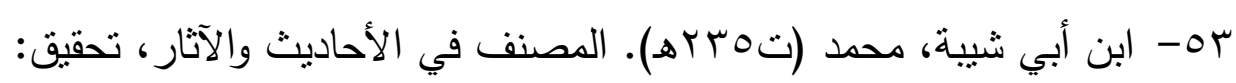

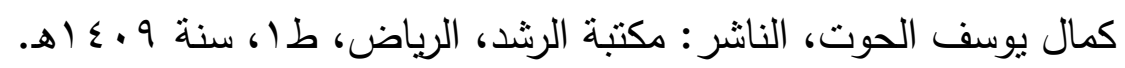

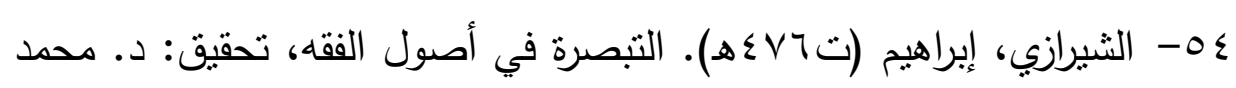

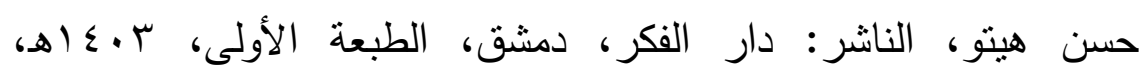

$$
\text { . } 91 \text {. }
$$

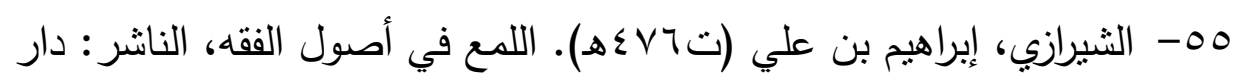

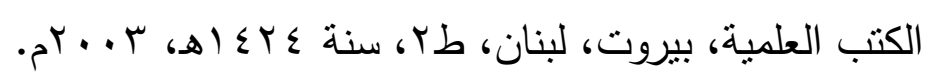

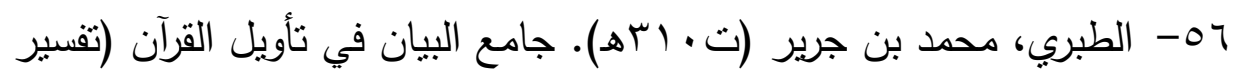

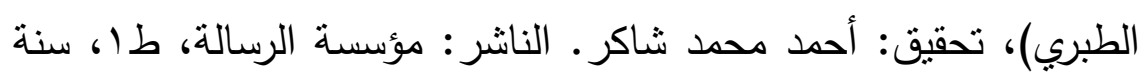

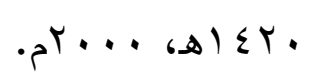

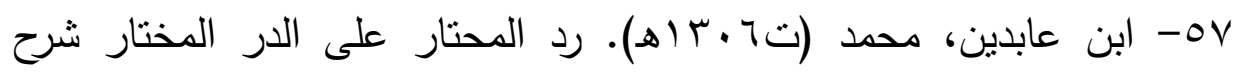

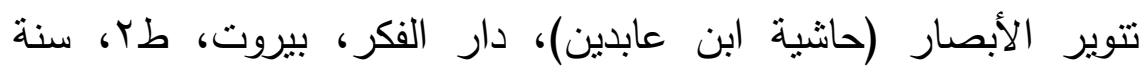


د. د خالا سالم العازمي

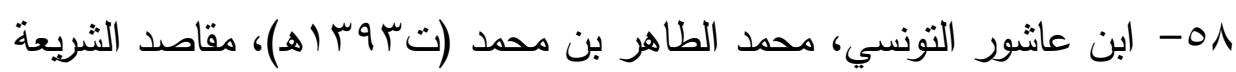
الإسلامية، المحقق: محمد الحبيب ابن الخوجة، الناشر: وزارة الأوقاف

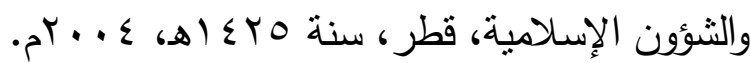

90- عبدالرزاق الصنعاني (ت ا آهـ). المصنف، تحقيق: حبيب الرحمن الأعظمي، الناشر: المجلس العلمي، الهند، بطلب من: المكتب الإسلامي،

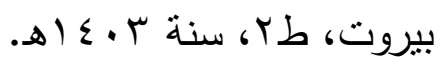

• ؟- بني عبدالله، يحيى موسى حمد. القواعد الفقهية في اجتماع الحلال والحرام وتطبيقاتها المعاصرة، رسالة دكتوراه في الفقه وأصوله، الجامعة الأردنية،

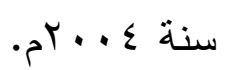

آ- ابن العربي المالكي، محمد (ت ا؟گهـ). أحكام القرآن، تحقيق: محمد عبدالقادر عطا، الناشر: دار الكتب العلمية، بيروت، لبنان، ط؟، سنة

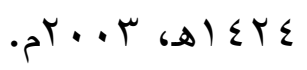

ץT- ابن عرفة التونسي، محمد بن محمد (تץ.^هـ). المختصر الفقهي، تحقيق: حافظ عبدالرحمن خير، الناشر: مؤسسة خلف أحمد الخبتور

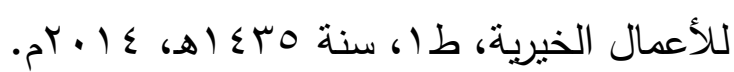
با7- عزالدين ابن عبدالسلام، عبدالعزيز (ت . 77هـ). قواعد الأحكام في مصالح

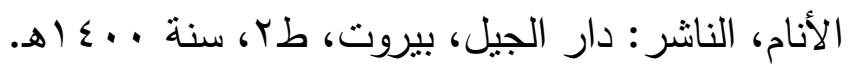
§ ا- ابن عطية، عبدالحق بن غالب (ت بـهـ). المحرر الوجيز في تفسير الكتاب العزيز (تفسير ابن عطية)، الناشر: دار الكتب العلمية، بيروت،

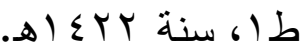
07- العظيم آبادي، أبو الطيب محمد شمس الدين (ت • اب اهـ)، عون المعبود شرح سنن أبي داود، الناشر: دار الكتب العلمية، بيروت، لبنان، الطبعة الثانية، سنة 0 إ إهـ. 


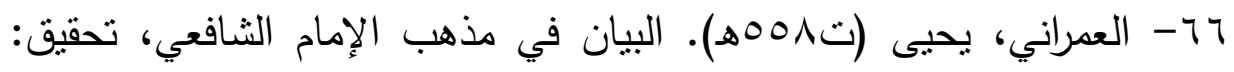

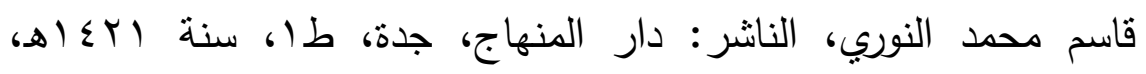

$$
\text { . }
$$

VT- العيني، محمود بن أحمد (ت100هـ). البناية شرح الهداية، النانر : دار

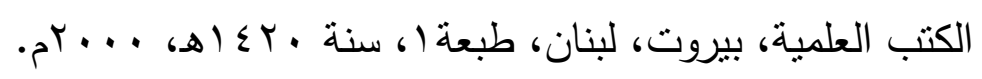

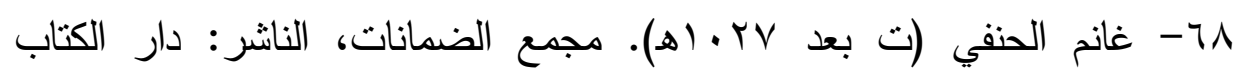

الإسلامي، ط بلا، سنة بلا.

79- الغزالي، أبو حامد محمد بن محمد بن محمد (ته ب.0هـ). إحباء علوم

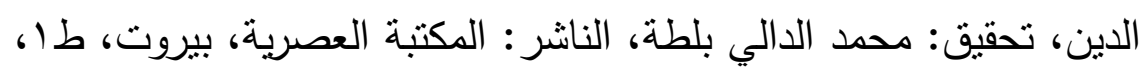

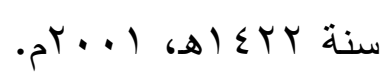

• .

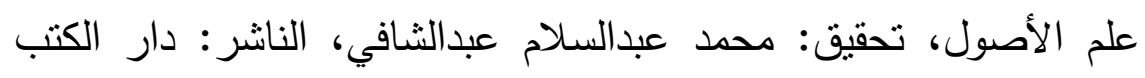

العلمية، بيروت، لبنان، طا، سنة سا إع الهـ

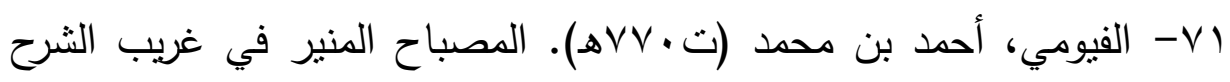

الكبير ، المكتبة العلمية، بيروت، ط بلا، سنة بلا.



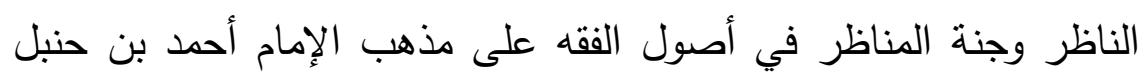

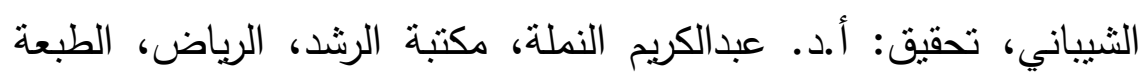

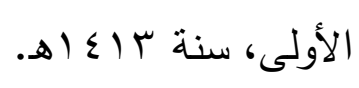

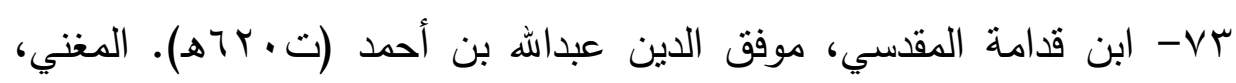

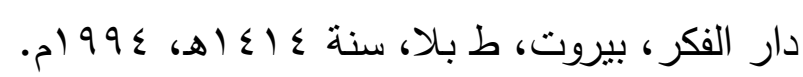

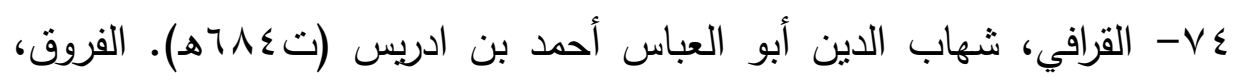
الناشر : عالم الكتب، بيروت، ط بلا، سنة بلا. 


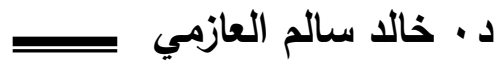

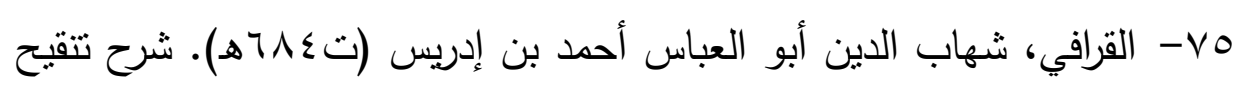
الفصول، تحقيق: طه عبدالرؤوف سعيد، الناشر: شركة الطباعة الفنية

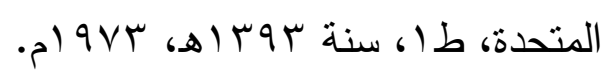

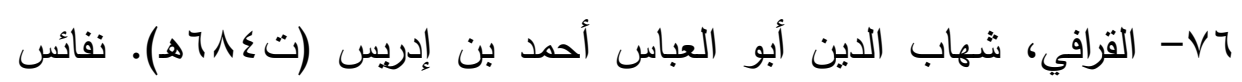
الأصول في شرح المحصول، المحقق: عادل أحمد عبدالموجود، علي

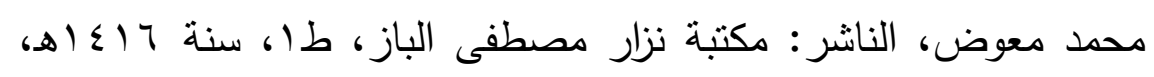
- $) 990$

-VV القرطبي، محمد بن أحمد (ت التهـ). الجامع لأحكام القرآن (تفسير

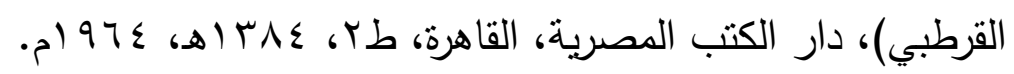
^ - القره داغي، علي محيي الدّين. الأسوَاق المالِيَّة في مِيزان الفقه الإسلامي، مجلة مجمع الفقه الإسلامي.

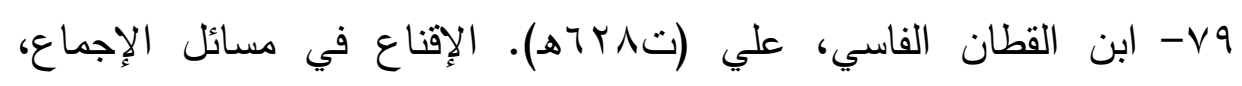

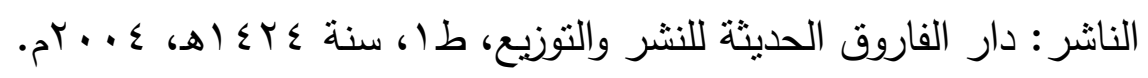
• ^- قليوبي، أحمد (ت997 . (ه) وعميرة، أحمد (ت 90Vه). حاشيتا قليوبي وعميرة، الناشر : دار الفكر، بيروت، ط بلا، سنة 0 اء أه، 990 ام.

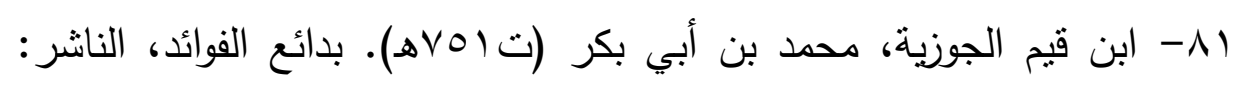
دار الكتاب العربي، بيروت، لبنان.

r

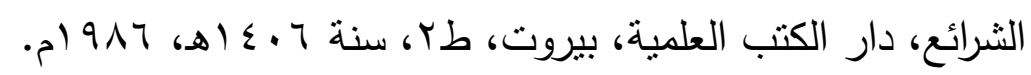
بر- ابن اللحام الدمشقي الحنبلي، علي المعروف بابن اللحام (ت •ـهـ). القواعد والفوائد الأصولية وما يتبعها من الأحكام الفرعية، تحقيق: محمد بائ حامد الفقي، الناشر: دار الكتب العلمية، بيروت، لبنان، الطبعة الأولى،

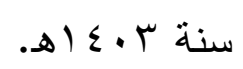




\section{اجتماع المال الحلال بالحرام}

عـ- مالك بن أنس (تولاهـ). الموطأ، تحقيق: محمد فؤاد عبدالباقي، الناشر:

دار إحياء التراث، مصر ، الطبعة بلا، سنة الطبع بلا.

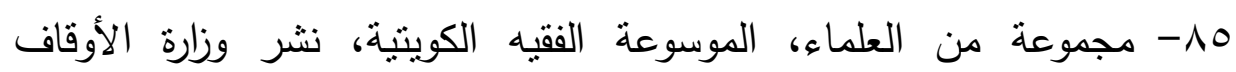

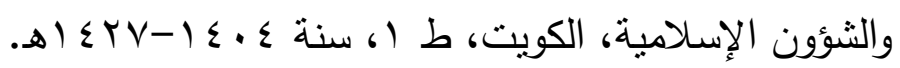

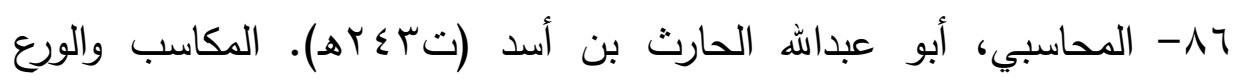

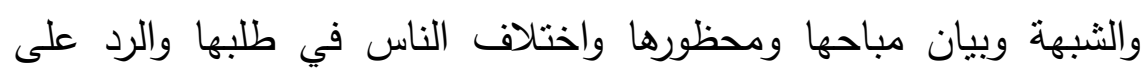
الغالطين فيه، المحقق: نور سعيد، الناشر: دار الفكر اللبناني، بيروت، وانيا

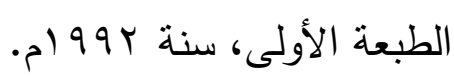

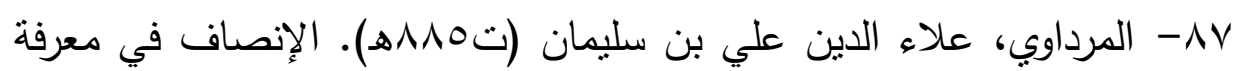

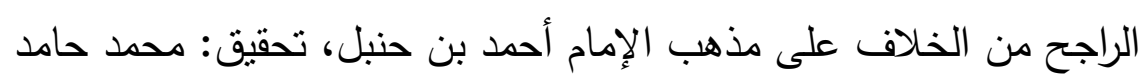

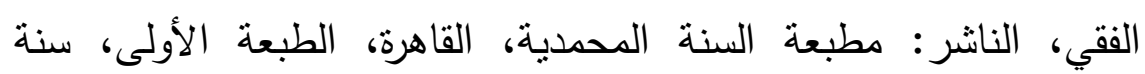

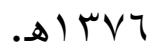

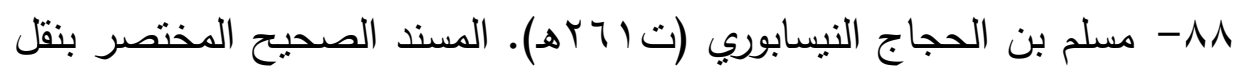

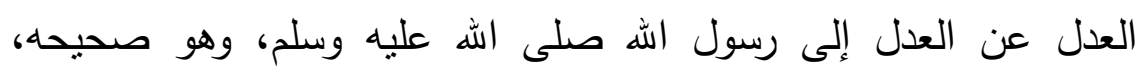

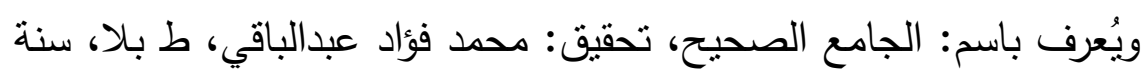

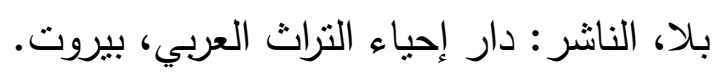

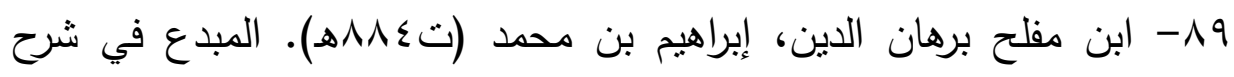

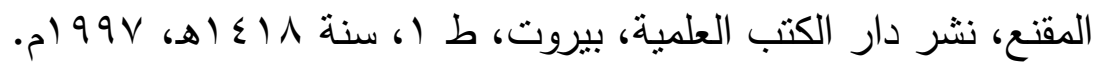

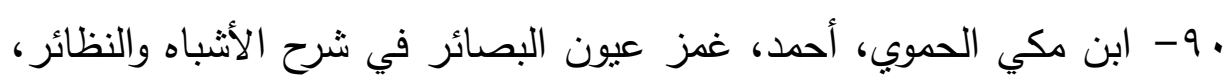

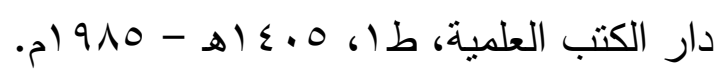

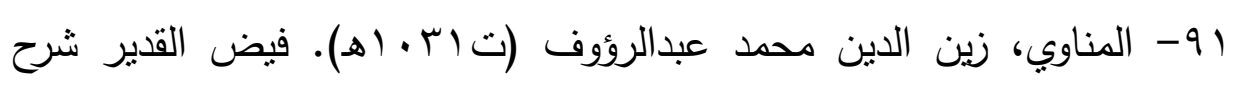

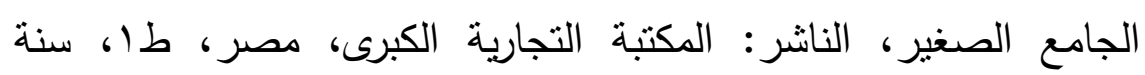




\section{د. د خالد سالم العازمي}

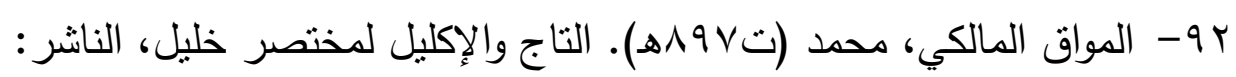

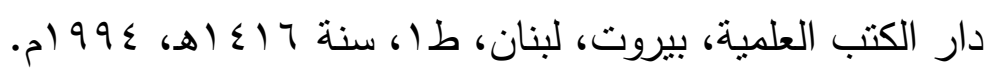

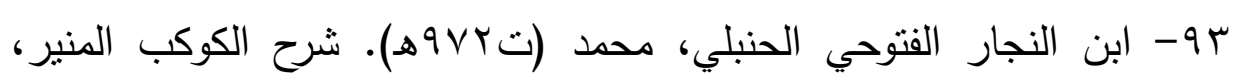
المسمى بمختصر التحرير، تحقيق: محمد الزحيلي، ونزيه حماد، الناشر: جامعة أم القرى، معهد البحوث العلمية وإحياء التراث الإسلامي، مكة

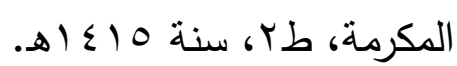

ع - ابن نجيم، زين الدين (ت • V هـ). الأشباه والنظائر على مذهب أبي حنيفة النعمان، وضع حواثيه وخرج أحاديثه: زكريا عميرات، الناشر: دار الكتب التباه

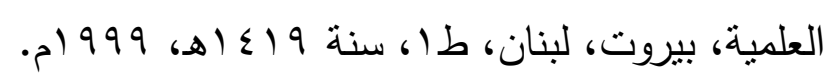
9- النذوي، علي أحمد. القواعد الفقهية مفهومها نشأنها تطورها دراسة مؤلفاتها

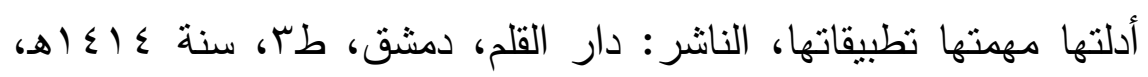

$$
\text { - P) } 99 \leq
$$

97- ابن هبيرة، يحيى (ت. ب0 هـ). اختلاف الأئمة العلماء، تحقيق: السيد

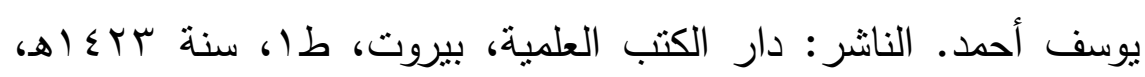

$$
\cdot r^{2} \cdot r
$$

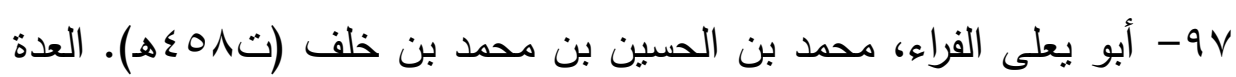
في أصول الفقه، تحقيق: د. أحمد بن علي بن سير المباركي، الناشر:

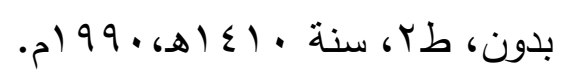

^9- اليوسف، صالح. قاعدة إذا اجتمع الحلال والحرام غلب الحرام، مركز البحوث في كلية الشريعة والدراسات الإسلامية، جامعة القصيم. 9 9- ابن يونس الصقلي، أبو بكر محمد بن عبداله (ت ال0ـهـ). الجامع لمسائل المدونة، تحقيق: مجموعة باحثين في رسائل دكتوراه، الناشر : معهد البحوث العلمية وإحياء التراث الإسلامي، جامعة أم القرى، مكة المكرمة، نوزيع:

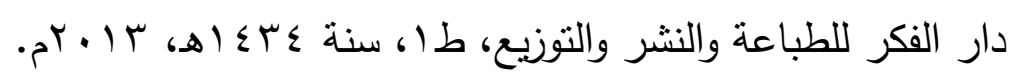




\section{=}

الهوامش:

(1) الثافعي، أبو عبداله محمد بن إدريس المطلبي القرشي المكي (تى • بهـ). الرسالة،

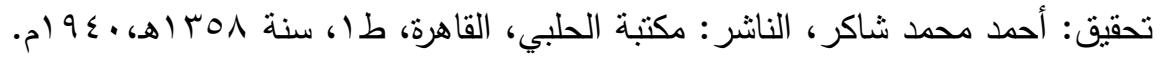

$$
\text { (ص) ( }
$$

(بدر، علي. شرح مجلة الأحكام العدلية، تعريب: فهمي الحسيني، نشر: دار الجيل،

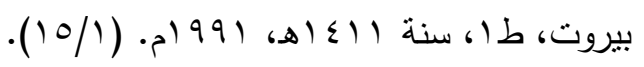

(r) الغزالي، أبو حامد محمد بن محمد بن محمد (ته (0ه). إحياء علوم الدين، تحقيق:

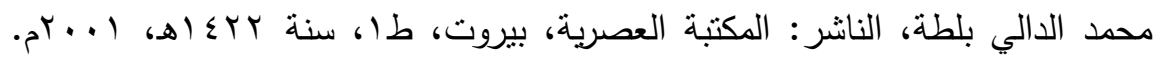

$$
(\mid V) / Y)
$$

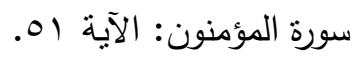

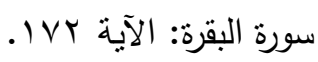

(7) أخرجه مسلم بن الحجاج النيسابوري (ت آبآهـ). المسند الصحيح المختصر بنقل العدل

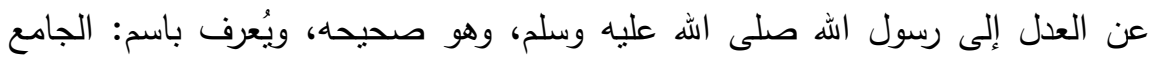
الصحيح، تحقيق: محمد فؤاد عبدالباقي، ط بلا، سنة بلا، الناشر : دار إحياء التراث

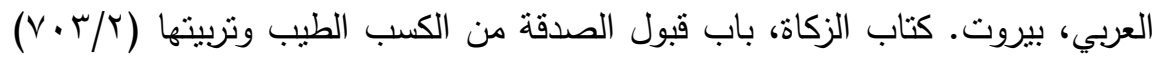

$$
\text { حديث رقم (10 • (1)). }
$$

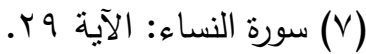$$
\text { (^) سورة البقرة: الآية (AV9) }
$$

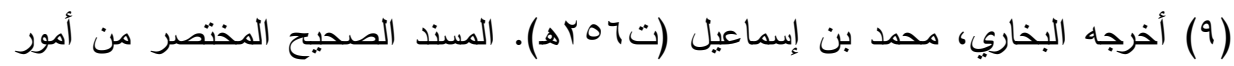
رسول الله صلى الله عليه وسلم وسننه وأيامه، وهو صحيحه، ويُعرف باسم: الجامع الصحيح، تحقيق: محمد زهير الناصر، الناشر: دار طوق النجاة، طا، سنة بrك اهـ.

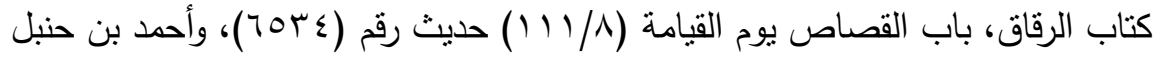

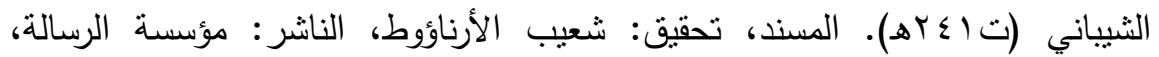

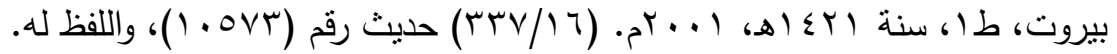

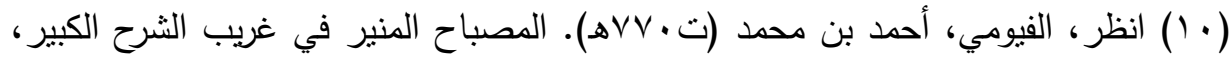
المكتبة العلمبة، بيروت، ط بلا، سنة بلا. (ץ/· (0)، وابن عاثشور التونسي، محمد الطاهر بن محمد (ت بهو (اه)، مقاصد الثريعة الإسلامية، المحقق: محمد الحبيب ابن 
د · · خالد سالم العازمي

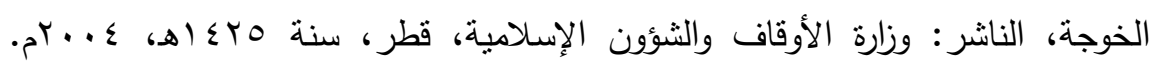

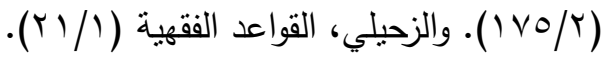

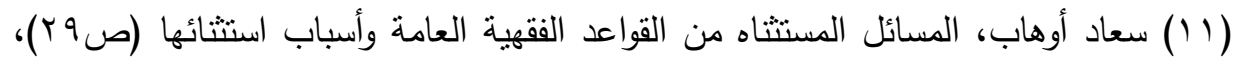

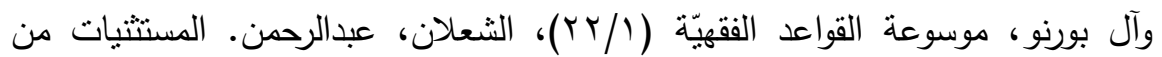
القواعد الفقهية أنواعها والقياس عليها، بحث منشور في مجلة جامعة أم القرى لعلوم

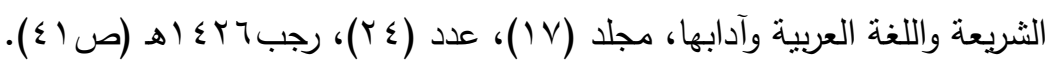

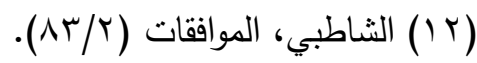

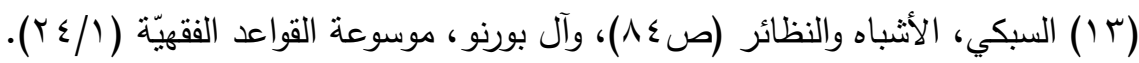

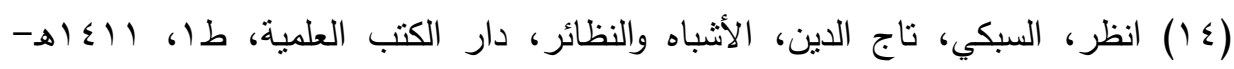

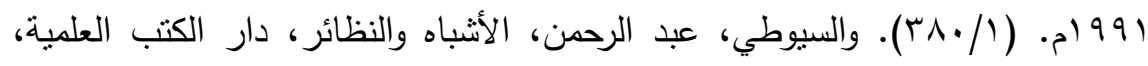

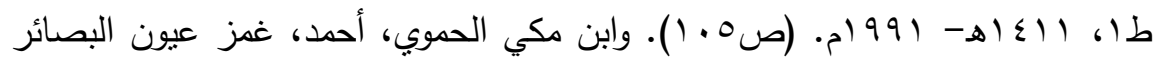

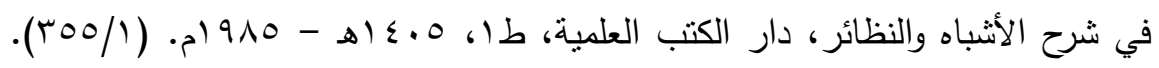

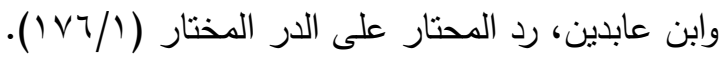

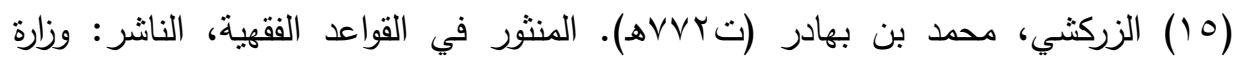

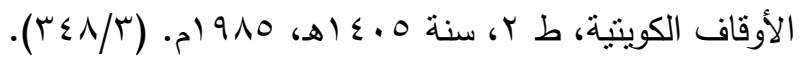

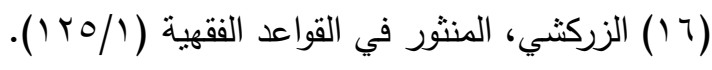

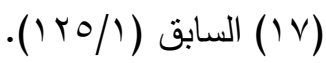

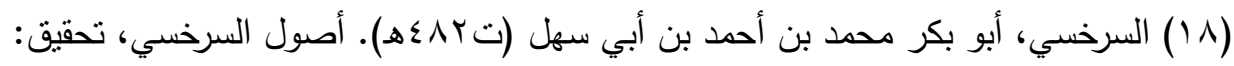

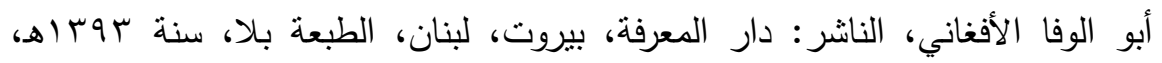

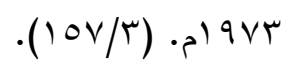

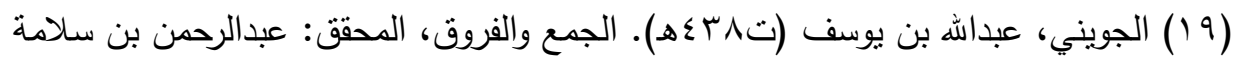

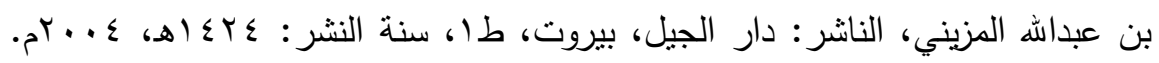
. (OrN/r)

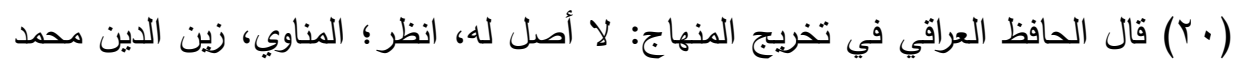

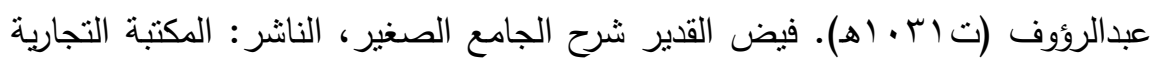

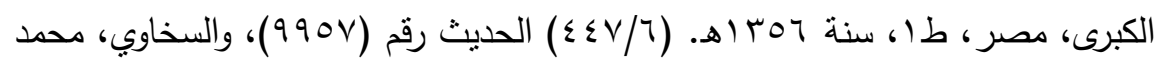
بن عبدالرحمن بن محمد (ت .9ه). المقاصد الحسنة في بيان كثير من الأحاديث 
المشتهرة على الألسنة، الححق: محمد عثمان الخشت، الناشر: دار الكتاب العربي،

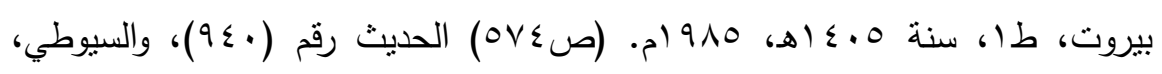

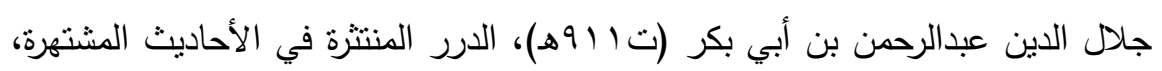

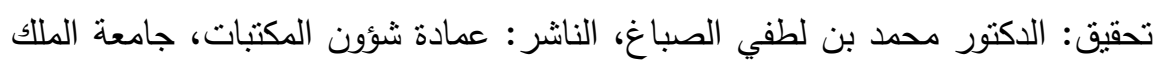

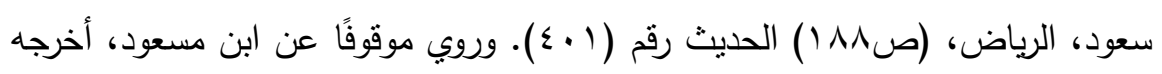

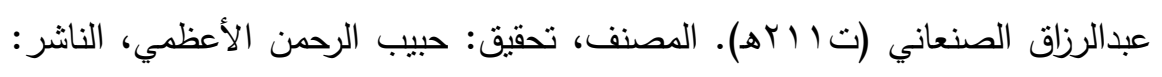

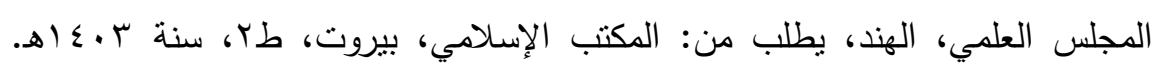

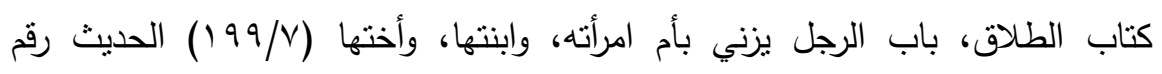
(I YVRT)

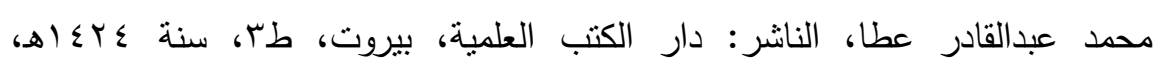

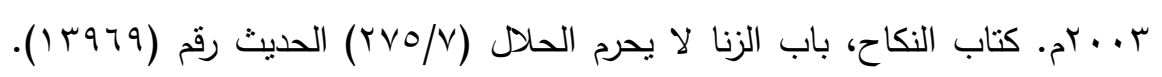

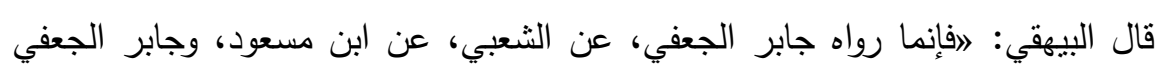

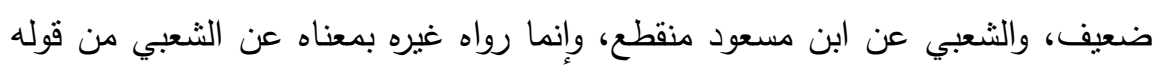
غير مرفوع إلى عبد الله بن مسعودها.

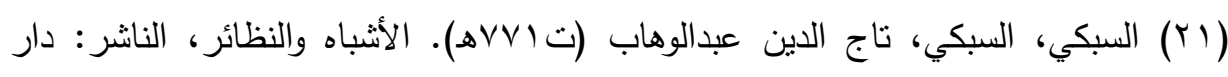

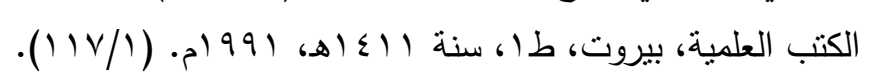

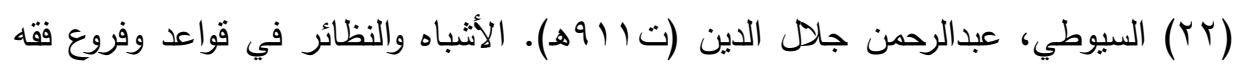

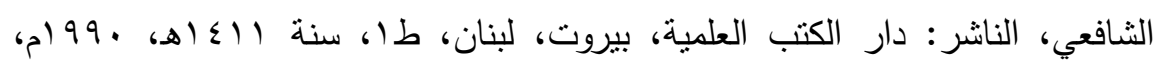

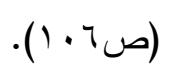

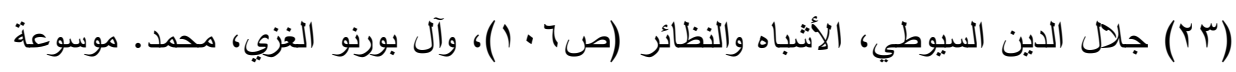

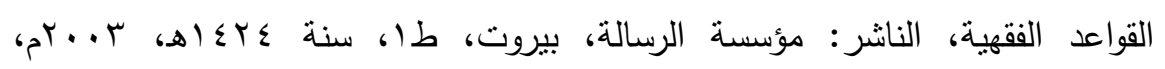

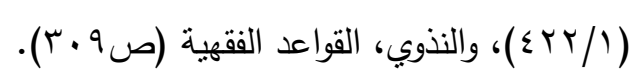

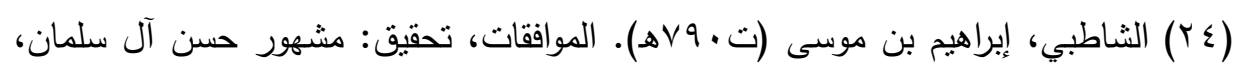

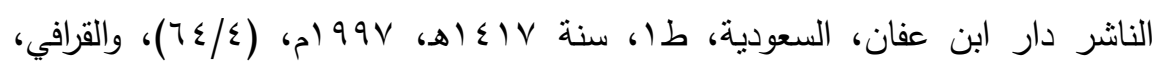

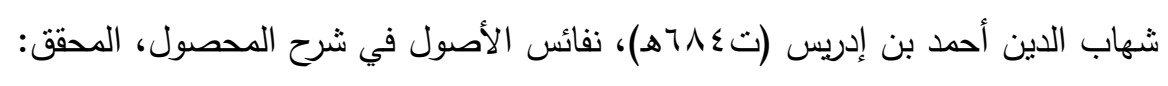

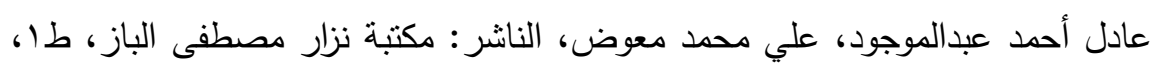

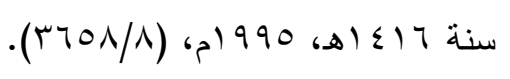


د · خ خالد سالم العازمي ـــ

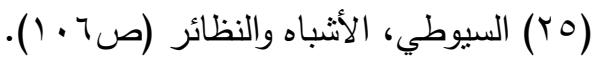

(YT) بني عبدالله، القواعد الفقهية في اجتماع الحلال والحرام وتطبيقاتها المعاصرة (ص99)

$$
\text { وما بعدها. }
$$

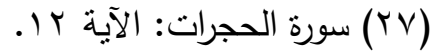

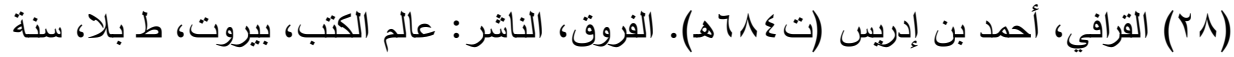

$$
\text { بلا. (lv/r) }
$$

(Y9) رواه البخاري، كتاب البيوع، باب الحلال بين، والحرام بين، وبينهما مشبهات (r/\%)

الحديث رقم (1.01)، ومسلم، كتاب المساقاة، باب أخذ الحلال وترك الثبهات

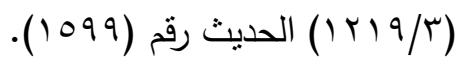

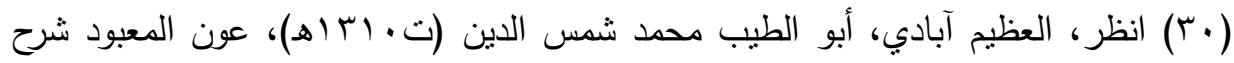

سنن أبي داود، الناثر : دار الكتب العلمية، بيروت، لبنان، الطبعة الثانبة، سنة 1 إ اله.

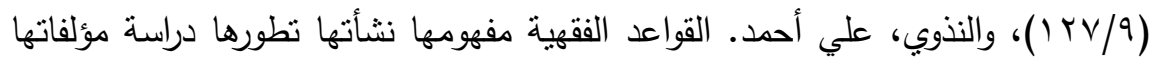

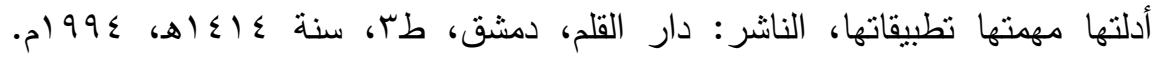

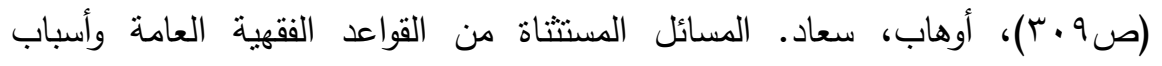

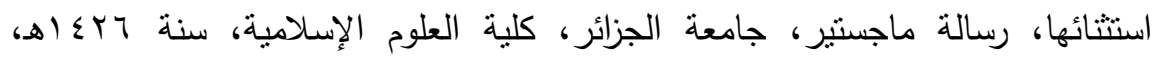

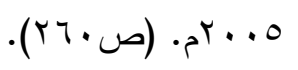

(1) السيوطي، الأشباه والنظائر (صل ( ـ () وما بعدها، وينظر : اليوسف، صالح. قاعدة إذا اجتمع الحلال والحرام غلب الحرام، مركز البحوث في كلية الثريعة والدراسات الإسلامية،

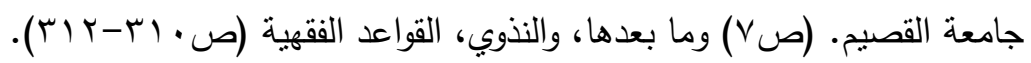

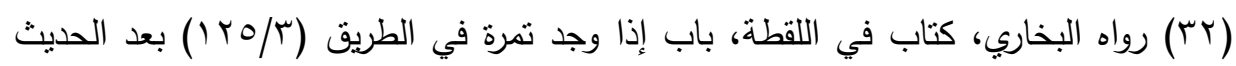

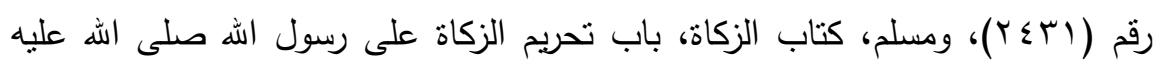

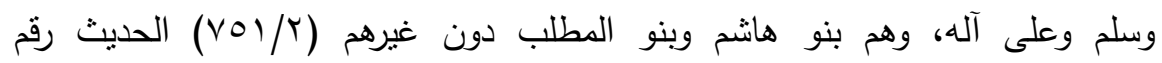
$\cdot(1 \cdot v \cdot)$

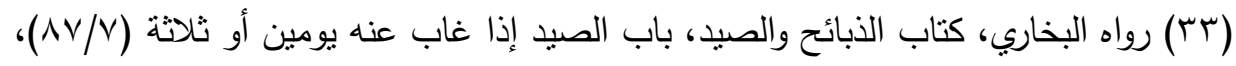

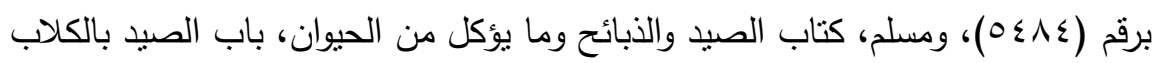

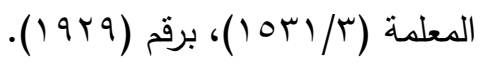




\section{اجتماع المال الحلال بالحرام}

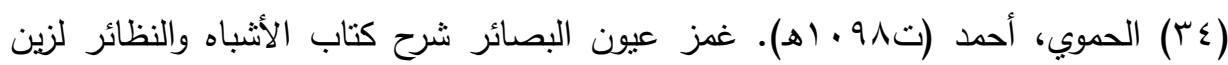

العابدين ابن نجيم المصري، الناشر: دار الكتب العلمية، لبنان، بيروت، طا، سنة

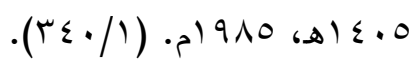

(Y0) رواه مالك بن أنس (تو V (ه). الموطأ، تحقيق: محمد فؤاد عبدالباقي، الناشر : دار إحباء

التراث، مصر، الطبعة بلا، سنة الطبع بلا. كتاب النكاح، باب ما جاء في كراهية إصابة

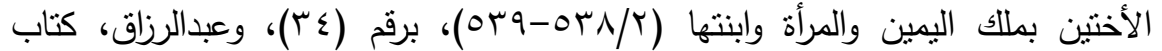

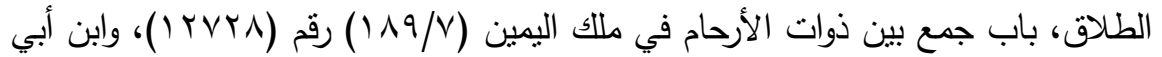

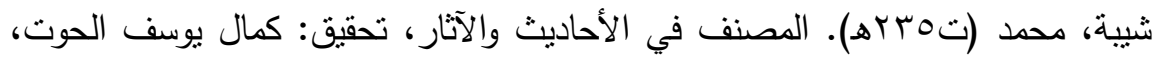
الناشر : مكتبة الرشد، الرياض، طا، سنة 9 ــ اهـ. كتاب النكاح، باب الرجل يكون عنده

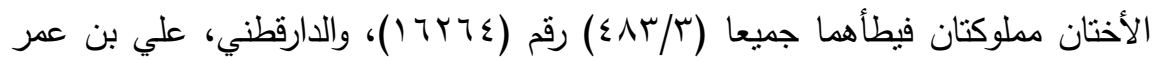

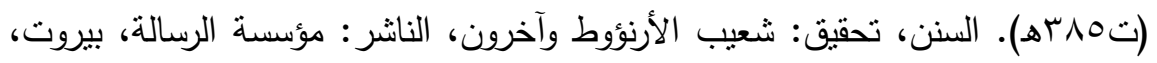

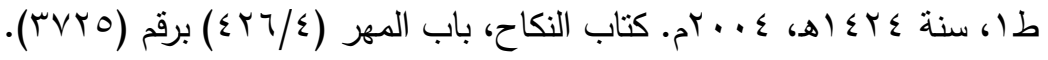

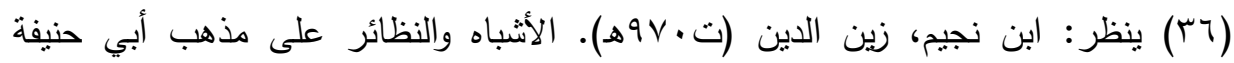
النعمان، وضع حواثيه وخرج أحاديثه: زكريا عميرات، الناشر: دار الكتب العلمية، لهنية

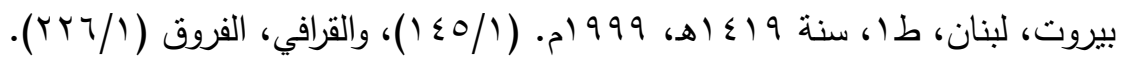

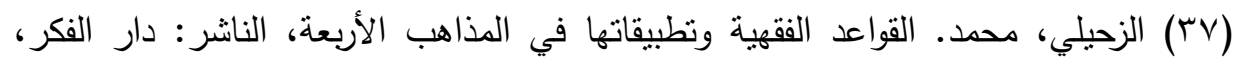

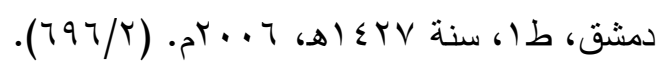

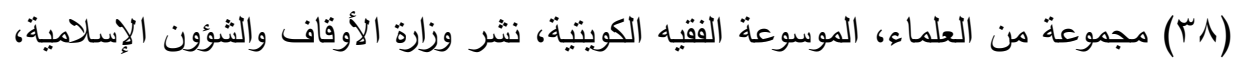

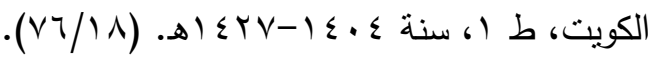

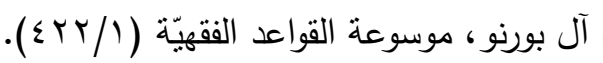

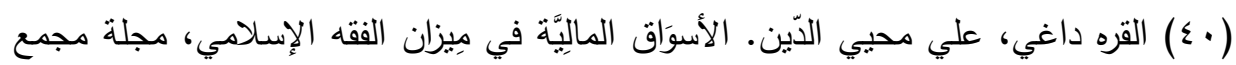

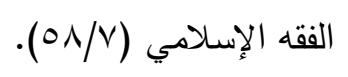

(1) بني عبداله، يحيى موسى حمد. القواعد الفقهية في اجتماع الحلال والحرام وتطبيقاتها

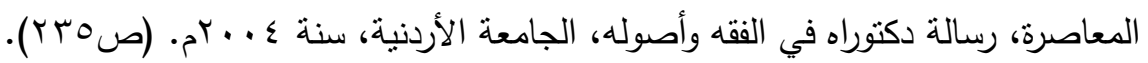

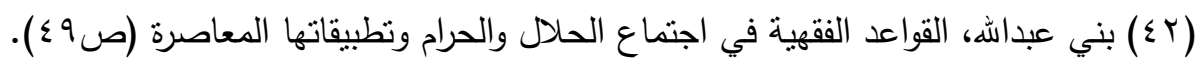

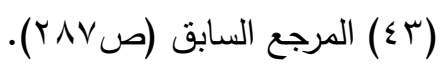




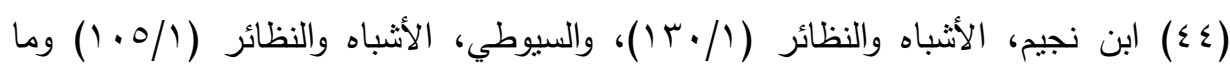

$$
\text { بعدها. }
$$

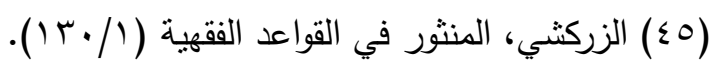

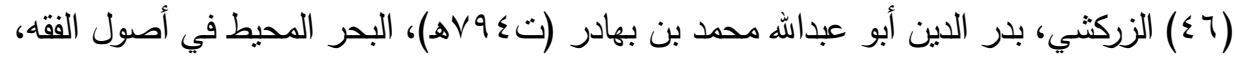

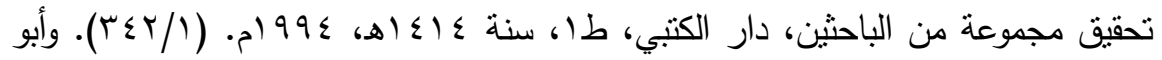
يعلى الفراء، محمد بن الحسين بن محمد بن خلف (تمهـءه). العدة في أصول الفقه،

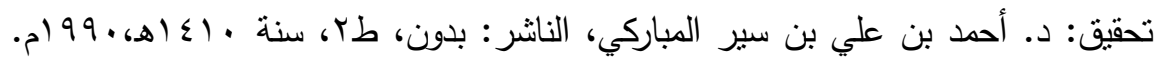

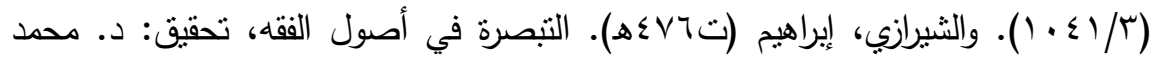

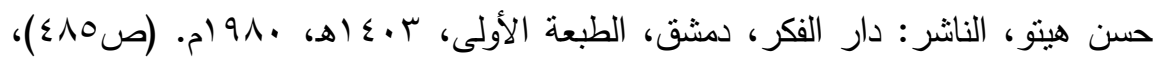

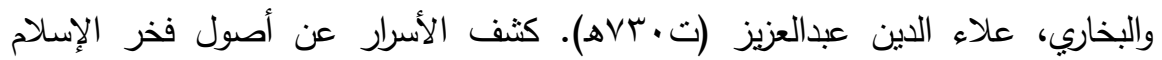
البزدوي، تحقيق: عبداله محمود محمد عمر، الناشر: دار الكتب العلمية، بيروت، لبنان،

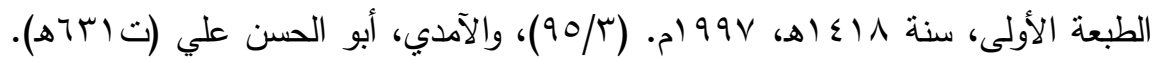

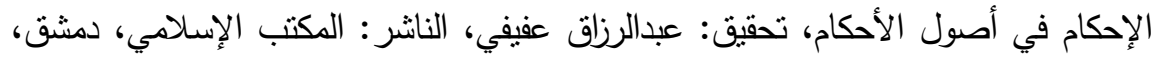

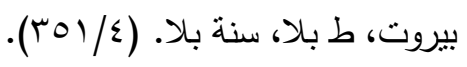

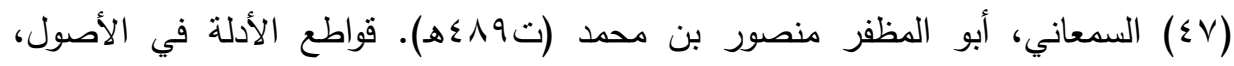
تحقيق: محمد حسن محمد حسن الثافعي، الناشر: دار الكتب العلمية، بيروت، لبنان،

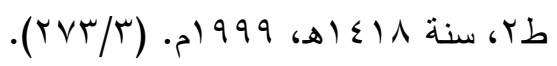

(1) الغزالي، أبو حامد محمد بن محمد بن محمد (ته . 0هـ). المستصفى في علم الأصول،

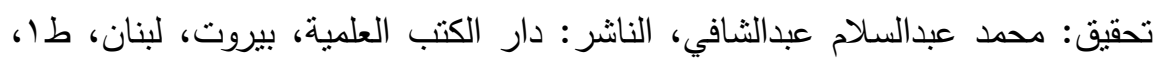

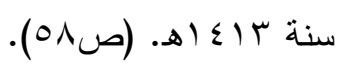

(9) الرازي، أبو عبداله محمد بن عمر (7 · 7هـ). الدحصول، تحقيق: طه جابر فياض

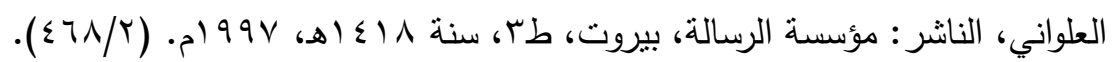

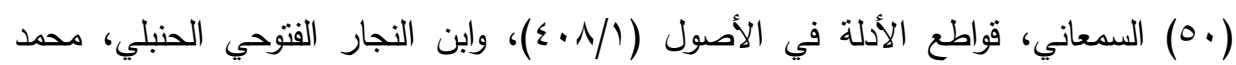

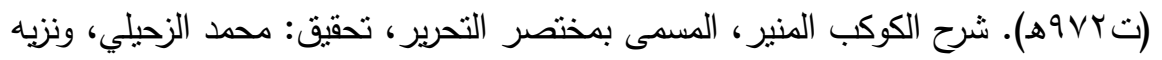

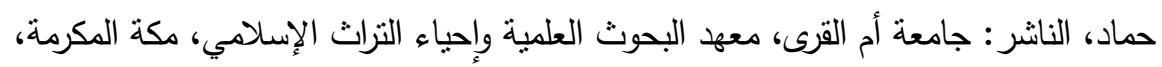

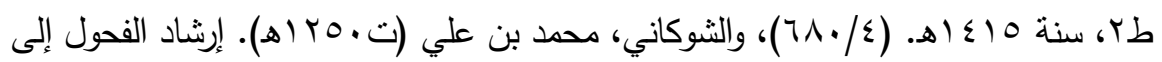

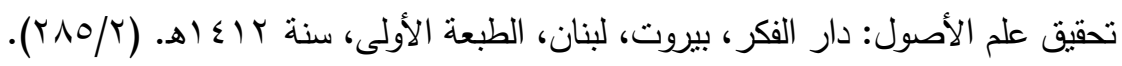




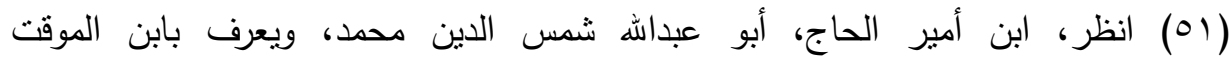

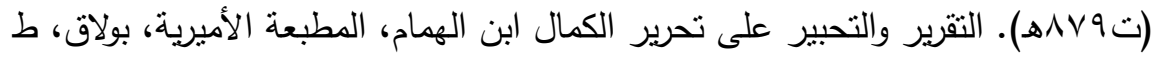

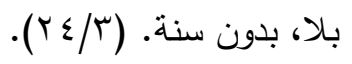

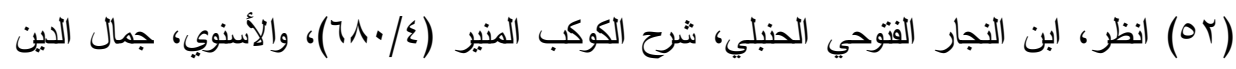

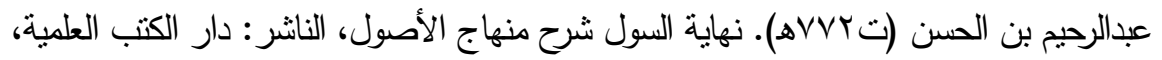

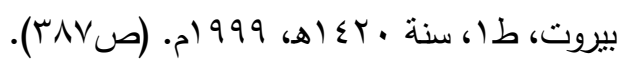

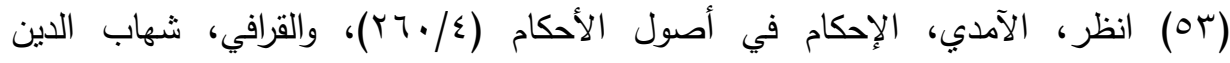

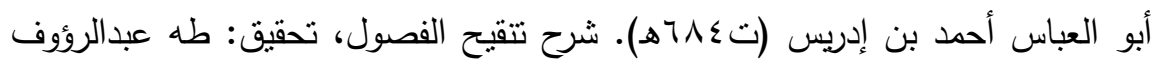

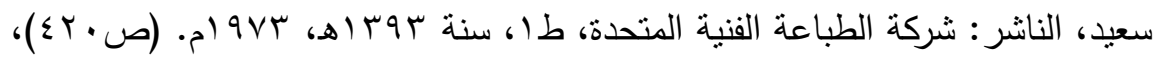

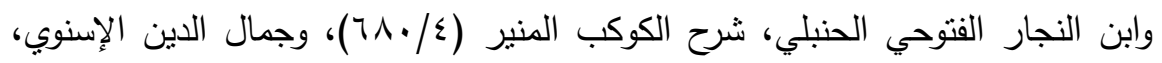

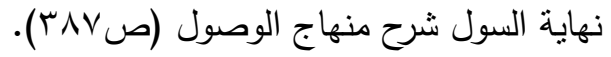

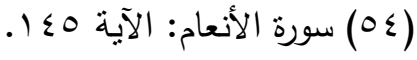

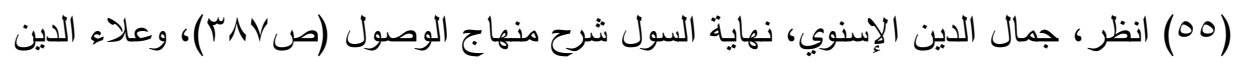

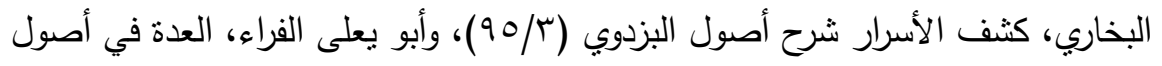

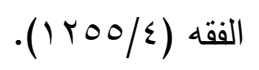

(7ه) رواه البخاري، كتاب الاعتصام بالكتاب والسنة، باب ما يكره من كثرة السؤال وتكلف ما

لا يعنيه (90/9)، رقم الحديث(Y) (VY9)، ومسلم، كتاب الفضائل، باب توقيره صلى الله عليه وسلم، وترك إكثار سؤاله عما لا ضرورة إليه، أو لا يتعلق به تكليف وما لا يقع،

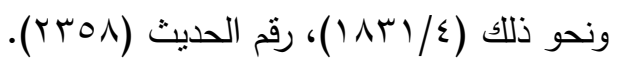

(OV) ابن قدامة المقدسي، موفق الدين عبداله بن أحمد (ت.rTه). روضة الناظر وجنة

المناظر في أصول الفقه على مذهب الإمام أحمد بن حنبل الثيباني، تحقيق: أ.د.

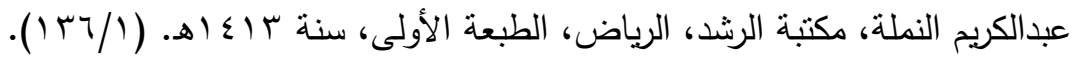

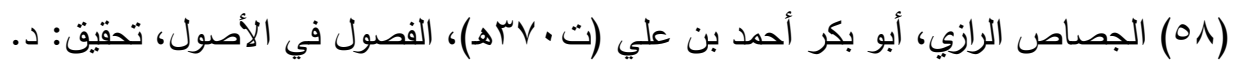

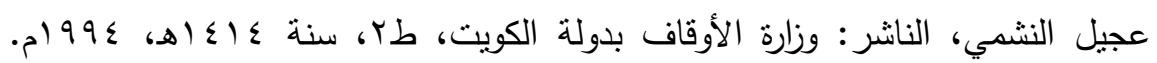
$\cdot(r \leq q / r)$ 


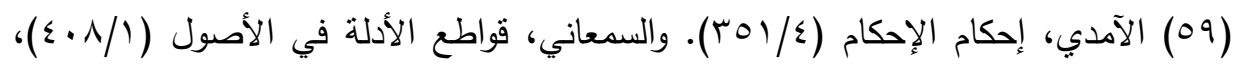

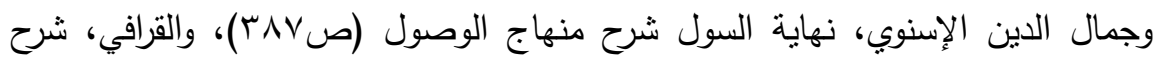

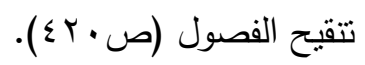

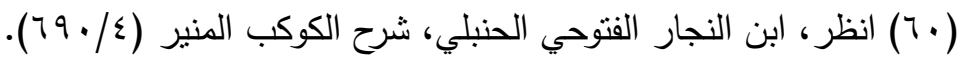

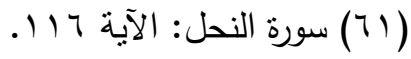

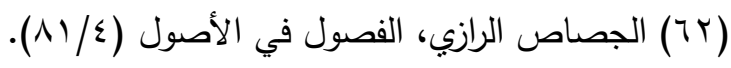

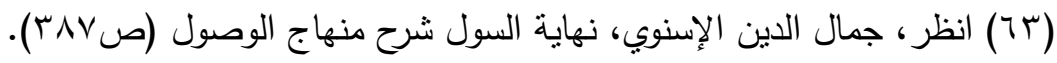

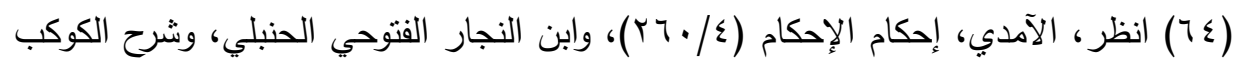

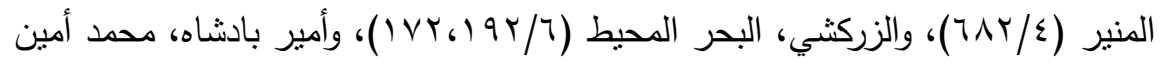

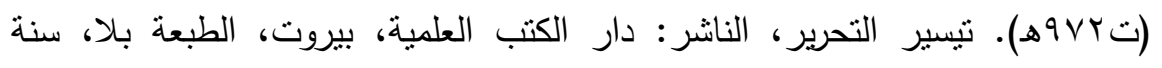

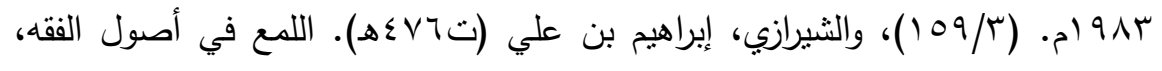

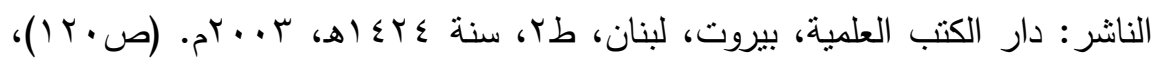

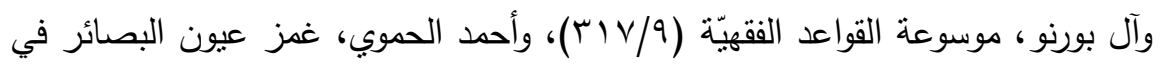

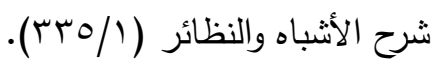

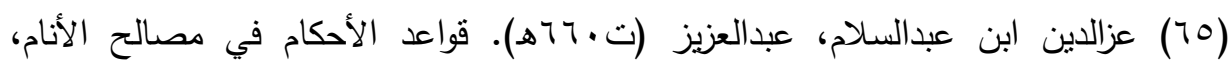

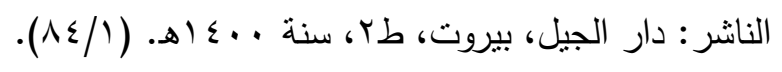

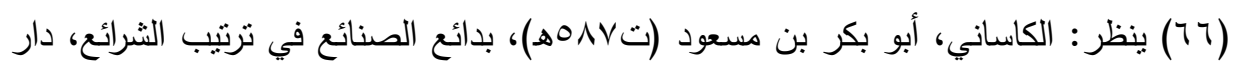

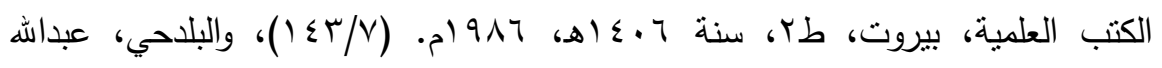

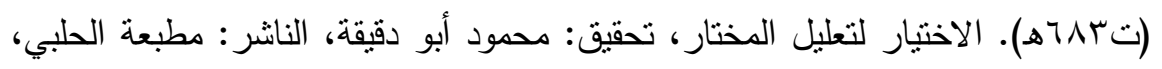

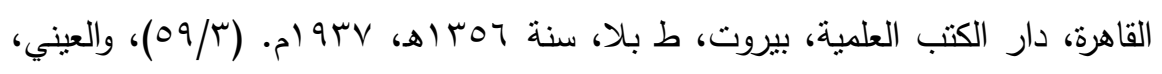

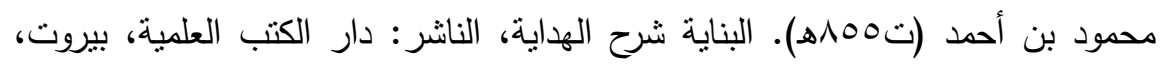

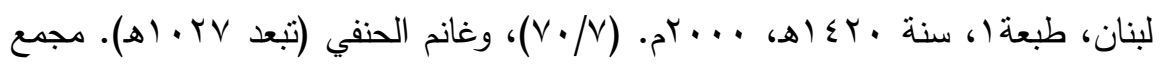

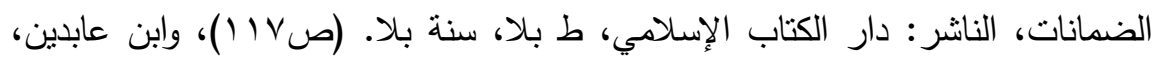

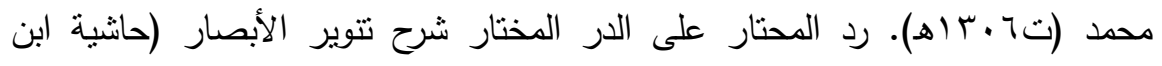

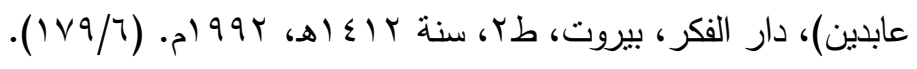

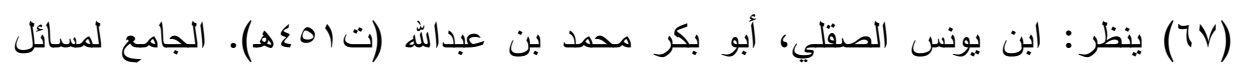

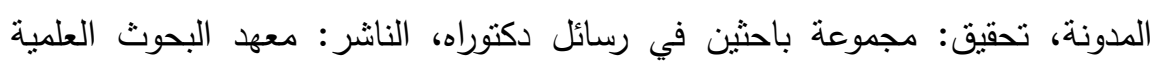




\section{اجتماع المال الحلال بالحرام}

وإحياء التراث الإسلامي، جامعة أم القرى، مكة المكرمة، نوزيع: دار الفكر للطباعة

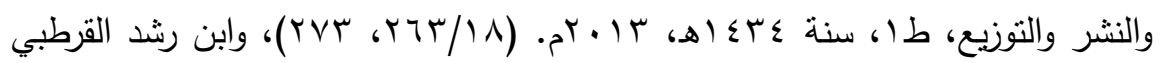

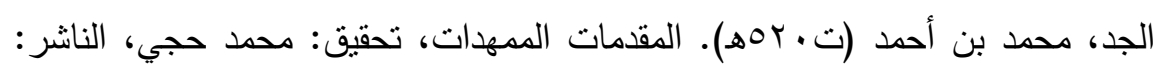

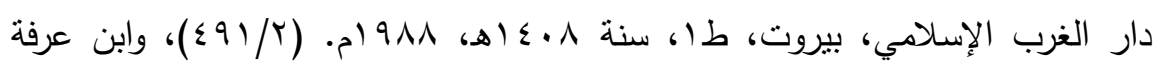

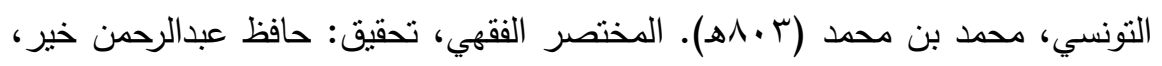

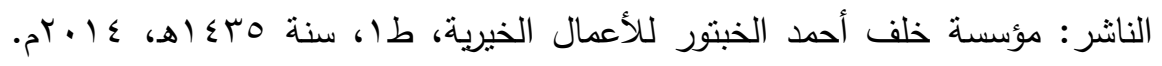
(YOA-YOV/V)

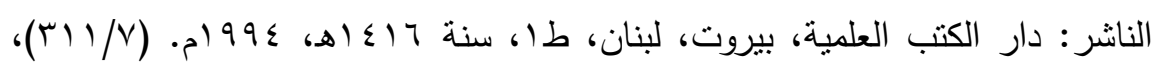

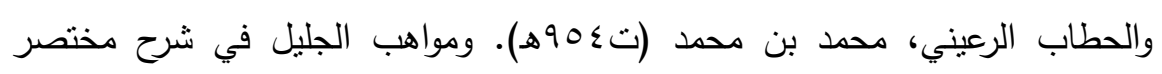

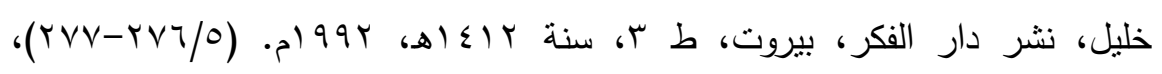

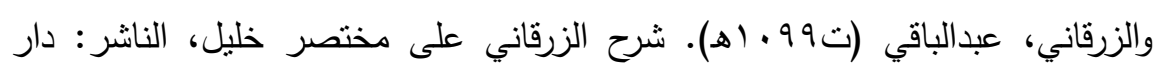

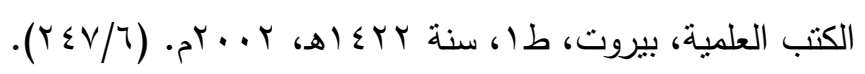

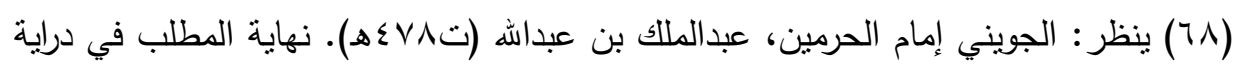

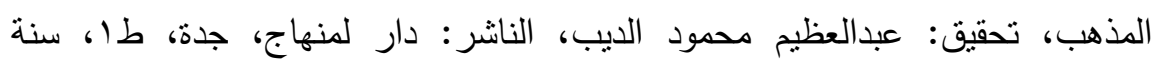

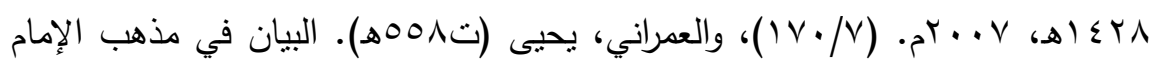

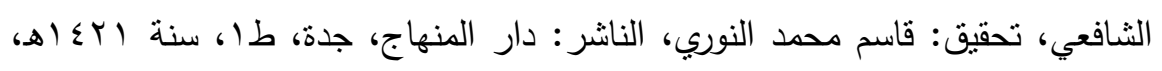

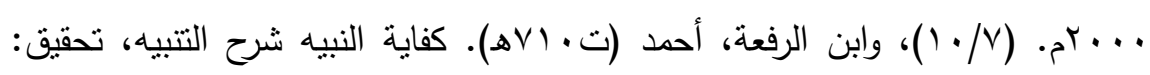

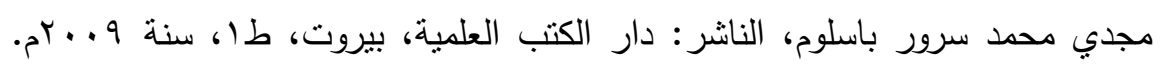

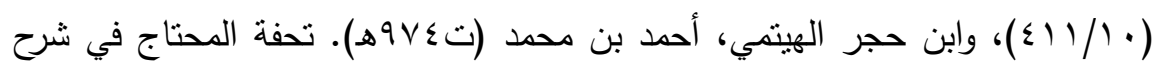

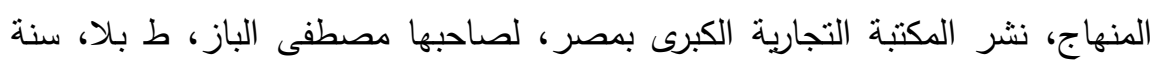

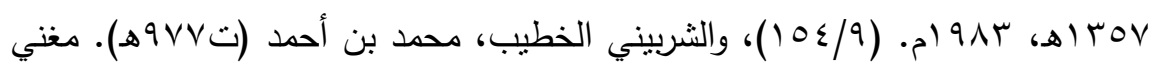

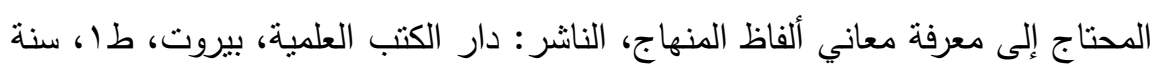

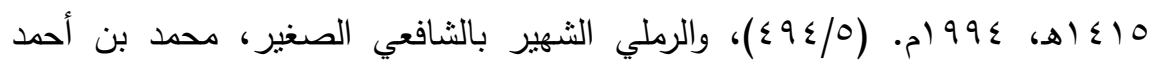

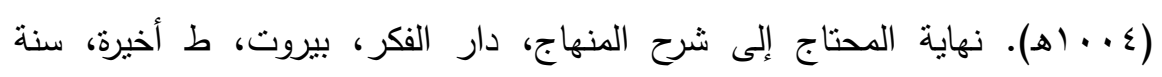

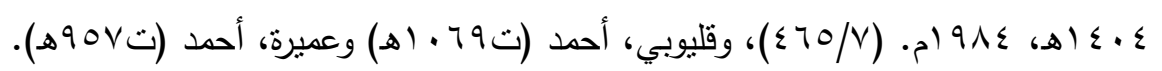

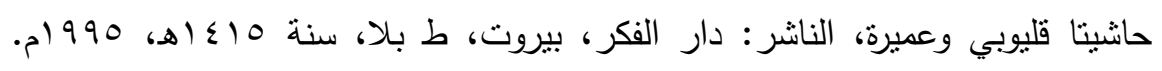


د · · خالد سالم العازمي لـ

(97) ابن قدامة المقدس، موفق الدين عبداله بن أحمد (ت • ب7هـ). المغني، دار الفكر ، بيروت،

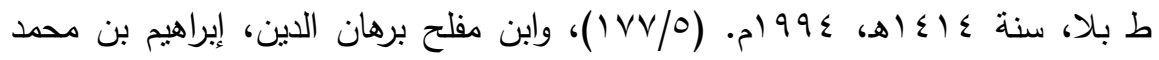

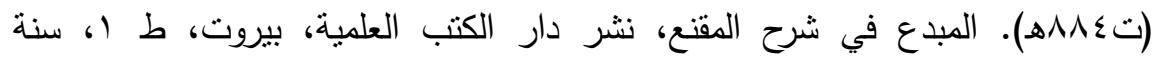

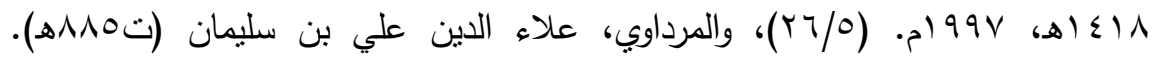

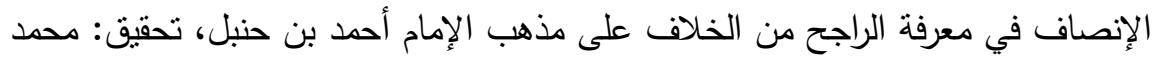

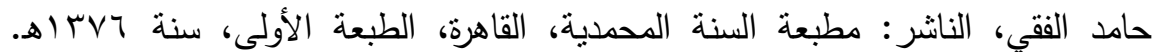

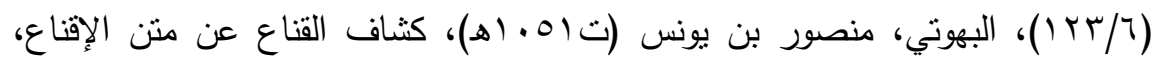

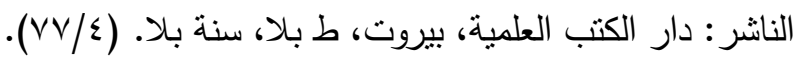

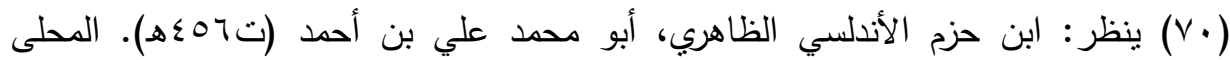

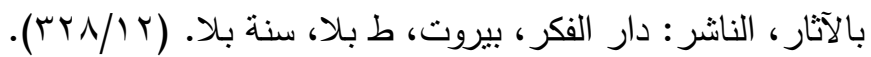

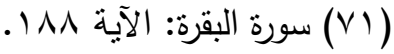

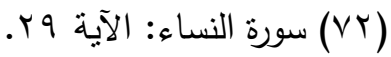

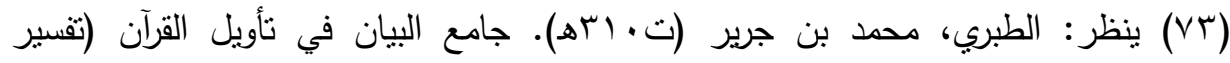

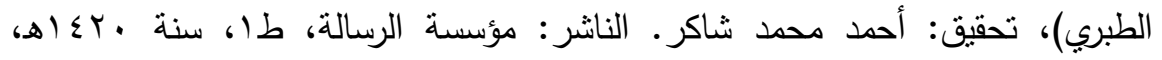

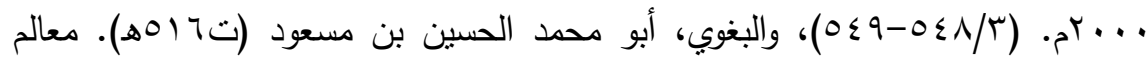
التتزيل في تفسير القرآن، تحقيق: خالد عبدالرحمن العك، دار المعرفة، بيروت، لبنان،

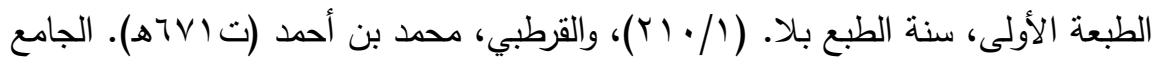

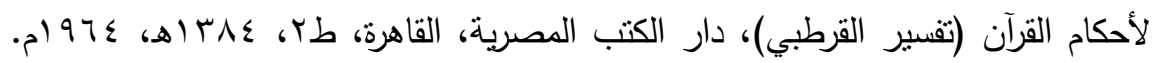

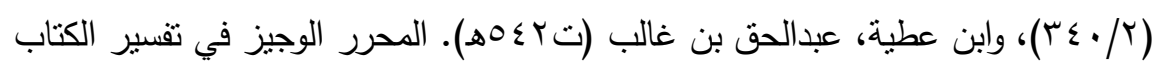

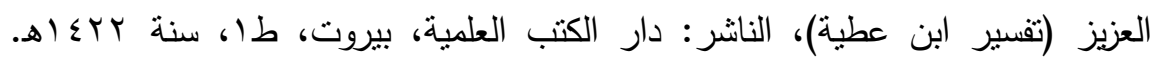

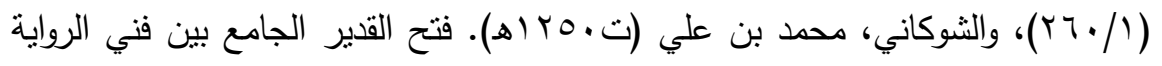

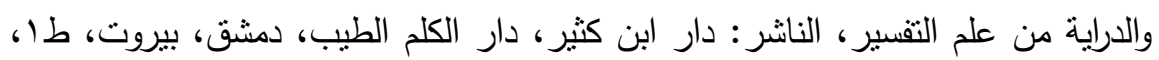

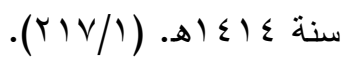
( ) الباز، عباس أحمد. المال المحرم وضوابط الانتفاع والتصرف به في الفقه الإسلامي،

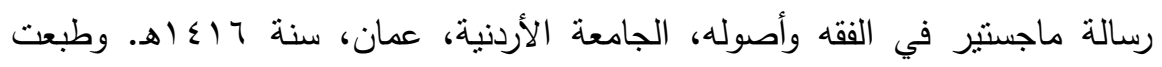

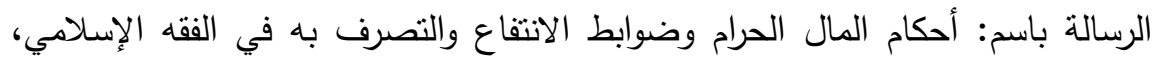

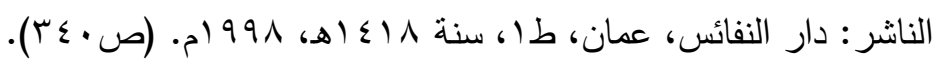




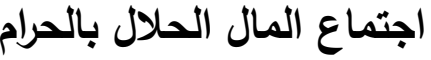

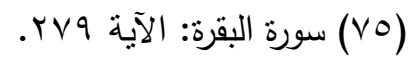

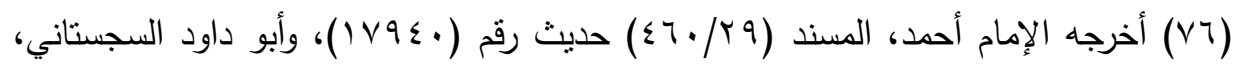

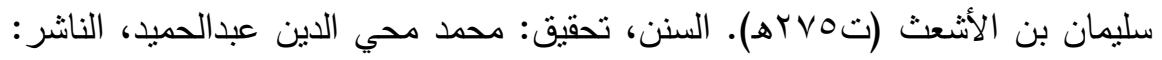

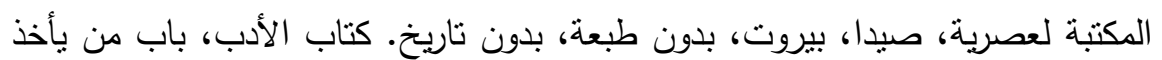

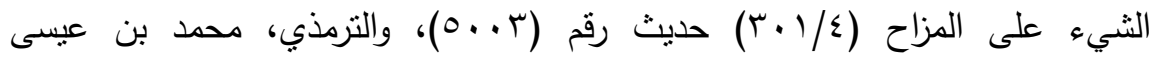

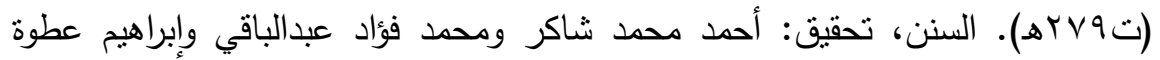

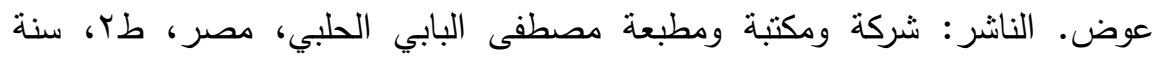

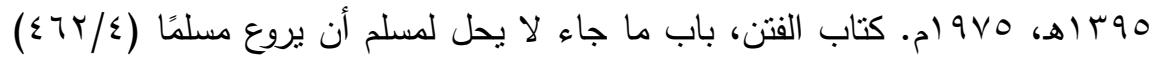

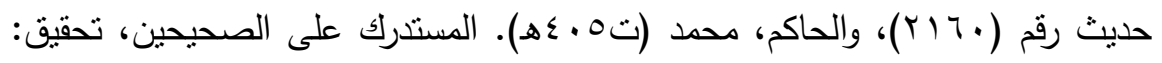

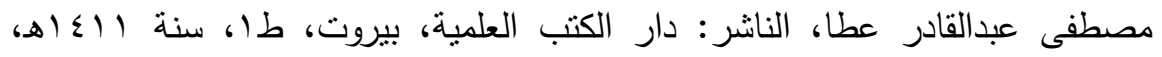

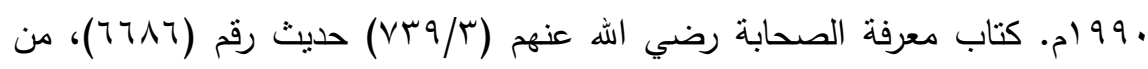

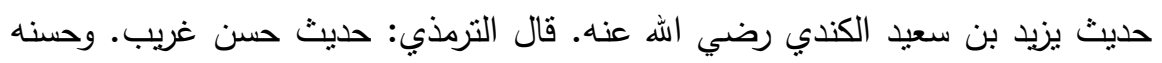
الألباني في تعليقه على سنن أبي داود.

(VV)

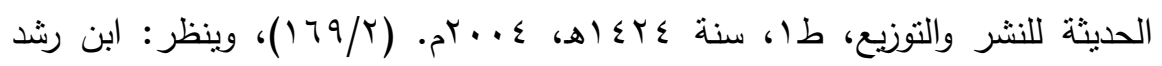

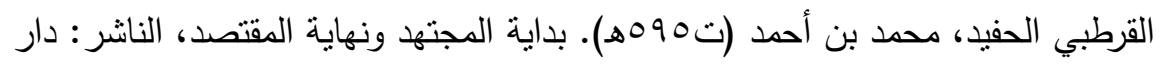

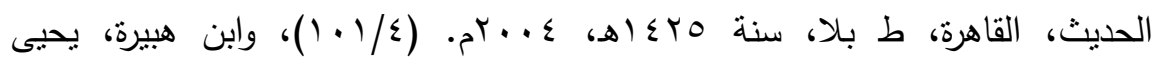

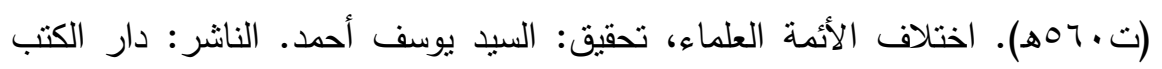

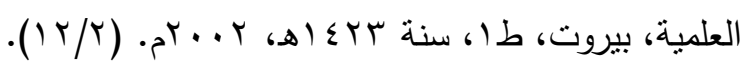

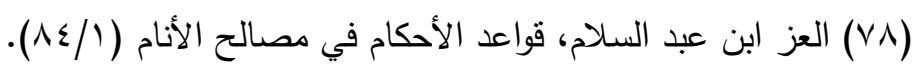

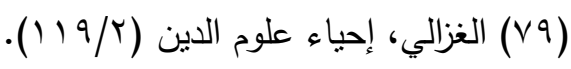

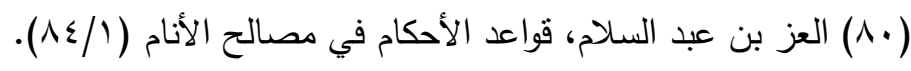

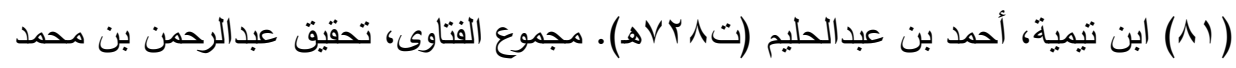
بن قاسم. نشر مجمع الملك فهز لطباعة المصحف الثريف، المدينة النبوية، المملكة

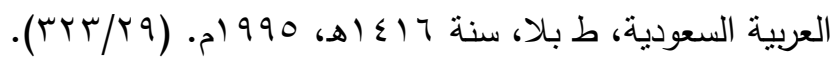


د · خالاد سالم العازمي

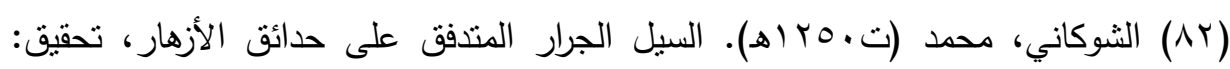

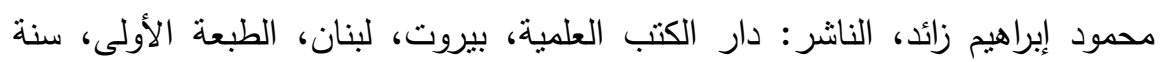

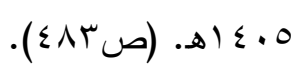
(

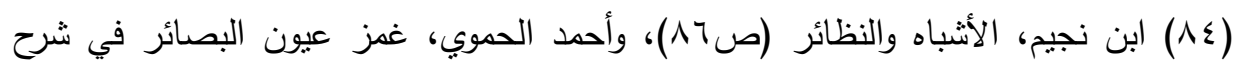

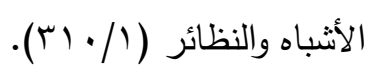

(10) الساعي، محمد نعيم، جامع القواعد والضوابط الفقهية في القضايا والوظائف العصرية،

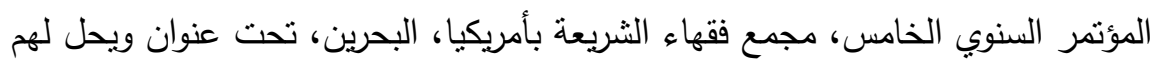

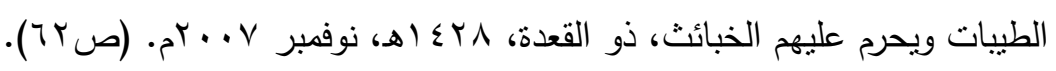

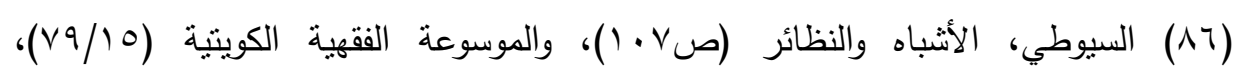

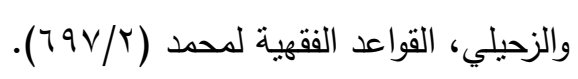

(Av)

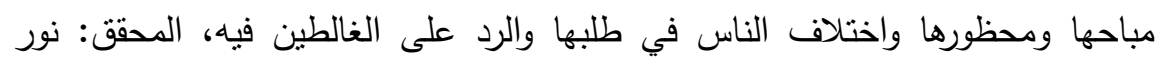

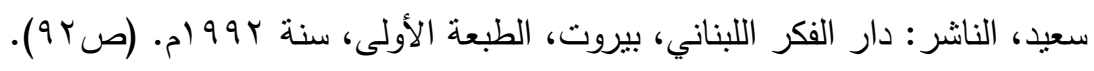

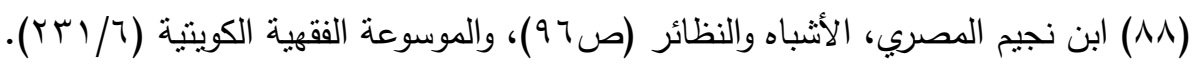

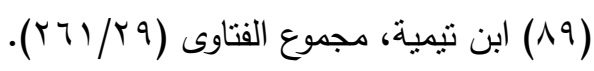

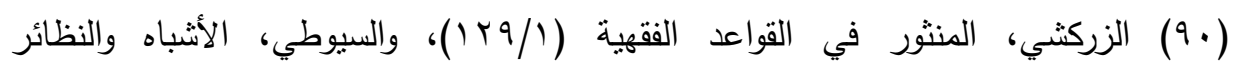
(ص) ( ) ( ) ( ) (q)

(19) ابن اللحام الدمشقي الحنبلي، علي المعروف بابن اللحام (ت . هـه). القواعد والفوائد

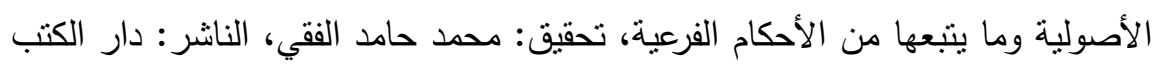

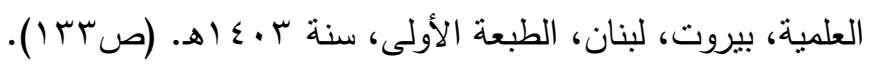

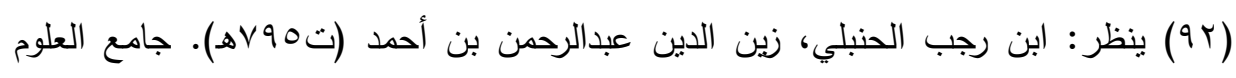
والحكم في شرح خمسين حديثا من جواهع الكلم، المحقق: شعيب الأرناؤوط وإبراهيم

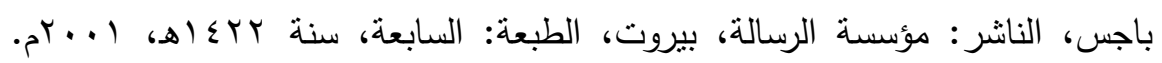

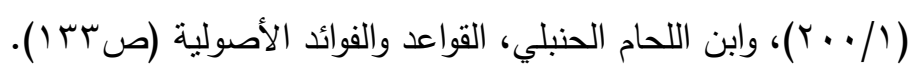

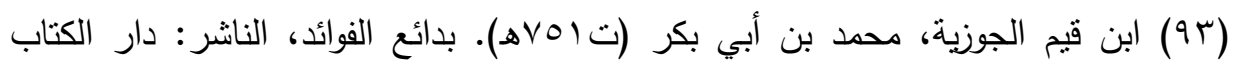
العربي، بيروت، لبنان. (r (roV/r). 


\section{=}

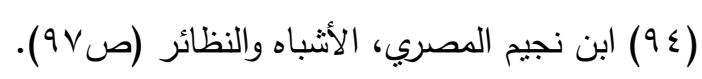

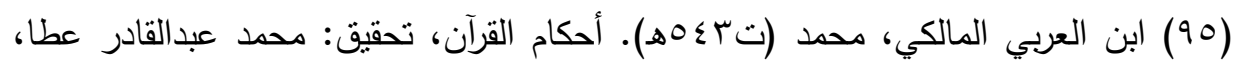

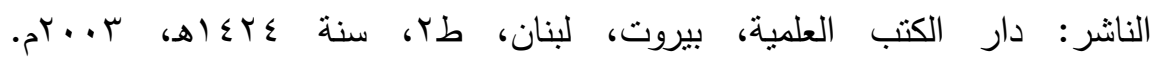

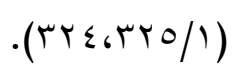

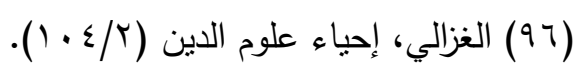

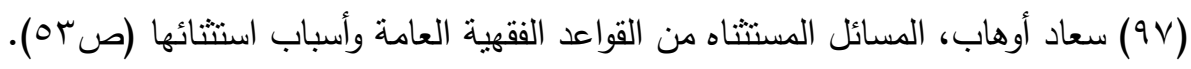

$$
\text { (9^) (9^) سورة البقرة: الآية (9V) }
$$

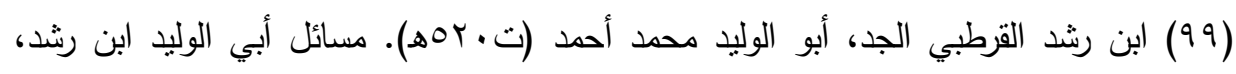

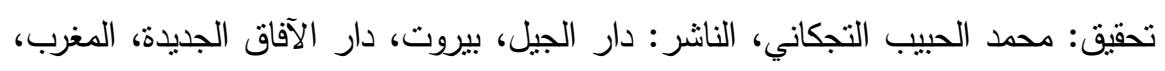

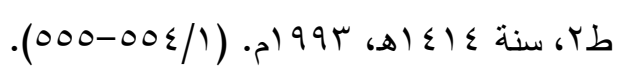

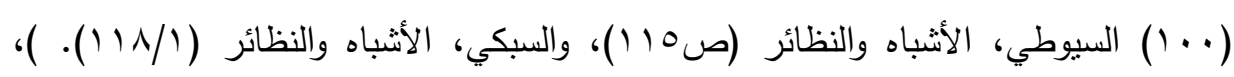

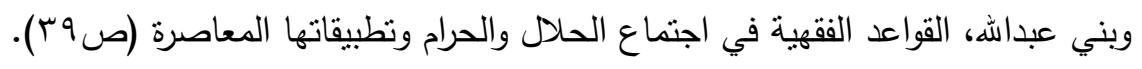

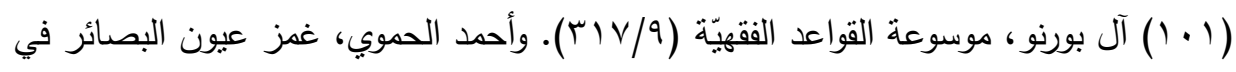

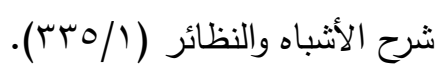

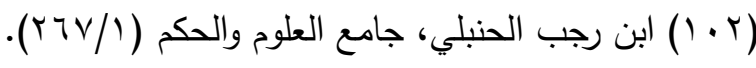

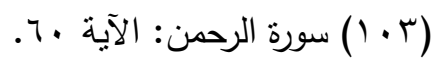

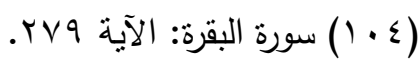

$$
\begin{aligned}
& \text { (1. (1) سورة البقرة: الآية 110. } 1 \text { الإ. }
\end{aligned}
$$

